\title{
'Een treurende monnik en een adelaar', ofwel enige opmerkingen over de bescherming van cultureel erfgoed naar Frans en Nederlands privaatrecht.
}

\section{Inleiding}

Een 'historische vergissing was hersteld', zei Jet Bussemaker, de voormalige Minister van Onderwijs, Cultuur en Wetenschappen in 2016 toen Nederland en Frankrijk gezamenlijk van Eric de Rothschild de twee portretten, 'Marten en Oopjen' hadden gekocht. ${ }^{1}$ De door Rembrandt vereeuwigde geliefden waren in 1878 door de familie Van Loon naar Frankrijk verkocht waar ze in handen waren gekomen van de bankiersfamilie De Rothschild.

De koop van de portretten à 80 miljoen euro per stuk 'werd gelegitimeerd niet vanwege het kunsthistorische, maar vanwege het nationale belang', getuige de woorden van de directeur van het Rijksmuseum, Taco Dibbits:

'Wij' mochten dit niet laten lopen. 'Wij' mochten niet langer toestaan dat 'onze' schilderijen bij een Parijse baron op de slaapkamer hingen. 'Wij' konden al helemaal niet tolereren dat ze via de veiling zouden verhuizen naar de badkamer van een potentaat in Qatar of Chongqing. 'Want', (..), 'Marten en Oopjen zijn van ons. Zij komen thuis.' De twee geportretteerden horen bij ons, (..), omdat zij toonbeelden van 'ambitie' zijn, omdat zij uitdragen hoezeer 'de wereld aan hun voeten lag', zoals voor veel zeventiende-eeuwse Amsterdammers - 'het New York van die tijd' - de wereld open lag., ${ }^{2}$

Dat de overheid kunst moet beschermen was in de negentiende eeuw al gepropageerd door Victor de Stuers. De Stuers was advocaat en Tweede Kamerlid, maar bovenal kunstliefhebber. In zijn artikel getiteld 'Holland op zijn smalst' uitte hij grote zorgen over de behandeling van het cultuurgoed in Nederland. ${ }^{3}$ Hij bekritiseerde Thorbecke, die in een Kamerdebat ooit had opgemerkt dat kunst 'geen regeringszaak' was. ${ }^{4}$ De Stuers pleitte voor een verregaande overheidsbemoeienis ter bescherming van het Nederlandse cultuurgoed dat totaal verloren dreigde te gaan als de overheid niet ingreep.

Met de huidige Erfgoedwet van 2016, die onder andere moet voorkomen dat belangrijke

$1 \quad$ K. Kleijn, Marten en Oopjen zijn weer thuis, in: De groene Amsterdammer, nr 28-29, 13 juli 2016.

2 Citaat is overgenomen van Kleijn, noot 1.

3 V. de Stuers, Holland op zijn smalst, in: De Gids, nr 37, 1873, p. 320-403, 327/373. Hij schreef het artikel als reactie op een debat in de Tweede Kamer op 4 december 1872 over 'de afdeeling Kunsten en Wetenschappen'. De verwachting die na dit debat bij velen was gewekt dat voortaan in Nederland de monumenten 'onzer kunst en onzer historie' waren gered, deelde hij allerminst.

4 Handelingen Tweede Kamer 1862-63, p. 272. Ik kom hier in de slotopmerkingen nog op terug. Overgenomen uit: W. Oosterbaan-Martinius, Schoonheid, welzijn, kwaliteit. Kunstbeleid en verantwoording na 1945, Den Haag 1990, p. 86-87. 


\section{VAN DER VEN, F.A.J.}

kunstwerken, die vaak eigendom zijn van particulieren, naar het buitenland verdwijnen, heeft de Minister van Onderwijs, Cultuur en Wetenschap een behoorlijke vinger in de pap van het kunstwereldje gekregen. De Minister kan een kunstobject 'aanwijzen', waarmee het een beschermde status krijgt. $^{5}$ Deze aanwijzing kan zowel particulier- als openbaar kunstbezit betreffen. De aanwijzing legt het eigendomsrecht aan banden. Zo is vervreemding aan strikte regels gebonden en speelt de overheid bij de vervreemding een grote rol. Was de Minister tot nu toe terughoudend als het op aanwijzen aankwam, de commissie Pechtold heeft de Minister in september 2019 geadviseerd het aanwijzingsbe le id te verruimen. ${ }^{6}$ Aanleiding tot het instellen van de commissie was de verkoop van een belangrijke tekening van Rubens door Prinses Christina. De tekening stond niet op de lijst van beschermde cultuurgoederen en was een maand eerder geveild. Nederlandse musea wilden de tekening maar al te graag kopen, maar hadden het nakijken toen een buitenla ndse partij zeven komma twee miljoen euro bood.

Van een commissie komt doorgaans een commissie: op advies van de commissie Pechtold is een commissie aan de slag gegaan die duidelijke aanwijzingscriteria moet opstellen en die het register van beschermde cultuurgoederen en verzamelingen moet 'actualiseren'.? Simpel gezegd moet die commissie uitzoeken wat particulieren zoal aan de muur hebben hangen. In het advies van Pechtold lezen we verder dat de belastingdienst een speciaal team in huis heeft dat zich bezig houdt met het zogeheten programma 'Zeer Vermogende Personen' en dat aan dit team een lid met kennis van de culturele sector en de Erfgoedwet zou moeten worden toegevoegd. ${ }^{8}$ Het moge duidelijk zijn waarom. ${ }^{9}$

Ik vraag mij af of de huidige overheidsbemoeienis als gevolg van de Erfgoedwet en het advies van Pechtold niet te ver zal doorslaan en de eigendom van de particulier te veel aan banden legt. Eigendom is volgens de definitie in artikel 5:1 BW immers 'het meest omvattende recht dat een persoon op een zaak kan hebben'. Waarom zou de eigenaar bij wijze van spreken niet een potje dart op zijn Rembrandt mogen spelen? ${ }^{10}$ Of zijn Van Gogh

$5 \quad$ Hieronder, bij de inhoudelijke behandeling van de Erfgoedwet noem ik de specifieke wetsartikelen.

6 Advies bescherming cultuurgoederen 'Van terughoudend naar betrokken', rapport commissie Pechtold, 30-9-2019, www.raadvoorcultuur.nl, p. 61-62.

7 'Van terughoudend naar betrokken', rapport commissie Pechtold, noot 6, p. 59.

'Van terughoudend naar betrokken', rapport commissie Pechtold, noot 6, p. 60.

9 De 'zeer vermogende personen' kunnen zich verheugen in speciale aandacht van de belastingdienst. De website van het Ministerie van Financiën noemt als voorbeeld mensen met familiebedrijven, dotcommiljonairs, profvoetballers en bekende Nederlanders. Volgens de website hebben ze vaak zowel in binnen- als buitenland geld en bezittingen 'variërend van verschillende bv's en aandelenportefeuilles tot luxe zeiljachten, villa's, landgoederen, een kunstverzameling of een eigen museum'. 'Het is belangrijk dat wij deze groep goed in beeld hebben', aldus de programmamanager 'Zeer Vermogende Personen.' 'Daardoor zijn wij een goede gesprekspartner voor hen bij ingewikkelde belastingvraagstukken, maar we kunnen ook snel ingrijpen als dingen niet goed gaan.' De belastingdienst zou de belastingdienst niet zijn als het mes niet aan twee kanten snijdt. belastingdienst.n1/specialeaandacht-voor-zeer-vermogende-personen.

10 J.L. Sax, Playing Darts with a Rembrandt, Public and Private Rights in Cultural Treasures, Michigan 1999. A.F. Salomons, De genade en ongenade van den eigenaar. Omvat het eigendomsrecht de 


\section{EEN TREURENDE MONNIK EN EEN ADELAAR}

meenemen in het graf zoals de Japanner Ryoei Saito ooit van plan was? ${ }^{11}$

In de diverse rapporten over kunstbescherming wordt vaak gewezen naar Frankrijk dat een lange traditie kent als het aankomt op het beschermen van kunst van nationaal belang. Tot 2004 was de wetgeving met betrekking tot cultureel erfgoed in Frankrijk nogal versnipperd en onoverzichtelijk. ${ }^{12}$ Er bestonden talrijke wetten die in genoemd jaar met de invoering van de Code du patrimoine tot één duidelijke wet zijn gesmeed. ${ }^{13}$ Deze Code is het pendant van onze erfgoedwet.

Als voorbeeld van de bescherming van kunst in Frankrijk bespreek ik twee Franse rechtszaken die onlangs werden uitgevochten voor de hoogste rechter. In beide zaken claimde zowel de Staat als een privépersoon eigenaar te zijn van een cultuurgoed dat voor Frankrijk grote nationale betekenis had. De uitspraak van de rechters over de eigendom werd sterk beïnvloed en ingegeven door de gedachte dat de betreffende cultuurgoederen voor Frankrijk behouden moesten blijven, en niet via een veiling naar het buitenland zouden verdwijnen.

Ik behandel de twee casus, waarin de verjaring en derdenbescherming een belangrijke rol spelen, eveneens naar Nederlands recht. In ons Burgerlijk Wetboek zijn specifieke regels opgenomen voor de verjaring en derdenbescherming van cultuurgoederen die op grond van de Erfgoedwet zijn aangewezen. Daarentegen heeft Frankrijk met de Code du patrimoine en de Code général de la propriété des personnes publiques specifieke wetten die op het gebied van genoemde leerstukken derogeren aan de Code civil. ${ }^{14}$

We zullen eveneens zien dat de Franse overheid met de Code du patrimoine een instrument in handen heeft waarmee het een fluitje van een cent is de deur naar het buitenland voor cultureel privé-eigendom hermetisch te sluiten.

bevoegdheid om eigen cultuurgoederen te vernietigen? Een pleidooi voor aanpassing van de wet tot Behoud van Cultuurgoederen, Amsterdam 2002.

11 Saito kocht in 1990 op een veiling bij Christie's en Sotheby's in New York het 'Portrait de dr Gachet' geschilderd door Van Gogh en 'Bal du moulin de la Galette' geschilderd door Renoir, voor de lieve som van honderdenzestig miljoen dollar. Zes jaar later stierf hij. Na zijn dood probeerde het Metropolitan Museum of Art de werken te traceren. Tevergeefs. Meteen deed in kunstkringen het gerucht de ronde dat hij de twee schilderijen had laten mee-cremeren omdat hij ooit had gezegd dat hij dat van plan was omdat hij zijn kinderen niet wilde opzadelen met een enorme som erfbelasting. Later bleek dat zijn kinderen de schilderijen aan een particulier hadden verkocht.

12 J. Chatelain, F. Chatelain, Oeuvres d'art et objets de collection en droit Français, Parijs 1990. J-F. Poli, La protection des biens culturels meubles, Parijs 1996; G. Carducci, La restitution internationale des biens culturels et des objets d'arts, Parijs 1997.

13 De inhoud van de oude wetten is grotendeels letterlijk overgenomen. J. El-Bitar, Der deutsche und der französische Kulturgüterschutz nach der Umsetzung der Kulturgüterrückgabegesetz der Kulturgüterrückgaberichtlinie, in: Studien zumvergleichenden undinternationalen Recht, 144, Frankfurt am Main, 2007, 70.

14 In de Code du patromoine is geen algemene bepaling te vinden die iets zegt over derogatie van de Code du patrimoine aan de Code civil; wel bepaalt de Code du patrimoine in specifieke gevallen dat de Code civil niet geldt. 


\section{VAN DER VEN, F.A.J.}

\section{Casus eerste zaak. Pleurant No 17.}

\section{Inleiding}

We schrijven Parijs oktober 2014. Drie dames begeven zich naar de Avenue d'Iéna, waar het veilinghuis Pierre Bergé \& Associés gevestigd is. Het zijn zussen uit een kunstminnende familie. Hun overgrootvader was kunstverzamelaar en had in 1813 een middeleeuws beeld gekocht, dat sindsdien in de familie was gebleven en door erfopvolging op de zussen was overgegaan. Zoals vaak het geval is met verzamelaars, staat het huis vol met kunst, maar zijn er niet genoeg contanten om de erfbelasting te betalen. De fiscus was dan ook de reden dat ze de gang naar het veilinghuis maakten. De gezusters en het veilinghuis kwamen overeen dat het veertig centimeter hoge beeld op 17 december zou worden geveild. Het beeld werd in de veilingcatalogus opgenomen.

Omdat het veilinghuis vermoedde dat het beeld wel eens zou kunnen worden gekocht door een buitenlandse verzamelaar en dus uit Frankrijk zou verdwijnen, verzocht het conform de regels van de Code du patrimoine de Minister van Cultuur om een uitvoercertificaat. De Minister liet al snel weten dat hii een dergelijk certificaat weigerde af te geven. En dat niet alleen, namens de Staat vorderde hii met de revindicatie het beeld op omdat hii van mening was dat het tot het publiek domein van de Staat behoorde. Het geschil werd uitgevochten voor de administratieve rechter. De Staat kreeg in drie instanties het gelijk aan zijn zij.

Het was niet alleen een beeld met een grote historische waarde, maar er hing natuurlijk ook een aardig prijskaartje aan. Op het internet kwam ik in een artikel een geschatte waarde van twee miljoen euro tegen. ${ }^{15}$ De vraag die zich bij lezing van de uitspraak opdringt is waarom de administratieve rechter zomaar kon oordelen over de eigendomsvraag. Met andere woorden waarom de Staat niet de gang naar de burgerlijke rechter had gemaakt? En in het bijzonder de vraag of er voor de zussen geen argument te bedenken was geweest om aan te tonen, dat niet de Staat, maar zii eigenaar van het beeld waren. Deze laatste vraag is, nu de rechter heeft gesproken, misschien een theoretische vraag, maar wel aardig genoeg om te beantwoorden, al was het alleen maar omdat het beeld zo'n mooie, roerige geschiedenis heeft, die begint met de dood van Philips de Stoute.

\section{De graftombe van Filips de Stoute in Champmol ${ }^{16}$}

Het is 16 april 1404. Philips de Stoute, hertog van Bourgondië, graaf van Vlaanderen, Artesië, Réthel en Nevers en heer van Mechelen en Salins, was net gearriveerd in Brussel, de hoofdstad van Brabant, toen hij na het banket ziek werd. Hij was besmet geraakt door een griep die in Brabant rondwaarde. Zijn toestand verslechterde snel en hij wilde terug

15 Le moine pleurant peut sécher ses larmes, in: Veille juridique sur les droits de l'homme et les libertés publiques, 24 juni 2018.

16 De gegevens overde Philips de Stoute zijn grotendeels ontleend aan: Rik Wouters, Philips de Stoute en zijn drie begraafplaatsen, Historiek.net, 2018; S.C.M. Lindquist, Agency, Visuality and Society at the Chartreuse de Champmol, 2008. 


\section{EEN TREURENDE MONNIK EN EEN ADELAAR}

naar zijn paleis in Dijon. Er werd voor de reis een speciaal bed ontworpen. Van intensive care was geen sprake: Philips had zijn hoop gevestigd op de heilige Maria en liet zich daartoe vanuit Brussel eerst vervoeren naar Halle, ten zuidoosten van Brussel, waar een beeld van een zwarte maagd vereerd werd. De tocht naar Maria mocht niet baten. De volgende dag stierf hij. Hij had begraven kunnen worden in de kathedraal van Saint-Denis, ten noorden van Parijs, omdat hij de zoon was van de Franse koning en de Franse prinsen daar hun laatste rustplaats kregen. Maar Philips' wens was te worden bijgezet in Dijon. Zijn hart was er, zoals te doen gebruikelijk in die tijd, meteen uitgehaald. Het hart bevatte de ziel, zo was de gedachte, en werd wel in Saint Denis begraven. De tocht naar Dijon zou zeven weken duren. Op 1 mei vertrok de rouwstoet via Geraardsbergen, Arras en Cambrai naar Dijon waar hij werd bijgezet in de graftombe in het Kartuizerklooster te Champmol ten westen van Dijon. Dit klooster, dat hij in 1377 zelf had gesticht, was bestemd als mausoleum voor de leden van het Huis Valois waartoe hij behoorde. In 1381 had Philips opdracht gegeven aan zijn hofbeeldhouwer Jean de Marville een praalgraf of graftombe te maken. Later kreeg De Marville hulp van de Hollanders Claus Sluter uit Haarlem en diens neef Claus de Werve uit Hattem. ${ }^{17}$

De graftombe bevond zich in het koor van de kloosterkerk. Later kwam er een tweede graftombe bij waarin Philips' vrouw Margarethe van Beieren, die in 1405 stierf, en hun beider zoon en opvolger van Philips, Jan zonder Vrees, hun laatste rustplaats vonden. Jan zonder Vrees werd in 1419 vermoord. De graftombes zijn omringd door tweeëntachtig beeldjes. Over een van deze beeldjes, Pleurant No 17, die het graf van Philips sierde, gaat ons geschil.

\section{Pleurants $^{18}$}

De marmeren graftombe van Philips is ongeveer een meter dertig hoog en is bedekt door een plaat met daarop een zogeheten gisant, een liggende figuur die de dode Philips moet voorstellen. De beeldjes die de graftombe omringen zijn geplaatst in nissen onder gotische spitsbogen in de zijwanden van de praalgraven. Deze vrijstaande beeldjes, ongeveer veertig centimeter hoog en gemaakt van albast, worden Pleurants genoemd. Een Pleurant is letterlijk vertaald iemand die huilt of treurt. De Pleurants vormen een 'stoet' van rouwende figuren die treuren om het heengaan van Philips, of zoals Johan Huizinga deze beeldjes mooi beschreef: 'de diepste en waardigste verbeelding van de rouw, een

17 Over de vraag of 'Claus de Werve van Hathein', die 39 beeldjes heeft gemaakt, werkelijk uit Hattem komt zijn de geleerden het niet eens. M. Koenen, Klaas Sluter, in: Dietsche Warande en Belfort, 1941, 178-186, 185.

18 Literatuur over de Pleurants: M. Pierre Quarré, Les Pleurants des cortèges funèbres des ducs de Bourgogne se mouchaient-ils dans leurs doigts?; Idem, Les Pleurants des tombeaux des ducs de Bourgogne à Dijon, in: Bulletin de la Société nationale des Antiquaires de France Année, 1948-1949, Parijs 1952, p. 124-132; Idem, Les tombeaux démembrés dans la sculpture Française, in: An illustrated inventory offamous dismembered works of art European painting with a section on dismembered tombs in France, Paris 1974, 210-220. 


\section{VAN DER VEN, F.A.J.}

dodenmars in steen'. ${ }^{19}$ De traditie van dergelijke rouwende figuren ontstond in de dertiende eeuw. Vaak zijn het anonieme monniken, maar soms ook worden familieleden van de overledene uitgebeeld, misschien ter herinnering aan de daadwerkelijke begrafenis. ${ }^{20} \mathrm{De}$ hierboven genoemde beeldhouwers individualiseerden de beeldjes, die ieder op eigen wijze hun verdriet tonen. De een schreeuwt het uit of richt zijn ogen ten hemel, de ander slaat de handen voor het gezicht of houdt z'n hoofd verscholen in de capuchon van zijn pij. De gedetailleerde sculpturen kunnen worden beschouwd als individuele kunstwerken. In de zestiende en zeventiende eeuw verdween de praktijk van het plaatsen van dergelijke figuren.

\section{Revolutie en de inbeslagname van Pleurant No 17}

We gaan naar $1789 .{ }^{21}$ Op 17 juni van dat jaar riep de Derde Stand zich uit tot de Assemblée nationale. Koning Lodewijk XVI sloot daarop de vergaderzaal. Drie dagen later vertrok de Assemblée onder leiding van Mirabeau naar de Kaatsbaan en zwoer de eed niet eerder uiteen te gaan dan wanneer er een Grondwet was. Een deel van de geestelijkheid en de adel sloten zich aan. Begin juli veranderde de Assemblée nationale zijn naam in Assemblée constituante. Op 14 juli vond de bestorming van de Bastille plaats. Afbeeldingen doen altijd geloven dat de bestorming gepaard ging met enorm tumult, vuurwerk en krachtpatserij, maar in werkelijkheid zaten er maar zeven gevangenen achter slot en grendel en in het dagboek van de koning die op het moment van de 'bestorming' op jacht was, lezen we op 14 juli slechts één woord: 'rien', waarmee hij aangaf die dag niets geschoten te hebben. Toen hij aan de hertog De la Rochefoucauld zijn beroemde vraag stelde: 'Is het een revolte?', antwoordde deze: 'Nee, sire, het is geen revolte, c'est une revolution.' ${ }^{22}$

Nadat op 4 augustus 1789 de Déclaration des droits de l'homme et du citoyen was opgesteld, trad op 1 oktober 1791 de Grondwet in werking. Frankrijk was vanaf die dag een constitutionele monarchie die twee jaar later met de dood van Lodewijk in zijn nieuwe gedaante van 'citoyen Louis Capet' onder de guillotine zou eindigen. Intussen had de Assemblée constituante niet stilgezeten. Omdat het land in een financiële crisis verkeerde had de Assemblée bij wet van 2 november 1789 op voorstel van Talleyrand, bisschop van Autun, beslag gelegd op alle kerkelijke goederen. ${ }^{23}$ De goederen werden ter beschikking

19 J. Huizinga, Herfsttij der middeleeuwen. Studie over levens- en gedachtenvormen der veertiende en vijftiende eeuw in Frankrijk en de Nederlanden. Bezorging tekst en illustraties Anton van der Lem, Leiden 2018, 281. Zie ook: Stendhal, Mémoires d'un touriste, I, Parijs 1854, p. 74

20 Bijvoorbeeld bij de graftombe in Westminster Abbey van Lady Burghley en haar dochter Anne. Bij die tombe zijn in de beeltenissen van de 'Weepers' duidelijk Lady Burghley's echtgenoot, haar zoon en de drie dochters van Anne te herkennen.

21 S. Schama, Een kroniek van de Franse revolutie, 2002; B. Verheijen, Geschiedenis onder de guillotine, Twee eeuwen geschiedschrijving van de Franse Revolutie, Amsterdam 2013; J.H.A. Lokin, W.J. Zwalve, C.J.H. Jansen, Hoofdstukken uit de Europese Codificatiegeschiedenis, Den Haag 2020, 222 v.

22 Volkskrant, 1 februari 2011.

23 Talleyrand sloot zich in 1789 aan bij de Nationale Grondwetgevende Vergadering. Toen hij als eerste geestelijke van katholieke huize in 1791 de Grondwet ondertekende werd hij door de Paus geëxcommuniceerd. De opbrengst van de goederen waar beslag op was gelegd konden volgens hem gebruikt worden om het salaris van priesters en onderwijzers te betalen en liefdadigheidsinstellingen te 


\section{EEN TREURENDE MONNIK EN EEN ADELAAR}

gesteld van de Nation. ${ }^{24}$ De eigendomsovergang op de Staat geschiedde automatisch krachtens de wet. Het was derhalve een originaire wijze van eigendomsverkriiging. De eigendom ging van rechtswege onvoorwaardelijk en volledig over op de Staat, zonder dat was vastgesteld dat de voormalige eigenaar ook aanspraak kon maken op een in redelijke mate vastgestelde schadevergoeding. Hoewel er mooie juridische termen zoals 'nationalisatie' voor werden gebezigd ${ }^{25}$ kwam het erop neer dat de kerkelijke goederen werden geconfisqueerd. In het volkenrecht wordt confiscatie gedefinieerd als onteigening zonder schadevergoeding. ${ }^{26}$ Het is in beslagname zonder recht of titel, kortom: roof. Ongeveer tien procent van het Franse grondgebied wisselde van eigenaar.

Op deze wijze kwam dus ook het klooster te Champmol en dientengevolge het grafmonument van Philips de Stoute met de 'wenende monniken', ter beschikking van de Staat. Bij decreet van 9 juli 1790 besloot de Assemblée dat de kerkelijke goederen mochten worden verkocht. De Kartuizers vertrokken. Een wet van 4 mei 1791 formaliseerde de verkoop van de goederen van het klooster te Champmol. Het klooster werd tien dagen na het vertrek van de monniken verkocht aan Emmanuel Crétet, die later minister zou worden in de regering van Napoleon I. Hij bouwde Champmol om tot luxueus buitenverblijf. Het klooster liet hij grotendeels verder afbreken; het hoofdportaal en de zogeheten Mozesput zijn gespaard. Op de plek van het klooster staat nu een ziekenhuis.

De graftombes van de hertogen van Bourgondië, inclusief de Pleurants, werden uitdrukkelijk van verkoop uitgesloten. Zij bleven daarmee in het publieke domein. Daarop werden de graftombes en de tweeëntachtig albasten beelden gedemonteerd en opnieuw geplaatst in de kerk van Sainte-Bénigne te Dijon, die op 30 juli 1792 als kathedraal werd ingewijd. Tijdens de Terreur, beval de Nationale Conventie bij decreet van 1 augustus 1793 tot de vernietiging van de koninklijke beeltenissen. De gemeenteraad van Dijon besloot op 8 augustus 1793 dat alleen de gisants, de liggende figuren op de graftombes, die Philips, zijn vrouw en zijn zoon voorstelden, zouden worden vernietigd, maar dat de kleine beelden die de graftombes omringden zouden worden gespaard en op een geschikte plek zouden

onderhouden. De motivering van de inbeslagneming van de goederen was dat de zojuist genoemde kosten voortaan door de overheid zouden worden betaald. C. Brinton, The lives of Talleyrand, New York 1963.

$241^{\circ}$ Que tous les biens ecclésiastiques sont à la disposition de la nation, à la charge de pourvoir, d'une manière convenable, aux frais du culte, à l'entretien de ses ministres, et au soulagement des pauvres, sous la surveillance et d'après les instructions des provinces; $2^{\circ}$ Que dans les dispositions à faire pour subvenir à l'entretien des ministres de la religion, il ne pourra être assuré à la dotation d'aucune cure moins de 1200 livres par an, non compris le logement et les jardins en dépendant. Archives Parlementaires de 1787 à 1860, eerste serie (1787-1799) deel IX - 16 september-11 november 1789, Parijs 1877, 649.

25 Bv. de uitspraak van de appèlrechter, noot 36: 'le décret de l'Assemblée constituante du 2 novembre 1789 portant sur la nationalisation des biens du clergé.'

26 Volkenrechtgeleerde Seidl-Hohenveldern definieert confiscatie als volgt: '(..) jeder Hoheitskraft (..), kraft dessen eine de jure oder de facto anerkannte Regierung oder eine zumindest indirekt anerkannte Machthaber einen Eigentumstitel an einer Sache oder einem Recht kraft seines Hoheitsrechtes erwirbt oder zu erwerben beansprucht, ohne den bisherigen Eigentümer dieser Sache oder dieses Rechtes hierfür in gerechtem Maße zu entschädigen.' I. Seidl-Hohenveldern, Internationales Konfiskations und Enteignungsrecht, Berlijn en Tübingen 1952, 5. 


\section{VAN DER VEN, F.A.J.}

worden bewaard. De vernietigingsmaatregelen betroffen volgens de gemeenteraad alleen de symbolen van het oude regime en niet de albasten beelden die rond de tombes waren geplaatst. Uit de notulen van de vergadering van 25 maart 1794 van de tijdelijke kunstcommissie blijkt dat de graven van de voormalige hertogen van Bourgondië grondig verminkt waren en dat, hoewel het erg moeilijk was geweest ze te redden, de kleine albasten figuren het hadden overleefd.

Kunstverzamelaar Louis Bénigne Baudot (1765-1844) schreef in zijn historische notitie over Dijon dat de kleine Kartuizers die het massief omringden, aanvankelijk bewaard waren in een winkel. En verder dat tijdens de verhuizing, maar in ieder geval na 8 augustus 1793, verschillende beelden waren gestolen en dat er ten minste één persoon om deze reden was veroordeeld tot gevangenisstraf. ${ }^{27}$ Een inventaris uit 1794 maakt melding van zeventig beelden die bewaard werden in de kerk van Sainte-Bénigne te Dijon. In 1799 werden ze in het museum van Dijon tentoongesteld. ${ }^{28}$ In de ontbrekende twaalf zou op de kunstmarkt levendig worden gehandeld. Dat geldt ook voor 'ons' beeld.

\section{De zoektocht naar de Pleurants ${ }^{29}$}

In 1819 begon de architect Claude Saint-Père met de restauratie van de graftombes. Hij ging op zoek naar de ontbrekende twaalf beelden. Hij kon er twee kopen van een zekere M. de Saint Thomas, die ze op zijn beurt gekocht had van de genoemde kunstverzamelaar LouisBénigne Baudot. De architect liet de tien ontbrekende beelden namaken. In 1827 werd de gerestaureerde graftombe onthuld. Hoe Baudot aan de twee beelden was gekomen is onduidelijk. Wel staat vast dat Baudot er in 1811 nog eentje had weten te bemachtigen. Hij verkocht dit beeld in 1813 aan zijn neef M. Perret-Carnot, de overgrootvader van onze drie gezusters. Dit beeld is Pleurant No 17, dat twee eeuwen in het bezit van de familie PerretCarnot bleef, totdat de Staat het beeld in 2014 opeiste.

Het zij hier alvast opgemerkt dat het opmerkelijk is dat de zoektocht van de restaurateur via M. de Saint Thomas en Baudot niet heeft geleid naar Perret-Carnot. Heeft Baudot de verkoop aan zijn neef Perret-Carnot voor de restaurateur willen verzwijgen? In 1827 ontbraken er bii de onthulling van de graftombe dus tien originele beelden. Pas veel later zouden er nog een paar opduiken. In 1945 gaf het Louvre een beeld terug, waarvan niemand wist hoe het daar terecht was gekomen, en het Muséé de Cluny restitueerde er twee. Een van deze twee had het museum in 1861 weten te bemachtigen van de Schotse Duke of Hamilton.

27 Louis-Bénigne Baudot, Notes historiques et archéologiques sur Dijon, prises pour la plupart sur les objets mêmes, depuis la Révolution de 1789, Catalogue de la collection de manuscrits de la Bibliothèque municipale de Dijon, no 325, Ms 1600-1610, 1602.

28 Louis-Bénigne Baudot, noot 27.

29 M. Andrieu, Les tombeaux des ducs de Bourgogne au Musée de Dijon. Histoire des Pleurants, in: Bulletin Monumental, 1933, 92-2, 171-193; H. Chabeuf, Les Pleurants des tombeaux des Ducs de Bourgogne, Bulletin des Musées de France, 1910, 3, 43-45; idem, Le pleurant de la collection PerretCarnot, in: Mémoires de la Commission des Antiquités du departement de la Côte-d'Or, 17, 1915-1916, $147-150$. 


\section{EEN TREURENDE MONNIK EN EEN ADELAAR}

De drie beelden werden toegevoegd aan de graftombe te Dijon. Er zijn in totaal vijfenzeventig originelen. Er ontbreken in Dijon dus nog zeven. Twee van de zeven zijn nog nooit ergens ontdekt. Verder is er het litigieuze beeld Pleurant No 17. En vier staan er tegenwoordig in het museum in Cleveland. Deze vier beelden doken in 1867 op bij een handelaar in Nancy. De conservator van het Museum in Dijon deed een vergeefse poging ze te kopen. Uiteindelijk kwamen de beelden in 1922 in handen van een rijke Amerikaan, Clarence Mackay, uit Ohio.

Dat de beelden in eigendom aan een Amerikaan toebehoorden was weliswaar een doorn in het oog voor de Fransen, maar ze stonden niet, zoals nu, meteen met een advocaat bij Mackay op de stoep om de beelden op te eisen. We lezen in een krantenartikel uit 1958 dat Franse overheidsambtenaren uit Dijon en Parijs zeer voorzichtig waren geweest en elk commentaar wilden vermijden dat als kritiek op Amerikaanse verzamelaars zou kunnen worden uitgelegd. Mackay had de beelden op de openbare markt gekocht en er een aanzienlijk bedrag voor betaald. Het was volgens de ambtenaren 'a perfectly legitimate deal' geweest. ${ }^{30}$ Wel hadden ze Mackay er in 1932 al op gewezen dat hij in het bezit was van een voor Frankrijk nationale schat. Mackay zou hebben geantwoord dat de beelden echter noo it uit zijn collectie zouden verdwijnen. Na zijn dood in 1940 verkochten zijn erven twee beelden aan het Museum van Cleveland en de andere twee aan Leonard C. Hanna, die ze uiteindelijk aan het museum van Cleveland legateerde. ${ }^{31}$ Een poging van de Franse overheid om ze van dit museum te kopen mislukte. De museumdirecteur liet in 1959 replica's maken van de vier 'Amerikaanse' Pleurants. Hii schonk de replica's aan het museum in Dijon. De twee tombes zijn tegenwoordig in volle glorie te bezichtigen in het museum van Dijon, dat gevestigd is in het paleis van de hertogen van Bourgondië.

Pleurant No 17 kwam dus in 1813 via genoemde Baudot door koop terecht in handen van de overgrootvader van de drie zussen. Zoals gezegd had Baudot in totaal drie Pleurants weten te bemachtigen en blijft het onduidelijk van wie Baudot in 1811 No 17 had verkregen. Had hij het beeld gekocht van de Bertholomey, een antiquair in Dijon, van wie vast stond dat hij er ooit tien had gehad? Of behoorde het tot de groep Pleurants die na 8 augustus 1793 was gestolen? Of tot de groep die in het museum van Dijon waren tentoongesteld? Het blijft allemaal even schimmig.

Baudot was afkomstig uit een erudiete Bourgondische familie. Hij was conservator van de Bibliotheek te Dijon en 'Président de commission des antiquités de la Côte d'or'.32 Bovenal toonde hij zich een verwoed kunstverzamelaar. Hij was dus iemand die dicht bij het vuur zat en wist hoe de hazen liepen. In ieder geval wist hij dat het beeld behoorde tot de middeleeuwse kunstschatten en afkomstig was van de graftombe van Philips de Stoute en dat de Pleurants bij de verkoop van de kloostergoederen uitgesloten waren geweest. Ook wist hij dat de gemeente Dijon de beelden had gered na het vernietigingsbevel van de

30 F. Fauber, Mystery of the missing mourners, in: Pittsburgh Post-Gazette, 3 januari 1958.

31 Fauber, noot 30.

32 Cths.fr/ Louis-Bénigne Baudot. 


\section{VAN DER VEN, F.A.J.}

koninklijke beeltenissen in 1793. Hij schreef immers zelf dat er in 1793 een paar waren gestolen. Had Baudot zich niet op zijn minst achter de oren moeten krabben toen hij het beeld kocht? Of heeft hij het beeld helemaal niet gekocht, maar is hij er op onoirbare wijze aan gekomen? Ik kan me zo voorstellen dat hij als vooraanstaand man in Dijon niet meteen de verdenking op zich laadde, rustig zijn gang kon gaan en met No 17 onder de arm naar huis kon lopen.

Het vermoeden is gerechtvaardigd dat, zoals de Staat in de procedure ook zou opmerken, Pleurant No 17 na 1793 op onregelmatige wijze uit het nationale domein was verdwenen. Op welke wijze en wie er nu precies met No 17 aan de haal was gegaan blijft gissen. Hoewel de familie Perret-Carnot het beeld sinds 1813 in bezit had, is het niet al die tijd verborgen gebleven. No 17 werd in 1914 ontdekt. In de verslagen van de 'Académie des Inscriptions et Belles-Lettres' lezen we dat M. Andrieu, die over de Pleurants had gepubliceerd, in dat jaar een nieuwe Pleurant had gevonden in de particuliere collectie van M. Perret-Carnot, à Cercy (Saône-et-Loire). ${ }^{33}$ Dit zal vermoedelijk de kleinzoon zijn geweest van monsie ur Perret-Carnot, die het beeld in 1813 had gekocht. De Staat heeft al die tijd niets van zich laten horen.

\section{Gang van de procedure. Un détournement de procédure et de pouvoir?}

Zoals hierboven al is gezegd, vroeg het veilinghuis in 2014 de Minister om een uitvoercertificaat. Volgens de Code $d u$ patrimoine mogen cultuurgoederen, die een historisch, artistiek of archeologisch belang vertegenwoordigen alleen dan worden uitgevoerd als de eigenaar van de Minister van Cultuur een certificaat heeft gekregen. Het certificaat bevestigt voor eens en voor altijd dat het goed dat mag worden uitgevoerd niet het karakter heeft van een nationale schat. ${ }^{34}$ Voor trésors nationaux geldt een exportverbod.

De Minister weigerde per brief van 3 december 2014 afgifte van het certificaat en vorderde in hetzelfde schrijven met de revindicatie teruggave van het beeld. Hij nam niet de moeite de zussen zelf een brief te schrijven.

De zussen lieten het er niet bii zitten en tekenden bij de bestuursrechter in Pariis bezwaar aan tegen de weigering. Voorts waren ze het natuurlijk niet eens met het standpunt van de Staat over de eigendom. Het Tribunal administratif, de Franse bestuursrechter, stelde hen

33 M. Andrieu, schrijver van 'Les pleurants aux tombeaux des ducs de Bourgogne', zei in de vergadering 1 mei 1914 dat hij nr 17 had gevonden bij M. Perret-Carnot, à Cercy (Saône-et-Loire). Zie: Comptes rendus des séances de l'Académie des Inscriptions et Belles-Lettres 1918, 62-3, 221.

34 L 111-2: L'exportation temporaire ou définitive hors du territoire douanier des biens culturels, autres que les trésors nationaux, qui présentent un intérêt historique, artistique ou archéologique et entrent dans l'une des catégories définies par décret en Conseil d'Etat est subordonnée à l'obtention d'un certificat délivré par l'autorité administrative. Ce certificat atteste à titre permanent que le bien n'a pas le caractère de trésor national (...). 


\section{EEN TREURENDE MONNIK EN EEN ADELAAR}

in het ongelijk ${ }^{35}$ waarop ze in appèl gingen bij Cour administrative d'appèl. ${ }^{36}$ Ook bij deze rechter vingen ze bot. Ten slotte zochten ze hun heil bij de hoogste bestuursrechter, de Conseil d'État, dat op 21 juni 2018 uitspraak deed. ${ }^{37}$ De Conseil d'État gaf de rechter in eerste aanleg en de rechter in appèl gelijk. De Minister had het uitvoercertificaat terecht geweigerd en de Staat, die zich op het standpunt stelde eigenaar te zijn, kreeg ook hier het gelijk aan zijn zij. De zussen moesten het beeld afstaan. De rechter bevestigde de eigendom van de Staat aan de hand van een tweetal wetten die tijdens de Franse revolutie waren uitgevaardigd. Verder ging deze zaak, zoals vele bestuursrechtgeschillen, over allerle i procedureel geharrewar.

Voordat we hieronder de eigendoms vraag, de vraag waar het ons om te doen is, behandelen, een enkele opmerking over de bevoegdheid van de rechter. De administratieve rechter was bevoegd omdat het immers ging om een beschikking van de Minister van Cultuur die afgifte van een uitvoercertificaat had geweigerd. De Minister had, zoals gezegd niet alleen de afgifte geweigerd, maar in hetzelfde schrijven tevens namens de Staat het beeld opgeëist. Dit nu is opmerkelijk. Het feit dat de Minister van mening was dat het beeld eigendom was van de Staat en behoorde tot de trésors nationaux, leverde weliswaar een argument op om de afgifte te weigeren, maar kon hij, de Minister, namens de Staat, zomaar in dezelfde afwijzende beschikking de revindicatie instellen? De zussen stelden dan ook dat de revindicatie bij de behandeling van een aanvraag voor een uitvoercertificaat, een aantasting van hun recht en un détournement de procédure et de pouvoir opleverde.

De hoogste bestuursrechter, de Conseil d'État, oordeelde, in navolging van de eerste twee instanties, dat er geen bepaling bestond die de Staat bij het onderzoek dat hij verrichtte naar aanleiding van een verzoek om een uitvoercertificaat, verbood om zich af te vragen of het goed mogelijk behoorde tot het publieke domein. ${ }^{38}$ De Minister van Cultuur had zich dan ook niet schuldig gemaakt aan détournement de procédure et de pouvoir. De volgende vraag is dan of de Staat over de eigendomsvraag vervolgens niet de gang naar de burgerlijke rechter had moeten maken en in een afzonderlijke procedure de revindicatie had moeten instellen.

Hierover oordeelde de Conseil d'État dat de Staat niet een dergelijke plicht had omdat er geen bepaling was die de Staat daartoe verplichtte. De aanmaning aan verzoekers om het litigieuze beeld terug te geven, was slechts het noodzakelijke gevolg van de reden om het uitvoercertificaat te weigeren. De bestuursrechter in appèl had geen blijk gegeven van een onjuiste rechtsopvatting en was niet buiten zijn bevoegdheid getreden door over het bestaan, de omvang en de grenzen van het publieke domein te oordelen, en kennis te nemen van het geschil zonder een prejudiciële vraag te stellen. ${ }^{39}$

35 TA Paris, 5 nov. 2015, $\mathrm{n}^{\circ}$ 1430948/5-1, AJDA 2016. 496. De uitspraak is te raadplegen via: www.paris .tribunal-adminis tratif.fr

36 CAA Paris, 13 januari 2017, $\mathrm{n}^{\circ}$ 15PA04256. De uitspraak is te raadplegen via: www.legifrance-gouv.fr

37 No 408822. De uitspraak is te raadplegen via: www.cons eil-etat.fr

$38 \quad$ Zie voor de vindplaats noot 37 .

39 Zie voor de vindplaats noot 37. 


\section{Argumenten van partijen over de eigendom}

Zowel de zussen als de Staat beriepen zich in het geschil op decreten uit de tijd van de Franse revolutie. Het standpunt van de Staat was duidelijk. Pleurant No 17 was een nationale schat en behoorde tot het nationale domein en kon daarom niet worden uitgevoerd. Vanaf 2 november 1789, de dag waarop bij wet van de Assemblée de kerkelijke goederen in eigendom aan de Staat waren overgegaan, had de Staat de eigendom verkregen van het klooster Champmol met de daarin aanwezige graftombes van de hertogen van Bourgondië, versierd met de wenende monniken, inclusief No 17. De Staat was altijd eigenaar gebleven omdat het beeld tot de kerkelijke goederen was blijven behoren en daarmee tevens tot het nationaal domein. Het beeld was op onregelmatige wijze uit het nationale domein verdwenen.

De Staat had naar eigen zeggen nooit de privé-eigendom van de familie Perret-Carnot erkend. Het beeld dat aan het 'openbaar nut' was toegewezen tijdens de verplaatsing van de graftombe van de hertogen van Bourgondië naar de kerk Sainte-Bénigne te Dijon, en vervolgens was toegevoegd aan de nationale openbare collecties, vormde een nationale schat in de zin van artikel L 111-1 van de Code du patrimoine en kon daarom, zoals gezegd, niet worden uitgevoerd. ${ }^{40}$

Tevens deed de Staat een beroep op de 'Code général de la propriété des personnes publiques' van 2006, en wel op artikel L 3111-1:

'Les biens des personnes publiques mentionnées à l'article L. 1, qui relèvent du domaine public, sont inaliénables et imprescriptibles'.

Artikel L. 1 luidt als volgt:

'Le présent code s'applique aux biens et aux droits, à caractère mobilier ou immobilier, appartenant à l'Etat, (..).'

Het voorgaande betekent letterlijk dat roerend en onroerend goed, dat deel uitmaakt van het

40 L 1-111: Les biens appartenant aux collections publiques et aux collections des musées de France, les biens classés en application des dispositions relatives aux monuments historiques et aux archives, ainsi que les autres biens qui présentent un intérêt majeur pour le patrimoine national au point de vue de l'histoire, de l'art ou de l'archéologie sont considérés comme trésors nationaux. L 111-2: L'exportation temporaire ou définitive hors du territoire douanier des biens culturels, autres que les trésors nationaux, qui présentent un intérêt historique, artistique ou archéologique et entrent dans l'une des catégories définies par décret en Conseil d'Etat est subordonnée à l'obtention d'un certificat délivré par l'autorité administrative. Ce certificat atteste à titre permanent que le bien n'a pas le caractère de trésor national (...). 


\section{EEN TREURENDE MONNIK EN EEN ADELAAR}

publiek domein, aan de Staat toebehoort. Het mag noch worden vervreemd en is ook niet voor verjaring vatbaar. $^{41}$

De zussen achtten de Code général de la propriété des personnes publiques echter niet van toepassing omdat het beeld na de Franse revolutie sans affectation publique was gebleven: de Staat had het beeld altijd als privé-eigendom beschouwd en had nooit iets tegen hun voorouders ondernomen. ${ }^{42}$ Dat het beeld niet tot het publieke domein behoorde beargumenteerden de zussen met een decreet van de Nationale Grondwetgevende Vergadering uit 1790. Dit decreet had het mogelijk gemaakt dat domeingoederen vanaf het inwerkingtreden van het decreet mochten worden vervreemd en voor verjaring vatbaar waren. Het moge duidelijk zijn dat met name de mogelijkheid van verkrijgende verjaring de zussen als muziek in de oren klonk. Zij beriepen zich op artikel 36 van bovengenoemd decreet. Deze bepaling luidt als volgt:

'La prescription aura lieu à l'avenir pour les domaines nationaux dont l'aliénation est permise par les décrets de l'ass emblée nationale, et tous les détenteurs (detempteurs) d'une portion quelconque des dits domaines, qui justifieront en avoir joui par eux-mêmes ou par leurs auteurs, à titres de propriétaires, publiquement et sans trouble, pendant quarante ans continuels à compter du jour de la publication du présent décret, seront à l'abri de toute recherche.' 43

Het artikel bepaalt dat verjaring kon plaatshebben van nationale eigendommen waarvan de vervreemding was toegestaan door de decreten van de Assemblée nationale en dat alle houders van enig deel van die eigendommen, die gerechtigd waren het genot te hebben voor zichzelf of door middel van anderen, veilig waren voor elk onderzoek als ze gedurende veertig jaren onafgebroken vanaf de dag van publicatie van dit decreet, als eigenaren, openlijk en ongestoord het genot ervan hadden gehad.

De zussen redeneerden als volgt. Mocht hun overgrootvader in 1813 bij de koop ${ }^{44}$ om de een of andere reden geen eigenaar zijn geworden, dan toch had hij of zijn zoon, in ieder

41 L 2112-1: Sans préjudice des dispositions applicables en matière de protection des biens culturels, font partie du domaine public mobilier de la personne publique propriétaire les biens présentant un intérêt public du point de vue de l'histoire, de l'art, de l'archéologie, de la science ou de la technique. De 'code général'geeft een definitie van de roerende domeingoederen, niet in het algemeen, maar juist gericht op roerende goederen met een culturele roeping. De definitie is ontleend aan artikel 14 'de la loi du 31 décembre 1913 relative aux monuments historiques'. Het richt zich op goederen van algemeen belang voor de geschiedenis, archeologie, wetenschap of de techniek. Guide pratique d'utilisation du code général de la propriété des personnes publique, 19. Te raadplegen op: www.collectiviteslocales.gouv.fr/files/files/Guide_pratique_CG3P.pdf.

$42 \quad$ Zie appèlrechter, noot 36.

43 Decreet van 28 november-1 december, in: Collection des Décrets d'Assemblée nationale constituante, ed. M. Arnoult, deel 15, Dijon 1792, 469. Zie ook: uitspraak Conseild'État, noot 37.

44 Naar Frans recht gaat de eigendom over op het moment van het totstandkomen van de koopovereenkomst. Artikel 711 Cc jo 1138 Cc. F. Terré, P. Simler, Droit civil, Les Biens, Parijs 2006, par. 442 v.; W.J. Zwalve, Hoofdstukken uit de Geschiedenis van het Europese Privaatrecht, Inleiding en Zakenrecht, Den Haag 2006, 281 v. 


\section{VAN DER VEN, F.A.J.}

geval door verjaring de eigendom van het beeld verkregen; de zussen waren vervolgens door erfopvolging eigenaar geworden. De Staat had het beeld volgens de zussen, zoals gezegd, altijd als privé-eigendom beschouwd; de Staat had nooit iets ondernomen waaruit het tegendeel bleek. De overgrootvader en zijn erfgenamen hadden geen enkele reden gehad om het beeld verborgen te houden. De familie onderhield regelmatig contact met wetenschappers die over het beeld publiceerden en zij had het beeld verschillende keren uitgeleend aan musea in Frankrijk en in het buitenland. Tijdens de bruikleenperiodes hadden de musea de familie als eigenaar erkend en ook als zodanig behandeld. In de musea stond op het bordje met tekst en uitleg dat het beeld uit een privécollectie afkomstig was.

Zoals we straks zullen zien, is over hun conclusie naar aanleiding van artikel 36 het nodige te zeggen. Maar we laten eerst de Staat en de rechter aan het woord.

De Staat weersprak het standpunt van de zussen en was de mening toegedaan dat er van verjaring geen sprake kon zijn geweest. De Staat beriep zich hiervoor eveneens op het decreet van 1790. De Staat was van mening dat artikel 36, dat verjaring mogelijk maakte, in samenhang gelezen moest worden met artikel 8 van het decreet. In artikel 8 wordt gezegd dat goederen uit het nationale domein alleen dan verkocht en vervreemd mochten worden als er toestemming was gegeven door middel van een formeel decreet van het wetgevend orgaan, dat daarna door de koning bekrachtigd was:

'Les domaines nationaux et les droits qui en dépendent sont et demeurent inaliénables, sans le consentement ou le concours de la nation; mais ils peuvent être vendus et aliénés (...) en vertu d'un décret formel du corps légis latif, sanctionné par le roi.' 45

Uit het voorgaande volgde, zo beweerde de Staat, dat de verjaring krachtens artikel 36 dan ook alleen mogelijk was van die goederen, die krachtens een formeel besluit van de wetgevende instantie, gesanctioneerd door de Koning, hadden mogen worden vervreemd. Nu er met betrekking tot het litigieuze beeld noch een dergelijk besluit met toestemming tot verkoop, noch een bekrachtiging door de koning daartoe voorhanden was, kon het dan ook niet door verjaring zijn verkregen.

\section{Uitspraak}

De Staat kreeg in juni 2018 van alle instanties gelijk. De Conseil d'État concludeerde dat het beeld sinds 1789, toen het als onderdeel van de kerkelijke goederen in handen van de Staat was gevallen, altijd tot het nationale domein was blijven behoren, waaraan het vervolgens op onregelmatige wijze was onttrokken. En voorts dat de rechter in appèl geen blijk had gegeven van een onjuiste rechtsopvatting. Nadat deze had vastgesteld dat er geen formeel wetgevingsbesluit was geweest dat vervreemding van het beeld toestond had hij terecht geoordeeld dat er ook geen beroep op verjaring kon plaatsvinden ten voordele van

45 Collection, noot 43, deel 15, Dijon 1792, 462. Zie ook: uitspraak Conseild'État, noot 37. 


\section{EEN TREURENDE MONNIK EN EEN ADELAAR}

de opeenvolgende houders, wat er van de goede trouw ook mocht zijn. ${ }^{46}$ Artikel 36 moest in samenhang met artikel 8 worden gelezen.

Dat de Staat nooit iets had ondernomen tegen het gegeven dat het feitelijke bezit in andere handen was kon de Staat niet beletten zijn eigendomsrecht, dat eeuwig was, op het beeld te doen gelden. De Minister kon daarom dan ook het verzoek om afgifte van een uitvoercertificaat weigeren en de zussen bevelen het beeld aan de Staat terug te geven. ${ }^{47}$

\section{Enige opmerkingen over de uitspraak; een andere uitleg van het decreet.}

In de eerste plaats een opmerking over de interpretatie van het decreet van 1790 en de conclusie van de rechter dat artikel 36 in samenhang met artikel 8 gelezen moest worden. Deze uitleg, dat de zussen alleen dan ex artikel 36 van het decreet een beroep op verjaring konden doen als er voor het beeld een formeel vervreemdingsbesluit was geweest dat bekrachtigd was door de koning, lijkt aannemelijk, maar wekt tegelijkertijd enige bevreemding. We herhalen de inhoud beider bepalingen.

Artikel 8 bepaalt dat vervreemding van een goed uit het nationaal domein mogelijk was, mits er toestemming was gegeven bij wet, bekrachtigd door de koning. De Staat was eigenaar van het domeingoed en kon dus vervreemden, maar er moest wel zijn voldaan aan een formaliteit, zodat er niet te 'lichtvaardig' zou worden vervreemd, vandaar de bekrachtiging door de koning. Artikel 36 zegt dat verjaring kon plaatshebben van nationale eigendommen waarvan de vervreemding was toegestaan door de decreten van de Assemblée nationale, en dat alle houders van enig deel van die eigendommen, die gerechtigd waren het genot te hebben voor zichzelf of door middel van anderen, veilig waren voor elk onderzoek als ze gedurende veertig jaren onafgebroken vanaf de dag van publicatie van dit decreet, als eigenaren, openlijk en ongestoord het genot ervan hadden gehad. Hoe moet artikel $36 \mathrm{nu}$ worden gelezen? Op het eerste gezicht lijkt, zoals de Staat en de rechter van mening waren, artikel 36 deze samenhang inderdaad te bepalen: "verjaring kan plaatshebben van nationale eigendommen waarvan de vervreemding is toegestaan door de decreten van de Assemblée nationale, (..).' 48

46 'Il résulte de ce qui précède que c'est sans entacher son arrêt d'inexacte qualification juridique des faits que la cour administrative d'appèl a jugé que le " pleurant ${ }^{\circ} 17$ » n'avait jamais cessé, depuis sa mise à disposition de la Nation en 1789, d'appartenir au domaine national puis au domaine public dont il a été irrégulièrement soustrait. Elle n'a pas davantage commis d'erreur de droit en en déduisant, après avoir relevé l'absence d'un décret formel du corps législatif autorisant expressément son aliénation, qu'il n'avait pu faire l'objet d'une prescription acquisitive au profit de ses détenteurs successifs, quelle que soit leur bonne foi.' Zie noot 37.

47 '(..) que ni cette possession de fait, ni l'inaction prolongée de l'Etat ne peuvent faire obstacle à ce que ce dernier fasse valoir son droit de propriété sur cet objet, qui est perpétuel s'agissant d'un bien relevant du domaine public affecté à l'utilité publique; que, par suite, la ministre de la culture et de la communication a pu, sans entacher sa décision d'illégalité, rejeter la demande des requérantes tendant à la délivrance d'un certificat d'exportation du " pleurant $n^{\circ} 17$ " et ordonner sa restitution à l'Etat au motif qu'il appartient au domaine public; (...).' Rechter in appèl, zie noot 36.

48 Cursivering door schrijver dezes. 


\section{VAN DER VEN, F.A.J.}

Maar artikel 36 bedoelt volgens mij niet meer te zeggen dan dat verjaring mogelijk is van domeingoederen die aan geformaliseerde toestemming onderhevig zijn. Het stelt die geformaliseerde toestemming niet als voorwaarde aan de verjaring zelf. In feite herhaalt artikel 36 slechts wat in artikel 8 reeds is gezegd, namelijk dat voor vervreemding geformaliseerde toestemming nodig is door middel van een wet en bekrachtiging. Als we artikel 36 lezen in samenhang met artikel 8, dan kan ik daaruit derhalve niet de geformaliseerde toestemming als dwingende voorwaarde voor de verjaring afleiden. De voorwaarden voor de verjaring worden in artikel 36 zelf genoemd, te weten: het openlijke en ongestoorde genot als eigenaar, onafgebroken gedurende veertig jaren, gerekend vanaf de dag van publicatie van het decreet.

Misschien was de verjaring ex artikel 36 juist mogelijk gemaakt voor goederen die in weerwil van een geformaliseerde toestemming uit het nationaal domein waren geraakt. In die zin is artikel 36 een aanvulling op artikel 8 en was verjaring mogelijk in het geval er dus iets aan de formaliteit had geschort; dat juist de bezitters van die goederen een beroep op verjaring konden doen. Men vergelijke de usucapio a domino in het Romeinse recht. Was een res mancipi zonder de voorgeschreven formaliteiten door traditio, door bezitsverschaffing, overgedragen, dan ging de eigendom niet over, maar kon de eigendom door usucapio (verjaring) a domino verkregen worden. ${ }^{49}$

Verjaring is een wijze van eigendomsverkrijging in die gevallen waarin er iets aan de overdracht heeft geschort en eigendom en bezit uit elkaar zijn geraakt en in twee verschillende handen zijn gekomen. ${ }^{50}$ De verjaring zorgt ervoor dat eigendom en bezit weer in één hand raken. Verjaring is een lapmiddel. Kortom, het lijkt mij logischer te denken dat de bedoeling van de opsteller van het decreet is geweest dat verjaring een oplossing bood voor die gevallen waarin juist geen toestemming op grond van een wet voorhanden was en de bezitter daarom geen eigenaar was geworden. Want waarom zou een beroep op verjaring nodig zijn als de vervreemding keurig met wettelijke toestemming en bekrachtiging had plaatsgehad?

Misschien was het decreet zelfs in de eerste plaats geschreven voor die gevallen waarin vervreemding reeds had plaatsgehad vóór het in werking treden van het decreet in 1790. Dit zou logisch zijn omdat dit decreet vervreemding voor het eerst toestond en wel in artikel 8 onder de voorwaarde dat er een wetsbesluit was dat door de koning bekrachtigd was; voordien gold het beginsel van onvervreemdbaarheid van domeingoederen. Het decreet moest een oplossing treffen voor die gevallen waarin goederen in strijd met dat beginsel reeds waren vervreemd. En die oplossing nu was de verjaring. Vandaar wellicht dat artikel 36 bepaalde dat de termijn begon te lopen bij het in werking treden van het decreet in 1790. Het lijkt ook onlogisch dat verjaring alleen dan mogelijk was als het een domeingoed betrof waarvoor de Staat formeel toestemming tot vervreemding had gegeven en de koning dit had

49 J.H.A. Lokin, Prota, Vermogensrechtelijke leerstukken aan de hand van Romeinsrechtelijke teksten, bewerkt door F. Brandsma, Groningen 2016, 159; M. Kaser, F.B.J. Wubbe, Romeins Privaatrecht, Zwolle 1971, $121 \mathrm{v}$.

50 F. Terré, P. Simler, Droit civil, Les Biens, Parijs 2006, par. 442 v. 


\section{EEN TREURENDE MONNIK EN EEN ADELAAR}

bekrachtigd. Immers, de Staat was eigenaar van het domeingoed. Zodra de Staat en de koning de toestemming hadden gegeven met alle toeters en bellen en het domeingoed in handen van de verkrijger was overgegaan, was het geen domeingoed meer. Een verjaringsregel voor domeingoederen ex artikel 36 was op dat goed niet meer van toepassing. Het goed dat geen domeingoed meer was, zou voortaan onderworpen zijn aan de 'normale' verjaringsregels van het ancien droit français. Kortom, volgens mij moet artikel 36 onafhankelijk van artikel 8 worden gelezen. Verjaring zou dan dus mogelijk zijn van goederen waarvoor niet de formele toestemming was verleend, zoals in ons geval. De vraag is echter of dat de zussen zou hebben geholpen.

Voorwaarde was volgens artikel 36 dat hun overgrootvader in de eerste plaats, als eigenaar het openlijke en ongestoorde bezit moest hebben gehad. ${ }^{51}$ Ongestoord wil zeggen dat een derde de zaak nooit van hem had opgeëist en hij het bezit had behouden. Over openbaar bezit bestaan verschillende meningen. De meeste schrijvers zeggen dat bezit niet-openbaar is als iemand heimelijk in het bezit van een zaak is getreden. Zij brengen het vereiste van openbaarheid in verband met het Romeinse possessio clandestina. ${ }^{52}$ Degene die heimelijk in het bezit is getreden, kan niet verjaren omdat hij niet te goeder trouw is. Waarschijnlijk daarom stelt artikel 36 naast het openbaar bezit niet apart de goede trouw als vereiste voor de verjaring. Openbaar bezit is voldoende. Perret-Carnot, de overgrootvader, die het bezit van het beeld in 1813 na de koop van zijn neef Baudot had verkregen, zou dus door verkrijgende verjaring eigenaar kunnen zijn geworden, mits hij openlijk en ongestoord het beeld in bezit had. Ongestoord was zijn bezit in ieder geval. Het bezit zou zelfs gedurende twee eeuwen ongestoord blijven. De Staat had nooit iets ondernomen.

Of Perret-Carnot het beeld ook openlijk in bezit had is niet duidelijk. De vraag die daarvoor moet worden beantwoord is of hij mogelijk heimelijk in het bezit van de zaak was getreden, met andere woorden of hij te goeder trouw was toen hij het beeld van zijn neef Baudot in 1813 kocht. Er kan op zijn minst aan de goede trouw van Perret-Carnot worden getwijfeld. Hij was verzamelaar, bekend in kunstkringen en derhalve op de hoogte van de geschieden is van Pleurant No 17. Daarbii is No 17 pas in 1914 ontdekt in de particuliere collectie van M. Perret-Carnot ${ }^{53}$, de kleinzoon van de Perret-Carnot, die het beeld in 1813 had gekocht. Dat wil zeggen dat het beeld eerst honderd jaar later is 'teruggevonden' en dus misschien bewust tot die tijd verborgen is gehouden. We weten het niet. Het is natuurlijk wel zo dat er in die tijd niet veel oog was voor het belang van dit soort objecten en het de gewoonste zaak van de wereld was ermee te handelen.

In 1958 kwam M. Perret-Carnot er zelf openlijk voor uit dat hij eigenaar was

51 Vgl. artikel 2261 Code civil: Pour pouvoir prescrire, il faut une possession continue et non interrompue, paisible, publique, non équivoque, et à titre de propriétaire. De toevoeging 'als eigenaar' is overbodig. Iemand die de zaak niet als eigenaar, maar bijvoorbeeld als bruiklener heeft, verjaart niet omdat hij geen bezitter is, maar houder. Terré-Simler, noot 50, par. 163 v. en 447. J.E. Jansen, Bezit te kwader trouw, verkrijgende en bevrijdende verjaring. Een leerstellige rechtsvergelijkende studie op historische grondslag, Den Haag 2011, 237.

52 Terré-Simler, noot 51, par. 166; Jansen, noot 51, 238.

53 Andrieu, noot 33, 221. 


\section{VAN DER VEN, F.A.J.}

van No 17. We lezen in dat jaar in the Pittsburgh Post-Gazette dat er gedoe was over 'het beeldje van eigenaar Perret-Carnot in Beaune'. Er was ruzie ontstaan vanwege een testament. Perret zou hierover volgens de krant hebben gezegd dat in ieder geval vast stond dat No 17 het land nooit zou verlaten. ${ }^{54}$ We brengen hier ook nog even het argument van de zussen in herinnering dat de familie regelmatig contact onderhield met wetenschappers die over het beeld publiceerden en dat het beeld verschillende keren was uitgeleend aan musea in Frankrijk en in het buitenland. Dit pleit tegen heimelijkheid.

Er is nog niets gezegd over het derde vereiste dat artikel 36 aan de verjaring stelt, te weten de termijn. Degene die zich op verjaring beriep, moest het bezit hebben gehad, (..) pendant quarante ans continuels à compter du jour de la publication du présent décret. (..). Dat wil zeggen dat hij veertig jaar lang onafgebroken bezitter moest zijn geweest, gerekend vanaf de dag dat het decreet was gepubliceerd.

Als we het decreet letterlijk uitleggen, dan betekent het voorgaande dat de zussen moesten kunnen aantonen dat hun overgrootvader vanaf 28 november 1790 veertig jaar lang bezitter was geweest. Het is duidelijk dat hij nooit veertig jaar gerekend vanaf 1790 bezitter kon zijn geweest omdat hij pas in 1813 het bezit in handen had gekregen. Het lijkt dus enigszins merkwaardig dat de zussen een beroep deden op artikel 36. De rechter zegt hier niets over omdat hij het beroep op verjaring bij voorbaat al had afgewezen omdat de Staat nooit bij wet in de vervreemding van het beeld had toegestemd en er dus ook geen bekrachtiging van de koning voorhanden was.

De zussen zelf legden ook niet uit hoe zij de termijn berekenden. Lieten zij, wat het meest voor de hand ligt, de termijn beginnen in 1813 op het moment dat hun overgrootvader het beeld kocht en het bezit verkreeg? In dat geval zou de overgrootvader, of in ieder geval zijn zoon, in 1853 eigenaar zijn geworden door verjaring. Of telden de zussen de termijn van de voorgangers van hun grootvader erbij op, te weten, Baudot en diens voorgangers. Maar dat snijdt geen hout, want er bestonden geen voorgangers die terug te leiden waren naar 1790 . Sterker nog in 1790 was de Staat, als eigenaar van de kerkelijke goederen nog eigenaar van het klooster inclusief de graftombes. Hoewel het uit de letterlijke tekst niet kan worden opgemaakt is het het meest logisch te zeggen dat eerst met het inwerking treden van het decreet in 1790 in zijn algemeenheid een beroep op verjaring mogelijk was voor die gevallen waarin vervreemding vóór 1790 in strijd met het vervreemdingsverbod had plaats gevonden én voor díe gevallen ná 1790 waarin de formaliteit van toestemming en bekrachtiging ontbraken. En dat de bezitter die een beroep op verjaring wilde doen, het bezit veertig jaar lang moest hebben gehad vanaf de dag dat hij het bezit verkreeg.

Leggen we het decreet uit op deze wijze, zoals het mijns inziens door de wetgever is bedoeld, dan lijkt de conclusie te moeten zijn dat de zussen voor de verkrijgende verjaring met succes beroep op het decreet hadden kunnen doen. Aan de vereiste termijn van veertig jaar, gerekend vanaf het moment van de bezitsverkrijging in 1813, was in ieder geval

54 Pittsburgh Post-Gazette, noot 30. 


\section{EEN TREURENDE MONNIK EN EEN ADELAAR}

voldaan. Toch zou daar met de invoering van de Code civil in 1804 waarschijnlijk een stokje voor zijn gestoken. We komen hier straks op terug nadat we het beroep van de zussen op het Europees Verdrag tot Bescherming van de Rechten van de Mens (EVRM) en de uitspraak van de rechter hierover hebben besproken.

\section{Europees Verdrag tot Bescherming van de Rechten van de Mens (EVRM)}

Het Franse revolutierecht bood de zussen geen bevredigende oplossing. De zussen hadden nog een ijzer in het vuur. Zij deden in deze zaak namelijk ook een beroep op artikel 1 van het eerste protocol van het ERVM. Artikel 1, dat eigendom beschermt, luidt als volgt:

\footnotetext{
1-Iedere natuurlijke of rechtspersoon heeft recht op het ongestoord genot van zijn eigendom. Aan niemand zal zijn eigendom worden ontnomen behalve in het algemeen belang en onder de voorwaarden voorzien in de wet en in de algemene beginselen van internationaal recht.

2-De voorgaande bepalingen tasten echter op geen enkele wijze het recht aan, dat een Staat heeft om die wetten toe te passen, die hij noodzakelijk oordeelt om het gebruik van eigendom te reguleren in overeenstemming met het algemeen belang of om de betaling van belastingen of andere heffingen of boeten te verzekeren.
}

Wil een beroep op artikel 1 kans van slagen hebben, dan moet het in de eerste plaats gaan om een goed dat onder de bescherming van artikel 1 valt. Is dat het geval, dan leidt het beroep op artikel 1 in de meeste gevallen tot een afweging tussen het privébelang van de burger en het publieke of algemene belang. De ervaring leert dat de burger vaak aan het kortste eind trekt. Meestal prevaleert het algemeen belang, zo ook in ons geval.

Volgens de Conseil d'État had de appèlrechter, 'rekening houdend met de omstandigheden, in het bijzonder met de tijdsduur dat de familie het litigieuze beeld in bezit had, terwijl de Staat geen enkel initiatief toonde het terug te krijgen, voldoende erkend dat de familie aanspraak kon maken op het vreedzaam genot van hun bezit'. 'Doch de erkenning dat het beeld tot het publiek domein behoorde rechtvaardigde dat het aan de eigenaar, dat wil zeggen aan de Staat, zou worden teruggegeven, zonder voorbij te gaan aan het vereiste van een billijk evenwicht tussen de particuliere belangen van de houders en het grote publieke belang dat verbonden was aan het behoud van het beeld in het publiek domein en de bescherming van dit kunstwerk.' ${ }^{55}$

55 'La cour administrative d'appèl, qui a retenu une exacte qualification juridique des faits en reconnaissant l'existence, dans les circonstances de l'espèce, compte tenu notamment de la durée pendant laquelle la statuette litigieuse avait été détenue par les requérantes sans initiative de l'Etat pour la récupérer, d'un intérêt patrimonial à en jouir, suffisamment reconnu et important pour constituer un bien au sens des stipulations précitées, n'a pas commis d'erreur de droit en jugeant que la reconnaissance de son appartenance au domaine public justifiait qu'il soit rendu à son propriétaire, l'Etat, sans que soit méconnue l'exigence de respect d'un juste équilibre entre les intérêts privés de ses détenteurs et l'intérêt public majeur qui s'attache à la protection de cette æuvre d'art.' Zie noot 37. 
Deze uitspraak lijkt een doekje voor het bloeden. De rechter had de aanspraak op het vreedzame genot van het beeld voldoende erkend. Maar wat hadden de zussen aan de erkenning van deze aanspraak terwijl de rechter tegelijkertijd concludeerde dat de Staat eigenaar was en dat de zussen het beeld moesten afgeven? Voorts was de appèlrechter volgens de Conseil d'État niet 'voorbij gegaan aan het vereiste van een billijk evenwicht tussen het particuliere en het algemene belang'. 'Evenwicht' lijkt hier een ongelukkige term omdat evenwicht suggereert dat de twee belangen even groot, dat wil zeggen, in evenwicht zijn. Evenwicht is immers de toestand waarin het gewicht aan beide zijden van bijvoorbeeld een weegschaal of een wipwap gelijk is. In ons geval echter sloeg de ene kant van de wipwap met daarop de Staat met een klap op de grond, met als gevolg dat de zussen er aan de andere kant met een boog vanaf vlogen.

Er was dus geen sprake van een billijk evenwicht tussen de beide belangen, maar van een afweging van beide belangen waarbij de rechter het billijk vond dat het publieke belang zwaarder woog. Het beeld zou volgens de rechter, als de Staat het bezit ervan kreeg, niet aan de openbaarheid worden onttrokken en het zou ook beter kunnen worden beschermd. Alsof een particulier dat laatste niet kan; de familie Perret-Carnot was daar juist een mooi voorbeeld van. $\mathrm{Zij}$ had het beeld gedurende twee eeuwen goed bewaard. Evenmin had zij het aan de openbaarheid onttrokken, gezien de bruikleen aan verschillende musea. De rechter zegt vreemd genoeg niets over het feit dat de Staat sinds 1914 op de hoogte was van het bestaan van Pleurant No 17 en vervolgens honderd jaar lang niets heeft ondernomen. Pas toen de zussen om een certificaat vroegen en de Staat het beeld dus op een presenteerblaadje kreeg aangereikt werd actie ondernomen.

Weliswaar bestond de kans dat het beeld na de beoogde veiling zou verdwijnen naar een slaapkamer in het buitenland, maar men kan zich afvragen waarom het privébelang om die reden het onderspit zou moeten delven.

\section{Waren er mogelijke andere verweren voor de zussen te bedenken geweest?}

\section{$1^{\mathrm{e}}$ mogelijke verweer: verkrijgende verjaring op grond van de Code civil.}

De appèlrechter had nog opgemerkt dat het beeld niet in aanmerking kwam voor toepassing van de 'gewone' verjaringsregels uit de Code civil. ${ }^{56}$ Hij legde verder niets uit.

Men zou zich kunnen afvragen waarom het feit dat de Staat twee eeuwen had nagelaten tegen de bezitter op te treden geen gevolg had voor zijn eigendomsrecht. Onafgebroken verjaringsbezit van goederen kan op grond van artikel $2261 \mathrm{Cc}$ na dertig jaar uitgroeien tot eigendom $^{57}$, ook als de bezitter niet te goeder trouw is. Niet omdat de revindicatie is verjaard, maar omdat de eigenaar 'steeds heeft nagelaten tegen de verjaringsbezitter op te

56 '(..) que, saufautorisation législative préalable formelle, prise sur le fondement du décret de l'Assemblée constituante des 28 novembre et ler décembre 1790, ces biens inaliénables et imprescriptibles ne peuvent être l'objet de la prescription acquisitive prévue par l'article 36 de ce texte, ni des règles de prescription ultérieurement instituées parle code civil;(..). 'Zie appèlrechter, noot 36.

$57 \quad$ Zie voor de tekst noot 51. 


\section{EEN TREURENDE MONNIK EN EEN ADELAAR}

treden, terwijl de verjaringsbezitter zich steeds om de zaak heeft bekommerd'. ${ }^{58}$ De Fransen redeneren als volgt. De eigenaar verliest de revindicatie pas wanneer iemand anders de eigendom van zijn zaak verkrijgt, dus wanneer het eigendomsrecht voor hem verloren gaat. De rechtsvordering van de eigenaar gaat dus alleen indirect verloren, dat wil zeggen wanneer de bezitter door verkrijgende verjaring eigenaar wordt. ${ }^{59}$ Toegepast op de casus betekent dit dat de overgrootvader dertig jaar na de koop in 1813, dus in 1843 mogelijk door verkrijgende verjaring eigenaar was geworden, als gevolg waarvan de Staat de revindicatie had verloren. Leefde hij inmiddels niet meer, dan had zijn zoon door verjaring de eigendom verkregen. Uit hoofde van de accessio possessionis-regel zetten de opvolgers onder algemene titel, de familieleden in de rechte lijn, de lopende verjaring steeds voort. ${ }^{60} \mathrm{De}$ zussen op hun beurt zouden door erfopvolging de eigendom hebben verkregen.

Zou dit verweer kans van slagen hebben gehad?

Tegenwoordig bepaalt artikel L 3111-1 van de Code général de la propriété des personnes publiques van 2006, zoals gezegd, dat goederen die tot het publieke domein behoren niet mogen worden vervreemd en ook niet voor verjaring vatbaar zijn. ${ }^{61}$ De domeingoederen, waartoe ook veel cultuurgoederen behoren, zijn res extra commercium $^{62}$, dat wil zeggen zaken die door de bepalingen van het stellige recht aan het rechtsverkeer zijn onttrokken. ${ }^{63}$ Zij zijn dus te beschouwen als res inhabiles, zaken die niet voor verjaring vatbaar zijn. ${ }^{64} \mathrm{De}$ Staat behoudt te allen tijde de eigendom en kan altijd de revindicatie instellen. ${ }^{65}$ Het

58 Jansen, noot 51, 198.

59 De revindicatie gaat dus niet door bevrijdende verjaring teniet. Cass. Civ. 3e , 2 juni 1993 affaire de la succession d'Ambroise Vollard, Bull. Civ. III no 197; D., 1993, somm. 306: 'L'action en revendication $n$ 'est pas susceptible de prescription extinctive.' Terré-Simler, noot 50, 514. Vgl. voor onroerende zaken het arrest van het Cour de Cassation Le Cohu C. Morvan Req. 12 juli 1905, D. 1907.1.141, 144. Hierover: W.J. Zwalve, Le Cohu C. Morvan Req. 12 juillet 1905 (Dalloz. 1907.1.141), in: NTBR 2006-7, 23, 276282. Jansen, noot 51, $191 \mathrm{v}, 198,216$. Naar Nederlands recht verjaart de revindicatie na twintig jaar en degene die een goed bezit op het tijdstip waarop de verjaring van de rechtsvordering strekkende tot beëindiging van het bezit wordt voltooid, verkrijgt dat goed, ook al was zijn bezit niet te goeder trouw. Artikel 3: 306 BW jo artikel 3:105 lid 1 BW. Jansen, noot 51, $191 \mathrm{v}, 198,215$.

60 Artikel $2265 \mathrm{Cc}$, waarin we de accessio possessionis-regel uit het Romeinse recht terugvinden. Krachtens deze regel kan de bezitter de bezitstijd van zijn voorgangerbij die van hemzelf optellen. 'De opvolger onder algemene titel wordt vereenzelvigd met zijn voorganger en zet een lopende verjaring steeds voort. De opvolger onder bijzondere titel zet een lopende verjaring alleen voort als hij zelf voldoet aan de aan voor de verkrijging door verjaring gestelde eisen.' Jansen, noot 51, 195. Lokin-Brands ma, noot 49, 167; Terré-Simler, noot 50, par. 166.

61 'Les biens des personnes publiques mentionnées (..), qui relèvent du domaine public, sont inaliénables et imprescriptibles'. El-Bitar, noot 13, 48. Vgl. Chatelain-Chatelain, noot 12, 30; Poli, noot 12, 287. Terré-Simler, noot 50, par. Par 538 v.

62 Eenzelfde opvatting huldigen Italië, België, Luxemburg, Spanje en Griekenland. El-Bitar, noot 13, 35 en 49; A. Weidner, Kulturgüter als res extra commercium im internationalen Sachenrecht, Berlijn 2001, Reprint 2013, 36. Garducci, noot 12, 43 v.

63 Lokin-Brandsma, noot 49, 99; Kaser, Wubbe, noot 49, 93 v.

64 Lokin-Brandsma, noot 49, 160; Kaser, Wubbe, noot 49, 123.

65 El-Bitar, noot 13, 35. Le principe de l'imprescriptibilité s'applique aux actions en revendication des biens irrégulièrement aliénés, aux actions en réparation des dommages causés au domaine (contravention de voirie) et aux oeuvres d'art faisant partie du domaine public mobilier. Guide pratique, noot 41, 120. 


\section{VAN DER VEN, F.A.J.}

voorgaande is tegenwoordig de regel. De vraag is echter of deze wet uit 2006 mag worden tegengeworpen in de casus van No 17, in welk geval de verjaring mogelijk al in de negentiende eeuw had plaatsgevonden. Moet er dus niet veeleer worden gekeken naar wat toen rechtens was?

Dat domeingoederen niet voor vervreemding en verjaring vatbaar zijn is niet nieuw. Dat domeingoederen res extra commercium zijn, is terug te voeren op het Romeinse recht. Een enkele opmerking hierover. Voor het Romeinse recht was de regel gecodificeerd in C. 8, $12,6 .{ }^{66}$ Res publicae, zaken waarvan de Staat eigenaar was en die het openbaar nut dienden, waren zaken buiten de handel. ${ }^{67}$ Kunstwerken die tot de res publicae behoorden vielen dientengevolge eveneens onder de res extra commercium. Men denke aan een kunstwerk dat de overheid had gekocht of had laten maken ter versiering van openbare plaatsen als wegen, pleinen, theaters en gebouwen. ${ }^{68}$ Deze kunstwerken dienden een openbaar doel. Tot de res publicae behoorden ook de beelden die de overheid liet maken ter ere van bepaalde personen, en die op een openbare plaats werden neergezet. ${ }^{69}$

Kunstwerken die een religieus doel dienden behoorden tot de res divini iuris, zaken van goddelijk recht, en werden daarom eveneens onder de res extra commercium gerekend. ${ }^{70}$ De res divini iuris werden onderscheiden in res sacrae en res religiosae. ${ }^{71}$ Tot de res sacrae behoorden afbeeldingen van goden en zaken die bij de eredienst werden gebruikt, evenals de gewijde standbeelden van keizers. De plaats waar iemand begraven lag was, mits gewijd, een res religiosus. Niet de gehele voor de begraving bestemde plaats kreeg een gewijd karakter, maar voor zover het lichaam in de aarde neergelaten was. ${ }^{72}$ Een cenotaaf, een grafmonument, was geen res reliogiosus, en kon derhalve worden verkocht. ${ }^{73}$ Voor het overige waren kunstwerken res privatae, die ressorteerden onder het regime van het Romeinse privaatrecht. Toch ontstond in Rome de opvatting dat kunst in privébezit niet

66 C. 8, 12, 6: Praescriptio temporis juri publico non debet obsistere. A. B. des Glajeux, De l'aliénation et de la prescription des biens de l'État, des communes et des établissements publics dans le droit ancien et moderne, Parijs 1859, 106 v. 122 v.

67 Gaius, II, 11: Quae publicae sunt nullius videntur in bonis esse: (..). D. 1, 8, 1.

68 R. Saleilles, Le domaine publique à Rome et son application en matière artistique, in: Nouvelle revue historique de droit français et étranger, Parijs 1889, 457 v. 495. Weidner, noot 62, 20.

69 Saleilles, noot 68, $492 \mathrm{v}$. Weidner, noot 62, $15 \mathrm{v}$.

70 Weidner, noot 62, 15 v. Gaius, II, 9: Quod autem divini iuris est, id nullius in bonis est. (..). Vgl. D. 1, 8,1 .

71 Gaius II, 3: Divini iuris sunt veluti res sacrae et religiosae. Vgl. D. 1, 8, 1.

72 D. 11, 7, 2, 5 Ulpianus libro vicensimo quinto ad edictum: Sepulchrumest, ubi corpus ossave hominis condita sunt. Celsus autem ait: non totus qui sepulturae destinatus est, locus religiosus fit, sed quatenus corpus humatum est. I.t.t. Weidner die zegt dat kunstwerken die met een grafmonument verbonden waren, zoals beelden, res religiosae heetten omdat de begraafplaats met al zijn toebehoren een locus religiosus was. Weidner, noot $62,19$.

73 D. 11, 7, 6, 1 Ulpianus idem: (..) Si cenotaphiumfit, posse hoc venire dicendumest: nec enim esse hoc religiosum divi fratres rescripserunt. Wordt er een cenotaaf gebouwd, dan moet men concluderen dat die verkocht kan worden: de vergoddelijkte Broeders hebben namelijk bij rescript bepaald dat het hier niet om een gewijde plaats gaat. De vertaling van de Romeinsrechtelijke teksten is overgenomen uit: Corpus Iuris civilis, Tekst en Vertaling, o.r.v. J.E. Spruit e.a., II-VI, Den Haag 1994- 2001. 


\section{EEN TREURENDE MONNIK EN EEN ADELAAR}

alleen het belang van de eigenaar diende, maar ook dat van de gemeenschap. ${ }^{74}$ Sommige eigenaren maakten hun kunstbezit openbaar toegankelijk, door bijvoorbeeld standbeelden in de openbare ruimte te plaatsen. ${ }^{75}$ Als de beelden ter opluistering van de stad waren opgesteld, dan werden ze publiek eigendom. Ze konden echter ook eigendom worden van degenen te wiens ere ze waren opgesteld. ${ }^{76}$ Door het plaatsen in de openbare ruimte werden ze dus niet per se tot res publicae.

Voor Franse domeingoederen is de onvervreemdbaarheid en onverjaarbaarheid vastgelegd bij het Edict van Moulins van 1566 en het Edict van Colbert van 1667.77 De onverjaarbaarheid van domeingoederen was het gevolg van hun onvervreemdbaarheid. ${ }^{78}$ Bij

74 Weidner, noot $62,15 \mathrm{v}$.

75 D. 43, 9, 2 Paulus libro quinto sententiarum: Concedi solet, ut imagines et statutae, quae ornamenta rei publicae sunt futurae, in publicum ponantur. Vergunning pleegt verleend te worden tot het in het openbaar plaatsen van borstbeelden of standbeelden die het gemene best tot sieraad strekken.

76 D. 42, 5, 29 Paulus libro quinto ad legem Iuliam et Papiam: Fufidius refert statuas in publico positas bonis distractis eius, cuius in honorem positae sunt, non esse emptoris bonorum eius, sed aut publicas, si ornandi municipii causa positae sint, aut eius, cuius in honorem positae sint: et nullo modo eas detrahi posse. Fufidius deelt mee dat standbeelden die op een openbare plaats zijn opgesteld, wanneer het vermogen van degene te wiens ere deze zijn opgesteld verkocht wordt, niet aan de koper van dit vermogen toekomen, doch óf publiek [eigendom] zijn, als zij ter opluistering van de stad zijn opgesteld, óf eigendom blijven van degene te wiens ere zij zijn opgericht en dat zij in geen geval weggehaald kunnen worden. D. 41, 1, 41 Ulpianus libro nono ad edictum: Statuas in civitate positas civium non esse, idque Trebatius et Pegasus: dare tamen operam praetorem oportere, ut, quod ea mente in publico positum est, ne liceret privato auferre nec ei qui posuerit. tuendi ergo cives erunt et adversus petentem exceptione et actione adversus possidentem iuvandi. Vert.: Standbeelden die in de stad staan opgesteld behoren niet aan de burgers; dit [zeggen] Trebatius en Pegasus. Toch behoort de praetor er zich voor in te spannen dat wanneer iets op een openbare plaats opgesteld is met de bedoeling dat het een privaatpersoon niet toegestaan is dit weg te halen, dit laatste ook niet wordt toegestaan aan degene die het opgesteld heeft. Derhalve dienen de burgers zowel beschermd te worden met een exceptie tegen degene die daartoe een actie instelt alsook met een actie geholpen te worden tegen degene die er het bezit van heeft. Zie over deze tekst: Digest XLI. 1 De adquirendo rerum dominio, translated with notes by C.H. Monro, Cambridge 1933, 55, noot 41. Vgl. R.J. Pothier, Pandectae justinianeae, in novum ordinem digestae, cum legibus Codicis et Novellis, deel 1, Parijs 1818, Tit. VIII, 2, 11 (p. 45). Monro zegt dat de tekst op het eerste gezicht lijkt te zeggen dat de standbeelden eigendom zijn van de stad. Monro is van mening dat Ulipanus met civium hier niet de burgers bedoelt, maar de stad. (Vgl. Pothier: 'Id est, civitatisnon esse') Dit betekent dat als er een standbeeld in een stad wordt opgesteld, het beeld geen eigendom wordt van de stad, maar dat het in eigendom blijft van de degene die het beeld heeft neergezet. Niettemin, als een privé-persoon het terugeist, dan worden de burgers beschermd met een exceptie. Dit betekent dat de eis er eigenaar is.

77 A. B. des Glajeux, noot 66, 106 v. 122 v. Colbert, 'die zijn talent aan de wetgeving en zijn naam aan zijn jasje zou geven' regelde de financiën onder Lodewijk XIV en heeft het recht gedeeltelijk gecodificeerd. Lokin, Zwalve, Jansen, noot 21, 218.

78 De reden dat domeingoederen onverjaarbaar waren, was bovendien dat deze goederen dienden tot het algemeen nut van de maatschappij. Deze bestemming leverde voor iedereen een publiek recht op tegen welk recht zich men niet op verjaring kon beroepen; een individu mocht zijn belang niet boven dat van de maatschappij als geheel plaatsen. J. B. V. Proudhon, Traité du domaine public, ou de la distinction des biens, I, Dijon 1833-1834, 284. Omdat domeingoederen niet voorvervreemding vatbaar waren, kon men niet zonder kwade trouw op grond van een geldige titel het bezit hebben, en kon het bezit niet anders dan worden toegerekend aan de nalatigheid van overheidsfunctionarissen. Het gevolg van deze nalatigheid nu, zou niet mogen zijn dat de Staat eigendommen door verjaring zou verliezen die nodig 


\section{VAN DER VEN, F.A.J.}

het ons wel bekende artikel 36 van het decreet van decreet van 2 november 1790 is het beginsel van onvervreemdbaarheid verlaten waardoor er geen reden meer was om vast te houden aan de onverjaarbaarheid. ${ }^{79}$ Verjaarbaarheid was voortaan het principe: alienabile, ergo prescriptibile. In het decreet van 1790 werd nog geen onderscheid gemaakt tussen wat later 'domaine public' en 'domaine privé' zou gaan heten.

In de Code civil van Napoleon is dit onderscheid voor het eerst ingevoerd en uitgedrukt in de artikelen 2226 en 2227 . Artikel $2226 \mathrm{Cc}$ bepaalt het volgende:

Les choses qui font partie du domaine public étant, par leur destination, placées hors du commerce, sont par là même imprescriptibles. ${ }^{80}$

Goederen die tot het publiek domein behoorden waren res extra commercium en dus niet vatbaar voor verjaring in tegenstelling tot de goederen die behoorden tot het privédomein van de Staat. ${ }^{81}$ Artikel $2227 \mathrm{Cc}$ bepaalt het volgende:

L'État, les établissements publics et les communes sont soumis aux mêmes prescriptions que les particuliers, et peuvent également les opposer.

De Staat was voor wat zijn privé-eigendom aangaat aan dezelfde regels onderworpen als de burger. ${ }^{82}$ De verjaringstermijn was voor de in artikel 2227 bedoelde goederen dertig jaar. Voor sommige domeingoederen was het onderscheid tussen 'publiek' en 'privé' moeilijk te onderkennen. Ging het om wegen, rivieren en stranden, dan was het duidelijk. Zij behoorden ex artikel $538 \mathrm{Cc}$ tot het publiek domein; zij waren eigendom van de Staat en dienden een publiek doel. ${ }^{83}$ Deze twee criteria, het goed moet eigendom zijn van een overheidslicha a m, zoals de Staat, een departement of een gemeente en het goed moet een bepaald openbaar doel dienen (affectation), zijn tegenwoordig nog steeds bepalend. ${ }^{84}$ Bij sommige gebouwen of roerende goederen was het soms niet geheel duidelijk of zij een publiek doel dienden of niet. ${ }^{85}$ In de jurisprudentie en de literatuur is het onderscheid langzamerhand nader ingevuld. Baudry noemde het 1895 'une diffilculté très délicate' of roerend goed en dan in het

waren voor de verdediging en andere staatskosten. Aldus Bigot-Préameneu, een van de vier commissieleden die de Code civil hebben samengesteld, in: G. Baudry-Lacantinerie/A. Tissier, Traité théorique et pratique de droit civil, 9, De la prescription, Parijs 1895, 111.

79 Des Glajeux, noot 66,235 . Guide pratique, noot 41, 119.

80 Proudhon, noot 78, 272 v.

81 T. Huc, Commentaire théorique et pratique du Code civil, 14, Parijs 1902, 421.

82 Zie hierover R.T. Troplong, De la prescription, ou Commentaire du titre XX du livre III du Code Napoléon, deel 1, Parijs 1857, 301 v.; Des Glajeux, noot 66, 235 v.; Baudry-Lacantinerie/Tissier, noot $78,109 \mathrm{v}$.

83 Les chemins, routes et rues à la charge de l'Etat, les fleuves et rivières navigables ou flottables, les rivages, lais et relais de la mer, les ports, les havres, les rades, et généralement toutes les portions du territoire français qui ne sont pas susceptibles d'une propriété privée, sont considérés comme des dépendances du domaine public.

84 El-Bitar, noot 13, 48.

85 Baudry-Lacantinerie/Tissier, noot 78, 111. 


\section{EEN TREURENDE MONNIK EN EEN ADELAAR}

bijzonder of objecten die een religieus doel dienden, of tot een museum of archief behoorden onder het publiek domein begrepen konden worden en dus onvervreemdbaar en onverjaarbaar waren. ${ }^{86}$ De jurisprudentie was geneigd artikel $538 \mathrm{Cc}$ ruim uit te leggen en langzamerhand ontstond de opvatting dat ook roerend goed publiek domein kon zijn. ${ }^{87}$ Als deze goederen een publiek doel dienden, zoals objecten van musea en archieven, dan werden zij op grond van deze bestemming binnen het publieke domein getrokken. Sommige rechters vonden het al voldoende dat een object in een archief, museum of bibliotheek was geplaatst. ${ }^{88}$ Andere rechters eisten tevoren een formele beslissing oftewel een aanwijzing of classering van het kunstwerk tot publiek domeingoed. In 1887 werd de classering geregeld bij wet. Later is deze wet in 1913 vervangen door een wet die wel de 'moeder' van de Franse cultuurgoedbescherming wordt genoemd. ${ }^{89}$ De overheid kon goederen classeren die een nationaal belang vertegenwoordigden op het gebied van de historie of de kunst, als gevolg waarvan deze res extra commercium werden en dus onvervreemdbaar en onverjaarbaar waren. ${ }^{90}$ Deze wetten zijn de voorlopers van huidige Code du patrimoine.

Wanneer we de hierboven gestelde vraag beantwoorden, naar wat rechtens was in de negentiende eeuw, dan hangt het er dus vanaf of Pleurant No 17 tot het publiek domein of tot het privédomein van de Staat behoorde. Was dat laatste het geval, dan was een beroep op verkrijgende verjaring ex artikel $2261 \mathrm{Cc}$ mogelijk. Ik denk echter dat men zou kunnen zeggen dat het beeld tot het publiek domein behoorde. De andere beelden waren in 1799 immers tentoongesteld in het museum in Dijon. Was No 17 niet op onregelmatige wijze uit het domein verdwenen, dan zou het eveneens dit publieke doel hebben gediend. Artikel $2226 \mathrm{Cc}$ zou dus een stokje hebben gestoken voor het beroep op verjaring ex artikel 2261 Cc. ${ }^{91}$

86 Baudry-Lacantinerie/Tissier, noot 78, $89 \mathrm{v}$.

87 Baudry-Lacantinerie/Tissier, noot 78, 89. Paris, 3 janv. 1846, S. 47.2.77.

88 Baudry-Lacantinerie/Tissier, noot 78, 90. Cass., 10 août 1841, S. 41.1.740.

89 Deze wetten komen hieronder nog ter sprake.

90 Artikel 10 Loi du 30 mars 1887 sur les monuments historiques. Artikel 14 Loi du 31 décembre 1913 sur les monuments historiques. Deze wetten zien zowel op onroerend als roerend goed. Chatelain-Chatelain, noot 12, 51. El-Bitar, noot 13, $30 \mathrm{v}$.

91 Het zij nog opgemerkt dat de wetgever in 1820 een wet had uitgevaardigd die in verband met de invoering van artikel $2227 \mathrm{Cc}$ bepaalde dat iedere bezitter die een goed in strijd met het edict van Moulins van 1566 (domeingoederen zijn onvervreemdbaar) had verkregen na dertig jaar gerekend vanaf 1799 eigenaar was en dat de Staat de revindicatie niet meer kon instellen. Degene die het bezit had verkregen na de invoering van de Code civil viel in dezelfde categorie. Bezitters die een titel konden tonen en te goeder trouw waren konden na tien of twintig jaar verjaren. Deze laatste verjaringstermijnen duiden erop dat de wetgever alleen onroerend goed op het oog had. Les aliénations qui avaient été faites contrairement à l'ordonnance de 1566, (..). (..). La loi du 17 mars 1820 disposa que toute revendication de l'État serait éteinte après trente ans depuis la loi du 14 ventòse an VII (= 4 maart 1799). Ceux qui on aquis postérieurement au code civil des biens rentrant de cette catégorie on même pu les prescrire par dix ou vingt ans avec juste titre et bonne foi. Baudry-Lacantinerie/Tissier, noot 78, 111, 112. Zie ook: Troplong, noot 82, $312 \mathrm{v}$., die in deze geen onderscheid wil maken tussen privé- en publiek domeingoed. Zie voor de wettekst: Collection complète des Lois, Décrets, Ordonnances, Réglements avis au Conseil-d'État, 22, ed.: J.B. Duvergier, Parijs 1838, 400 v., artikel 9. 
VAN DER VEN, F.A.J.

\section{$2^{\mathrm{e}}$ mogelijke verweer: derdenbescherming ex artikel $2276 \mathrm{Cc}$.}

De overgrootvader had het beeld in 1813 van Baudot gekocht. Als we met de Staat aannemen dat Baudot beschikkingsonbevoegd was geweest, hetgeen niet ondenkbaar was, dan zou een beroep op derdenbescherming misschien uitkomst hebben geboden. De derdenbescherming staat in de Code civil geregeld in artikel $2276 \mathrm{Cc}$ : 'En fait de meubles, la possession vaut titre.' Artikel 2276 Cc komt overeen met artikel 2014 BW (oud). Oftewel: 'bezit geldt als volkomen titel'. Artikel $2276 \mathrm{Cc}$ biedt net als artikel 2014 BW en ons huidige artikel 3:86 BW bescherming aan de derde-bezitter te goeder trouw die op grond van een geldige titel een zaak heeft gekocht van een beschikkingsonbevoegde. ${ }^{92}$ De derde te goeder trouw wordt eigenaar. Heeft de eigenaar onvrijwillig het bezit verloren, dan verkrijgt de bezitter na drie jaar de eigendom. Hadden de zussen wellicht kunnen beweren dat hun overgrootvader op grond van artikel $2276 \mathrm{Cc}$ eigenaar was geworden en dat zij vervolgens door erfopvolging de eigendom hadden verkregen? Het artikel zou alleen van toepassing kunnen zijn indien hun vader te goeder trouw was geweest. De Fransen beschouwen de derdenbescherming als ogenblikkelijke verkrijgende verjaring ${ }^{93}$ en dan zou hetzelfde gelden als hetgeen hierboven over de verkrijgende verjaring ex artikel $2261 \mathrm{Cc}$ is gezegd. Ervan uitgaande dat het beeld publiek domeingoed was, dan zou artikel 2226 een beroep op verjaring en dus op derdenbescherming verhinderen. Volgens de huidige Code du patrimoine en de Code général de la propriété des personnes publiques zou een beroep op artikel $2276 \mathrm{Cc}$ evenmin kans van slagen hebben. De tweede casus moge een en ander verduidelijken.

\section{Casus tweede zaak. Het 'fragment met de adelaar'.}

\section{Inleiding}

De Staat kwam nog steviger in het zadel te zitten toen een half jaar na de einduitspraak in de zaak over Pleurant No 17 het Court de Cassation uitspraak deed in een soortgelijke zaak. Sinds dit oordeel is de kans dat particulieren de strijd tegen de Staat winnen nihil te noemen als het gaat om een kerkelijk cultuurgoed waarvan de Staat van mening is dat het op grond van het confiscatiedecreet van 1790 tot het publieke domein is gaan behoren. Op 13 februari 2019 deed de Franse cassatierechter een uitspraak naar aanleiding van de volgende casus. De feiten komen enigszins overeen met de feiten in de vorige zaak. Het is wederom een mooie zaak die garant stond voor een juridische soap die maar liefst zestien jaar heeft geduurd.

92 Terré-Simler, noot 50, par. $440 \mathrm{v}$.

93 Artikel 2258 Cc: La prescription acquisitive est un moyen d'acquérir un bien ou un droit par l'effet de la possession sans que celui qui l'allègue soit obligé d'en rapporter un titre ou qu'on puisse lui opposer l'exception déduite de la mauvaise foi. Jansen, noot 51, 207; Terré-Simler, noot 50, par. 440 v. 


\section{EEN TREURENDE MONNIK EN EEN ADELAAR}

In 2002 kocht de Parijse galerie en antiekhandel 'Brimo de Laroussilhe'94 een gebeeldhouwde steen van één meter zestig lang en achtenveertig centimeter hoog. Het bleek een onderdeel van het oksaal afkomstig uit de kathedraal van Chartres. Een oksaal of jubé is een stenen wand die in een kerk de scheiding vormt tussen het schip en het priesterkoor. Het heeft dezelfde functie als een koorhek. Het door Brimo gekochte onderdeel van het oksaal wordt 'het fragment met de adelaar' genoemd. Het is een zogeheten bas-reliëf en toont een adelaar die in steen is gebeeldhouwd en die slechts oppervlakkig uit het vlak naar voren komt.

De kathedraal van Chartres trof hetzelfde lot als het klooster Champmol te Dijon. Op grond van het decreet van 2 november 1790 confisqueerde de Assemblée nationale de kathedraal als kerkelijk goed. Met deze confiscatie zou eveneens het 'fragment met de adelaar' domeingoed zijn geworden. 'Brimo de Laroussilhe' kocht het fragment in 2002 om weer door te verkopen. Getuige zijn website heeft Brimo vele objecten afkomstig uit Franse kerken en kathedralen verkocht, zowel aan musea in Frankrijk als in het buitenland. ${ }^{95}$ Zo blijken het Louvre in Parijs, het Metropolitan Museum of Art in New York en het Louvre in Abu Dhabi vaste klanten. Er zullen ongetwijfeld ook particuliere afnemers zijn, maar die staan vanzelfsprekend niet op de site vermeld.

Toen Brimo de Minister een jaar later om een uitvoercertificaat vroeg, weigerde deze de afgifte van een certificaat met het argument dat het fragment een nationale schat was. Brimo probeerde nog met de Staat te onderhandelen. Hij vroeg twee komma drie miljoen euro, waarop de Staat een tegenbod van één miljoen euro deed. Deze onderhandeling liep op niets uit. De zaak had dus beëindigd kunnen worden, maar het resultaat was dat de Staat de revindicatie instelde. Experts taxeerden het fragment later tussen drie en zeven miljoen euro. Er volgde een wirwar aan procedures die begon bij de administratieve rechter. ${ }^{96}$ De Conseil Constitutionnel kwam er zelfs aan te pas, nadat Brimo bij het Court de Cassation in 2008 (of 2018) een zogeheten Question prioritaire de constitutionnalité had geformuleerd. Het Constitutionele Hof deed op 26 oktober 2018 uitspraak. ${ }^{97}$ Uiteindelijk is de zaak op 13 februari 2019 afgedaan met de uitspraak van het Court de Cassation. ${ }^{98}$

\section{Argumenten van partijen}

Brimo stelde in de eerste plaats dat het fragment al voor de confiscatie van de kerkelijke goederen uit de kerk was gehaald en dat het dus nooit op grond van het decreet van 2

94 Nicolas Brimo begon in 1908 als antiquair. Hij associeerde zich met zijn zwager Lucien Lascombes de Laroussilhe en zij stichten de kunsthandel Brimo Laroussilhe. In 1991 nam Philippe Carlier de zaak over. Zijn dochterzwaait inmiddels de scepterover de galerie. www.brimodelaroussilhe.com

95 www.brimodelaroussilhe.com

96 Tribunal administratif, (TA) 29 juni 2017, $\mathrm{n}^{\circ}$ 0707297/4-1. Te raadplegen via: www.paris.tribuna1administratif.fr; Cour administrative d'appèl, $(C A A) 29$ januari $2019 \mathrm{~N}^{\circ}$ 17PA02928. Te raadplegen via: www.legifrance.gouv.fr

97 Conseil Constitutionnel, 26 oktober 2018, nr. 2018-743 QPC. Te raadplegen via: www.conseilconstitutionnel.fr

98 Cour de Cassation, 13 februari 2019, n 18-13.748. Te raadplegen via: www.legifrance.gouv.fr 


\section{VAN DER VEN, F.A.J.}

november 1790 domeingoed was geworden. Een uitgebreide deskundigenrapportage volgde. ${ }^{99}$ Een paar opmerkingen.

Het stond vast dat het oksaal ooit in tweeën was geraakt. Het 'fragment met de adelaar' vormde de bovenste helft. Het andere deel is bewaard gebleven in de kathedraal van Chartres en is getiteld het 'fragment met de engel'. De twee panelen samengevoegd vertegenwoordigen 'het Lam Gods'. Volgens Brimo was het oksaal al in 1763 in tweeën gesplitst en was het fragment met de adelaar uit de kerk gehaald om te worden hergebruikt door een metselbedrijf. Volgens de deskundigenrapportage daarentegen was het profane gebruik van een gewijde steen buiten de kathedraal ondenkbaar. De rapportage liet verder zien dat de Minister de architect Lassus in 1848 de opdracht gaf in de kathedraal opgravingen te doen. Lassus vond toen het 'fragment met de engel' en nog een paar reliëfs. Alle fragmenten, dus ook het 'fragment met de adelaar', zouden na 1763, na de tweedeling van het oksaal, gebruikt zijn om de vloer van het koor in de kathedraal te plaveien en zouden daar nog tientallen jaren hebben gelegen. De beide fragmenten, de adelaar en de engel, vertoonden dezelfde sporen van slijtage van een tijdvak tussen zestig en tachtig jaren en waren gemaakt uit hetzelfde type hardsteen. Ze pasten precies in elkaar. De sporen van mortel die in 2008 op het 'fragment met de engel' waren aangetroffen kwamen overeen met die op het 'fragment met de adelaar'. Het betwiste 'fragment met de adelaar' zou volgens het rapport dus ook ooit ingemetseld zijn geweest op diezelfde plek in de vloer. Hoewel het precieze tijdstip waarop het fragment uit de kathedraal was gehaald niet kon worden achterhaald, moest er volgens de deskundige vanuit worden gegaan dat het in 1790 nog in de kathedraal aanwezig was. Een mogelijkheid die hij opperde was dat het na de brand in 1836 gestolen was. Of dat het bij de opgravingen in 1848 toch ook boven water was gekomen en daarna was verdwenen. Met deze conclusie was het één-nul voor de Staat. Het fragment was ten tijde van de confiscatie nog in de kathedraal aanwezig en dus als deel van de kerk domeingoed geworden. Hoe het fragment nu uiteindelijk in particuliere handen terecht was gekomen, was niet meer te achterhalen.

Brimo bracht verder ongeveer dezelfde argumenten tegen de Staat te berde als de drie zussen. Ook de argumenten van de Staat waren grotendeels gelijk. Zo beriep de Staat zich wederom op artikel L 3111-1 van de 'Code général de la propriété des personnes publiques': 'publieke domeingoederen zijn onvervreemdbaar en onverjaarbaar'. Brimo deed vervolgens een beroep op de verjaringsmogelijkheid ex artikel 36 van het decreet van 1790 .

Behalve op de verjaring ex artikel 36 van het Decreet van 1790, beriep Brimo zich op artikel 2276 Cc: 'En fait de meubles, la possession vaut titre.' Hij had het fragment verkregen van

$99 C A A$, noot 96. Zie hierover een kritisch artikel met allerlei hypothes es waarin de uitkomst van het rapport waar de rechter zich op verliet wordt betwijfeld. In dit artikel wordt gesuggereerd dat het fragment al voor 1789 uit de kerk verdwenen was. Didier Rykner, Jubé de Chartres : des hypothèses sont-elles des preuves?, in: La tribune de l'Art, 13 februari 2018, latribunedelart.com 


\section{EEN TREURENDE MONNIK EN EEN ADELAAR}

een beschikkingsonbevoegde, maar hij was volstrekt te goeder trouw geweest en dus op grond van genoemd artikel eigenaar geworden.

\section{Uitspraak in eerste en tweede aanleg}

Het Tribunal administratif en het Cour administrative d'appèl achtten artikel 36 van het decreet van 1790 niet van toepassing om dezelfde reden als in het geschil over Pleurant No 17. ${ }^{100}$ Het beroep van Brimo op derdenbescherming ex artikel $2276 \mathrm{Cc}$ werd eveneens afgewezen. $\mathrm{Nu}$ de verkrijging op grond van $2276 \mathrm{Cc}$ wordt opgevat als verkrijgende verjaring en domeingoederen door artikel L 3111-1 van de Code général de la propriété des personnes publiques van verjaring zijn uitgesloten was artikel $2276 \mathrm{Cc}$ dan ook niet van toepassing. De revindicatie werd toegewezen.

\section{Vraag voorgelegd aan het Constitutionele Hof}

Brimo formuleerde daarop de volgende constitutionele vraag die aan het Constitutionele Hof werd voorgelegd:

'Les dispositions de l'article L. 3111-1 (..), en ce qu'elles ne prévoient pas de dérogation pour les meubles corporels acquis de bonne foi, méconnaissent-elles les droits et libertés garantis par les articles 4 et 16 de la Déclaration des droits de l'homme et du citoyen?'101

Oftewel: miskennen de bepalingen van artikel L. 3111-1 (..), de rechten en vrijheden die worden gegarandeerd door de artikelen 4 en 16 van de Verklaring van de Rechten van de Mens en van de Burger, aangezien zij niet voorzien in een regeling ten behoeve van te goeder trouw verworven roerend goed? Kortom, is artikel L 3111-1 in strijd met de artikelen 6 en 14 van de Declaratie van 1789? Artikel 4 luidt als volgt:

La liberté consiste à pouvoir faire tout ce qui ne nuit pas à autrui: ainsi, l'exercice des droits naturels de chaque homme n'a de bornes que celles qui assurent aux autres membres de la société la jouissance de ces mêmes droits. Ces bornes ne peuvent être déterminées que par la loi.

De vrijheid bestaat daaruit, alles te kunnen doen wat een ander niet schaadt. Zo heeft de uitoefening van de natuurlijke rechten van ieder mens alleen deze grenzen die aan de andere leden van de maatschappij het genot van dezelfde rechten verzekeren. Deze grenzen kunnen alleen bij wet worden vastgelegd. En in artikel 16 lezen we het volgende:

Toute société dans laquelle la garantie des droits n'est pas assurée, ni la séparation des pouvoirs déterminée, n'a point de constitution.

100 TA, noot 96. CAA, noot 96.

101 Court de Cassation, arrest n 904, 5 september 2018 (18-13.748) ECLI:FR:CCASS:2018:C100904 (renvoi). Het Cour de Cassation gaf Brimo toestemming deze vraag voor te leggen aan het Constitutionele Hof. 


\section{VAN DER VEN, F.A.J.}

Iedere maatschappij waarin de rechten niet gewaarborgd zijn, noch de scheiding der machten is vastgelegd, heeft geen grondwet.

Volgens Brimo waren genoemde artikelen geschonden. De toewijzing van de revindicatie op grond van de Code général de la propriété des personnes publiques zou de garantie van verworven rechten aantasten. Hij was eigenaar geworden. Het principe van onvervreemdbaarheid maakte eigendomsoverdracht in het publieke domein onmogelijk; zonder toestemming was de verkoop nietig. En volgens het principe van onverjaarbaarheid kon een particulier na langdurig gebruik geen eigendom verkrijgen. De bepalingen in de Code général de la propriété des personnes publiques voorzagen niet in een afwijking van de beginselen van onvervreemdbaarheid en onverjaarbaarheid van domeingoederen ten gunste van de derde te goeder trouw. Brimo betwistte de absolute aard van de twee principes op grond van de rechtszekerheid. Doordat de bepalingen verkrijgers van domeingoed te allen tijde bloot stelden aan de revindicatie door de overheid, bedreigden deze bepalingen de veiligheid van transacties.'Het zou enerzijds leiden tot schending van het recht op bescherming van wettelijk verkregen posities en van het behoud van de wettelijke gevolgen die uit die posities voortvloeiden en anderzijds tot schending van het recht om rechtmatig gesloten overeenkomsten te handhaven.' 102

\section{Uitspraak Constitutioneel Hof}

Het Constitutionele Hof oordeelde op 26 oktober 2018 als volgt. ${ }^{103}$ In de eerste plaats vond het Hof dat geen enkel recht op eigendom van zaken in het publieke domein geldig kon worden gevormd ten voordele van derden. En in de tweede plaats dat dergelijke goederen niet waren onderworpen aan verkrijgende verjaring overeenkomstig artikel $2276 \mathrm{Cc}$, ten voordele van de opeenvolgende eigenaars, zelfs niet als zij te goeder trouw waren. De bescherming van het publieke domein vereiste dat de bestreden bepaling derogeerde aan de algemene regeling van artikel 2276 Cc. ${ }^{104}$ De inmenging van L 3111-1 die bestond uit de onvervreemdbaarheid van goederen en de onverjaarbaarheid van de revindicatie tegenover de bezitter te goeder trouw, streefde een legitiem doel na in het algemeen belang, zodat de

102 'La société requérante reproche à ces dispositions de ne pas prévoir de dérogation aux principes d'inaliénabilité et d'imprescriptibilité du domaine public en faveur des acquéreurs de bonne foi de biens mobiliers appartenant à ce domaine. En exposant ainsi ces acquéreurs, à tout moment, à une action en revendication de ces biens par les personnes publiques, ces dispositions menaceraient la «sécurité des transactions». Il en résulterait une méconnaissance, d'une part, du droit à la protection des situations légalement acquises et à la préservation des effets pouvant légitimement être attendus de telles situations et, d'autre part, du droit au maintien des conventions légalement conclues'. Conseil Constitutionel, noot 97. C. Delahousse, Les pricipes d'inaliénabilité et d'imprescriptibilité des biens du domaine public sontils conformes à la constitution?, 3-12-2018, eurojuris.fr

103 Conseil Constitutionel, noot 97.

104 'La protection du domaine public mobilier impose qu'il soit dérogé à la règle selon laquelle en fait de meubles, la possession vaut titre.' 'Afin d'assurer la protection du domaine public mobilier, les dispositions contestées dérogent à l'article 2276 du code civil relatif à la propriété des biens meubles relevant du droit commun, aux termes duquel $<$ En fait de meubles, la possession vaut titre $>$.' Conseil Constitutionel, noot 97. 


\title{
EEN TREURENDE MONNIK EN EEN ADELAAR
}

veroordeling van de bezitter om het litigieuze goed terug te geven niet disproportio nee 1 was. ${ }^{105}$

Voorts oordeelde het Hof dat het doel van onvervreemdbaarheid nu juist was om het verwerven van een recht te voorkomen en dat de toewijzing van de revindicatie dus niet tot doel had de huidige bezitter te beroven van een voorrecht dat hij nooit zou kunnen hebben gehad, maar om de echte eigenaar in zijn rechten te bevestigen. ${ }^{106}$

Over de artikelen 4 en 16 van de Declaratie van 1789 zei het Hof het volgende:

\begin{abstract}
'Het staat de wetgever, die binnen zijn bevoegdheid beslist, te allen tijde vrij om eerdere teksten te wijzigen of in te trekken doorze, indien nodig, te vervangen door andere bepalingen. Door dit te doen, kan hij echter niet de wettelijke garantie ontnemen die de grondwet eist. In het bijzonder kan hij zonder een voldoende algemeen belang noch de wettelijk verkregen posities ondermijnen, noch de gevolgen in twijfel trekken die op grond van de wet van deze posities worden verwacht. Evenzo zou hij niet voldoen aan de vereisten die voortvloeien uit de artikelen 4 en 16 van de Verklaring van 1789 als hij inbreuk maakte op wettelijk gesloten contracten, hetgeen door zo'n motief niet gerechtvaardigd is.' ${ }^{107}$
\end{abstract}

De regels van de Code général de la propriété des personnes publiques waren gemaakt om het publiek domein te beschermen en daarom weken de regels af van artikel $2276 \mathrm{Cc}$ en konden zelfs bezitters te goeder trouw geen beroep op dat artikel doen. De bestreden bepalingen van de zojuist genoemde Code général hadden geen invloed op wettelijk verworven rechten; evenmin maakten zij inbreuk op inmiddels gesloten overeenkomsten. De grieven betreffende de miskenning van de artikelen 4 jo 16 van de Verklaring van 1789 werden dan ook afgewezen. De bestreden bepalingen makten geen inbreuk op enig ander recht of op de door de Grondwet gegarandeerde vrijheid, en daarom waren ze met de Grondwet in overeenstemming. ${ }^{108}$

105 'L'ingérence que constituent l'inaliénabilité du bien et l'imprescriptibilité de l'action en revendication à l'égard du possesseur de bonne foi poursuit un but légitime relevant de l'intérêt général de telle sorte que la condamnation du possesseur à restituer le bien litigieux ne saurait être disproportionnée.' Conseil Constitutionel, noot 97.

106 'Sauf que, précisément, le Conseil constitutionnel souligne que l'objet de l'inaliénabilité est de faire échec à l'acquisition d'un droit et qu'en conséquence, l'action n'a pas pour objet de priver l'actuel possesseurd'une prérogative qui n'a jamais pu être la sienne mais de confirmer le véritable propriétaire dans ses droits. ' N. Le Rudulierle, Revendication du fragment à l'Aigle de la cathédrale de Chartres, 1 maart 2019, dalloz-actualite.fr

107 'Il est à tout moment loisible au législateur, statuant dans le domaine de sa compétence, de modifier des textes antérieurs ou d'abroger ceux-ci en leur substituant, le cas échéant, d'autres dispositions. Ce faisant, il ne saurait toutefois priver de garanties légales des exigences constitutionnelles. En particulier, il ne saurait, sans motif d'intérêt général suffisant, ni porter atteinte aux situations légalement acquises ni remettre en cause les effets qui peuvent légitimement être attendus de telles situations. De même, il ne respecterait pas les exigences résultant des articles 4 et 16 de la Déclaration de 1789 s'il portait aux contrats légalement conclus une atteinte qui ne soit justifiée par un tel motif.' Conseil Constitutionel, noot 97.

108 'Il résulte de ce qui précède, d'une part, qu'aucun droit de propriété sur un bien appartenant au domaine public ne peut être valablement constitué au profit de tiers et, d'autre part, qu'un tel bien ne peut faire 


\section{VAN DER VEN, F.A.J.}

\section{Cour de Cassation}

Het Cour de Cassation voegde aan het bovenstaande het volgende toe. ${ }^{109}$ Het betrof het oordeel over het beroep van Brimo op artikel 1 van het eerste aanvullende protocol bij het Europees Verdrag tot Bescherming van de Rechten van de Mens. Voor het gemak herhalen we de tekst van artikel 1:

1-Iedere natuurlijke of rechtspersoon heeft recht op het ongestoord genot van zijn eigendom. Aan niemand zal zijn eigendom worden ontnomen behalve in het algemeen belang en onder de voorwaarden voorzien in de wet en in de algemene beginselen van internationaal recht.

2-De voorgaande bepalingen tasten echter op geen enkele wijze het recht aan, dat een Staat heeft om die wetten toe te passen, die hij noodzakelijk oordeelt om het gebruik van eigendom te reguleren in overeenstemming met het algemeen belang (..).

De revindicatie tot teruggave van het goed was, aldus Brimo, gericht tot een persoon die, nadat hij een goed te goeder trouw had verkregen, een gewettigd vertrouwen koesterde om het goed te behouden of een tegenprestatie te krijgen. De rechter bevestigde dat dit gerechtvaardigd vertrouwen dat gebaseerd was op artikel 2276 Code civil viel onder de bescherming van artikel 1. Maar de Staat had met het uitvaardigen van de regels van de Code général de la propriété des personnes publiques een inbreuk mogen maken op dit vertrouwen en dus op artikel $2276 \mathrm{Cc}$ aangezien de bescherming van het publieke domein in het algemeen belang was geweest. Deze wettelijke regels in deze Code général boden de door het verdrag vereiste toegankelijkheid, duidelijkheid en voorspelbaarheid. ${ }^{110}$

Aangezien de revindicatie de enige maatregel was die de Staat kon gebruiken om in het bezit hersteld te worden, was deze actie niet onevenredig in het licht van het legitieme doel

l'objet d'une prescription acquisitive en application de l'article 2276 du code civil au profit de ses possesseurs successifs, même de bonne foi. Dès lors, les dispositions contestées ne portent pas atteinte à des situations légalement acquises, ni ne remettent en cause les effets qui pourraient légitimement être attendus de telles situations. Elles ne portent pas davantage atteinte aux conventions légalement conclues. Les griefs tirés de la méconnaissance des articles 4 et 16 de la Déclaration de 1789 doivent donc être écartés.' 'Par conséquent, les dispositions contestées, qui ne méconnaissent aucun autre droit ou liberté que la Constitution garantit, doivent être déclarées conformes à la Constitution.' Conseil Constitutionnel, noot 97.

109 Cour de Cassation, noot 98.

110 'Attendu, cependant, que l'ingérence que constituent l'inaliénabilité du bien et l'imprescriptibilité de l'action en revendication est prévue à l'article L. 3111-1 du code général de la propriété des personnes publiques, dans sa rédaction issue de l'ordonnance $n^{\circ} 2006-460$ du 21 avril 2006 relative à la partie législative du même code; qu'il s'en déduit qu'aucun droit de propriété sur un bien appartenant au domaine public ne peut être valablement constitué au profit de tiers et que ce bien ne peut faire l'objet d'une prescription acquisitive en application de l'article 2276 du code civil au profit de ses possesseurs successifs, même de bonne foi ; que ces dispositions législatives présentent l'accessibilité, la clarté et la prévisibilité requises par la Convention; Attendu que cette ingérence poursuit un but légitime, au sens de l'article ler du premier protocole additionnel à la Convention de sauvegarde des droits de l'homme et des libertés fondamentales, dès lors que la protection de l'intégrité du domaine public relève de l'intérêt général;' Cour de Cassation, noot 98. Le Rudulierle, noot 106. 


\section{EEN TREURENDE MONNIK EN EEN ADELAAR}

dat artikel 1 nastreeft. ${ }^{111}$ De rechter voegde er echter aan toe dat de veroordeling van Brimo om het goed terug te geven zonder vergoeding - a priori - een onevenredigheid zou opleveren. $_{112}$ Maar er was geen sprake van schending van de rechtszekerheid en van verworven rechten. Van een gewettigd vertrouwen om de eigendom te behouden was geen sprake. ${ }^{113}$

Wederom zegevierde het publieke belang. Hoe hoog de vergoeding aan Brimo is uitgevallen is mij niet bekend. Toen Brimo in 2003 de exportvergunning werd geweigerd en de Staat het beeld opeiste heeft de Staat, zoals gezegd, nog met Brimo onderhandeld. De Staat bood Brimo toen één miljoen euro.

\section{Conclusie}

In Frankrijk is het voor zowel de koper als de verkoper oppassen geblazen als hij een religieus kunstobject koopt dan wel verkoopt. Uit het niets kan de Staat opduiken en met succes de zaak revindiceren. De handel in kunstobjecten, afkomstig uit kerken en kathedralen, heeft met deze twee arresten een flinke klap gekregen. Bij dit soort kunstobjecten kan de Staat immers steeds zeggen dat het sinds de Franse revolutie domeingoed is en dus eigendom is van de Staat. Van de Déclaration des droits de l'homme et du citoyen van 1789 en van het EVRM van 1953 hoefden partijen niets te verwachten. Zowel de declaratie als het verdrag hebben hun wortels in het natuurrecht en beloven met mooie frasen privé-eigendom als groot goed te beschermen. Maar in de praktijk leek niets minder waar. Waar het aankwam op de belangenafweging sloeg de weegschaal door in het voordeel van het publieke belang. De verjaringsbepalingen van de Code civil werden door de rechter met een beroep op het EVRM buiten werking gezet, terwijl de vraag wie eigenaar was, beantwoord moest worden aan de hand van de regels van het stellige recht en niet aan de hand van de natuurrechtelijke billijkheid, want dat is, zoals Vitringa in zijn vertoog tegen Schorer in 1777 opmerkte 'een wassche neus, welken men kan draayen, keeren en wenden, hoe men wil'. ${ }^{114}$

Zoals gezegd heeft Brimo de Laroussilhe in de loop der tijd vele van dit soort objecten verkocht aan vooraanstaande musea over de hele wereld. Ook de zussen boden hun Pleurant aan bij een gerenommeerd veilinghuis. Het gevaar is dat de handel in dit soort kunst zich voortaan in achterkamertjes gaat afspelen als gevolg waarvan de objecten voorgoed aan het

111 'L'action en revendication étant la seule mesure de nature à permettre à l'État de recouvrer la plénitude de son droit de propriété, l'ingérence ne saurait être disproportionnée eu égard au but légitime poursuivi'. Courde Cassation, noot 98.

112 'Or, ajoute le juge judiciaire, ordonner à la société la restitution du bien sans indemnisation matérialiserait bien - a priori - une telle disproportion. 'Cour de Cassation, noot 98.

113 'Ainsi, pour le juge du droit, il n'y a pas d'atteinte à la sécurité juridique et aux droits acquis puisque (..). Il en résulte pour la première chambre civile que "l'espérance légitime » (..) de conserver le bien peut en l'espèce être écartée. 'Le Rudulierle, noot 106.

114 L. J. Vitringa, De eer der Hollandsche natie, Den Haag 1777, 104. 


\section{VAN DER VEN, F.A.J.}

publieke oog worden onttrokken.

Musea zijn overigens voorzichtiger geworden belangrijke cultuurgoederen te kopen. Vroeger waren musea voornamelijk bezorgd over de echtheid, maar nu zijn ze meer gespitst op de herkomst. Toch gaat het hier en daar mis, zoals in New York in 2017, toen het Metropolitan Museum of Art - in het jargon 'de Met' - van de Franse kunsthandelaar Christophe Kunicki een gouden sarcofaag voor drieënhalf miljoen dollar op de kop tikte die gestolen bleek te zijn. Tijdens een tentoonstelling in 2018 waarbij de sarcofaag het middelpunt vormde, ging het balletje rollen en werd duidelijk dat de exportpapieren waarmee de sarcofaag Egypte in 1971 had verlaten waren vervalst. De sarcofaag zou verschillende malen zijn doorverkocht aan privé-collectionneurs totdat de kist uiteinde lijk in handen van Kunicki was gekomen. In werkelijkheid was de sarcofaag tijdens de 'Arabische Lente' in 2011 gestolen uit de stad Minya bij de dodenvallei langs de Nijl. Een internationale bende smokkelde de sarcofaag via Dubai en Duitsland naar Parijs. Inmiddels is de kist terug in Egypte.115 Het Museum heeft bij Kunicki een vordering tot schadevergoeding ingediend. Kunicki heeft volgens zijn website nog een hoofd van Apollo in de aanbieding. 116

\section{Code du patrimoine}

Het is wederom een theoretische vraag, maar gesteld dat de rechter de revindicatie in beide gevallen had afgewezen, hadden de zussen en Brimo de goederen, die in dat geval dus geen domeingoederen waren, maar wel van nationaal belang, dan aan 'Jan en Alleman' mogen verkopen?

\section{Trésors nationaux}

We hebben gezien dat sinds 1887 de mogeliikheid bestaat dat de Franse overheid cultuurgoederen 'classeert' of in termen van onze Erfgoedwet 'aanwiist'. Volgens de huidige Code du patrimoine moeten het goederen zijn waarvan het algemeen belang eist dat zij vanuit het oogpunt van de geschiedenis, de kunst, de wetenschap of de techniek bewaard blijven. ${ }^{117}$ Classering kan op verzoek of ambtshalve geschieden. Het goed gaat na classering behoren tot de trésors nationaux, waartoe onder andere ook de goederen behoren die deel uitmaken van de nationale collecties en de collecties van de musea van Frankrijk, de collections des Musées de France. ${ }^{118}$ Export van deze goederen is niet toegestaan. De

115 E. van Zwam, Metropolitan Museum diep door het stof vanwege aankoop gestolen gouden sarcofaag, Trouw, 26 september 2019.

116 kunicki.eu

117 Artikel L 622-1 Code du patrimoine: Les objets mobiliers, soit meubles proprement dits, soit immeubles par destination, dont la conservation présente, au point de vue de l'histoire, de l'art, de la science ou de la technique, un intérêt public peuvent être classés au titre des monuments historiques par décision de l'autorité administrative. El-Bitar, noot 13, $31 \mathrm{v}$.

118 In artikel L 111-1 Code du patrimoine staat welke goederen als nationale schatten worden beschouwd: Les biens appartenant aux collections publiques et aux collections des musées de France, les biens 


\section{EEN TREURENDE MONNIK EN EEN ADELAAR}

goederen mogen alleen tijdelijk en voor een bepaald doel de grens over worden gebracht, bijvoorbeeld voor restauratie of voor een cultureel evenement. ${ }^{119}$ De criteria voor classering zijn de zeldzaamheid van het goed, de bekendheid van de kunstenaar of de herkomst uit een bepaald tijdperk. Nationaliteit is geen criterium. Ook kunstwerken uit het buitenland komen voor classering in aanmerking. ${ }^{120}$ Het uitgangspunt is dat classering geschiedt met toestemming van de eigenaar. ${ }^{121}$ Classering kan echter ook tegen de wil van de eigenaar plaatsvinden. De eventuele schade die de eigenaar door de aanwijzing lijdt moet worden vergoed. ${ }^{122}$ Deze schade kan onder andere het gevolg zijn van het verbod van export naar het buitenland. Het goed kan in dat geval niet op de internationale kunstmarkt worden aangeboden. De hoogte van de schade is het verschil in de opbrengst bij verkoop op de internationale markt en de opbrengst die het goed oplevert op de nationale markt. Komen partijen niet tot overeenstemming, dan bepaalt de rechter de hoogte van de vergoeding.

De Code $d u$ patrimoine legt de eigenaar van een geclasseerd goed eveneens onderhoudsverplichtingen op waaraan onder streng toezicht van de overheid moet worden voldaan. ${ }^{123}$ Van de classering wordt overigens weinig gebruik gemaakt. De reden is de hoogte van de vergoeding die de overheid moet betalen. Zo oordeelde het Cour de Cassation in 1996 dat de overheid uiteindelijk aan een eigenaar van een schilderij van Van Gogh honderdvijfenveertig miljoen Franse francs (dit is tweeëntwintig miljoen euro) moest betalen. ${ }^{124}$ Veelal is het voor de Staat in zo'n geval zinvoller om het goed voor de openbare verzamelingen te verwerven, zodat het toegankelijk wordt voor het publiek. Geeft de Staat 'slechts' een vergoeding, dan bestaat de kans dat het kunstwerk voor het publiek 'verborgen' blijft als de eigenaar het niet ten toon wil stellen.

Het voordeel van de classering voor de eigenaar is dat het goed niet voor verjaring vatbaar is. ${ }^{125} \mathrm{Hij}$ kan tegen iedere bezitter, dus ook tegen de bezitter te goeder trouw, zonder

classés en application des dispositions relatives aux monuments historiques et aux archives, ainsi que les autres biens qui présentent un intérêt majeur pour le patrimoine national au point de vue de l'histoire, de l'art ou de l'archéologie sont considérés comme trésors nationaux. El-Bitar, noot 13, 34 en 58. Artikel L 441-1

119 El-Bitar, noot 13, 34. Artikel L 111-7 Code du patrimoine: L'exportation des trésors nationaux hors du territoire douanier peut être autorisée, à titre temporaire, par l'autorité administrative, aux fins de restauration, d'expertise, de participation à une manifestation culturelle ou de dépôt dans une collection publique.

120 El-Bitar, noot 13, 32; Poli, noot 12, 127 v.

121 Artikel L 622-4 Code du patrimoine: Les objets mobiliers appartenant à une personne privée peuvent être classés au titre des monuments historiques, avec le consentement du propriétaire, par décision de l'autorité administrative, après avis de la Commission nationale du patrimoine et de l'architecture. Zie hierover El-Bitar, noot 13, $31 \mathrm{v}$.

122 Artikel L 622-4: A défaut de consentement du propriétaire, le classement d'office est prononcé par un décret en Conseil d'Etat pris après avis de la Commission nationale du patrimoine et de l'architecture. Le classement pourra donner lieu au paiement d'une indemnité représentative du préjudice résultant pour le propriétaire de l'application de la servitude de classement d'office. El-Bitar, noot 13, 37.

123 Artikel 622-7 Code du patrimoine.

124 Cour de cassation, Civ. 1er, 20.2. 1996 (Agent judiciairedu Trésor C. Walter), D. 1996, jurisprudence, 511 f. El-Bitar, noot 13, 34, 37, noot 110.

125 Artikel L 622-13 Code du patrimoine: Tous les objets mobiliers classés au titre des monuments historiques sont imprescriptibles. El-Bitar, noot 13, 34, 35. 


\section{VAN DER VEN, F.A.J.}

tijdslimiet met succes de revindicatie instellen. ${ }^{126}$ De geclasseerde goederen die eigendom zijn van de Staat behoren tot het domaine public en zijn, zoals gezegd, res extra commercium. Behalve dat ze niet voor verjaring vatbaar zijn, kunnen ze ook niet worden vervreemd. ${ }^{127}$ Daarentegen mag een geclasseerd goed door een private eigenaar wel binnen Frankrijk worden vervreemd. De voorwaarde is dat hij op straffe van een boete de classering aan de nieuwe eigenaar meedeelt. ${ }^{128}$ Besluit de eigenaar het goed in Frankrijk op een veiling aan te bieden, dan heeft de Staat op de veiling een voorkeursrecht, een droit de préemption. ${ }^{129}$ Dit recht heeft de Staat overigens bij alle culturele goederen. Na de laatste hamerslag op de veiling kan de Staat het betreffende cultuurgoed tegen betaling van de gerealiseerde veilingprijs verwerven. ${ }^{130}$ De Staat wordt gesubrogeerd in de rechten van de koper. De minister kan goederen op verzoek van de eigenaar of ambtshalve 'declasseren'. ${ }^{131}$

126 Zie ook hierboven noot 58. Dit geldt ook voor voor internationale rechtsvorderingen. Artikel 8 van de Richtlijn 2014/60/EU van 15 mei 2014 betreffende de teruggave van cultuurgoederen die op onrechtmatige wijze buiten het grondgebied van een lidstaat zijn gebracht en houdende wijziging van Verordening (EU) nr. 1024/2012. Frankrijk kan zijn nationale cultuurgoed onbegrensd in tijd terugvorderen, nu de nationale regeling onverjaarbaarheid voorschrijft. El-Bitar, noot 13, 130. Deze richtlijn is in artikel L 112-1 de Code du patrimoine geimplementeerd: L'action tendantau retour d'un bien culturel est prescrite à l'expiration d'un délai de trois ans à compter de la date à laquelle l'autorité centrale compétente de l'Etat membre a eu connaissance du lieu où se trouve ce bien et de l'identité de son propriétaire, de son possesseur ou de son détenteur. En tout état de cause, l'action se prescrit dans un délai de trente ans à compter de la date à laquelle le bien culturel est sorti illicitement du territoire de l'Etat membre requérant. Toutefois, l'action se prescrit dans un délai de soixante-quinze ans, ou demeure imprescriptible si la législation de l'Etat membre requérant le prévoit, pour les biens inventoriés dans les collections publiques, ainsi que pour les biens figurant sur les inventaires des autorités ecclésiastiques, lorsque la loi de l'Etat membre requérant accorde à ces biens une protection spécifique.

127 El-Bitar, noot 13, 35 en 49. Artikel L 624-14 Code du patrimoine: Les objets classés au titre des monuments historiques appartenant à l'Etat sont inaliénables. Geclasseerde goederen die privéeigendom zijn van een departement, gemeente of een andere publieke instelling mogen wel worden vervreemd, maar alleen aan de Staat of een publieke instelling en na toestemming van de minister van cultuur. Op deze wijze wordt ongecontroleerde verkoop van geclasseerde cultuurgoederen verhinderd. Onvervreemdbaar zijn ex artikel L 451-5 de 'collections des musées de France', die toebehoren aan een publiek lichaam; zij vallen onder het publiek domein. Zij zijn volgens artikel L 541-3 evenmin voor verjaring vatbaar. De goederen die toebehoren aan 'personnes morales de droit privé à but non lucratif', bijvoorbeeld stichtingen, die zich wel 'Musées de France' mogen noemen, maar wier eigenaar geen overheidslichaam is, mogen wel worden overgedragen, anders zou dat een te grote inbreuk op het eigendomsrecht zijn. Uitgezonderd echter zijn die goederen die door schenking, legaat of met steun van de overheid zijn verkregen. Deze mogen ex artikel L 541-10 alleen worden overgedragen aan een overheidsinstelling of een stichting. De verzamelingen zijn niet voor verjaring vatbaar.

128 Artikel L 622-16 Code du patrimoine: Tout particulier qui aliène un objet classé au titre des monuments historiques est tenu de faire connaître à l'acquéreur l'existence du classement. El-Bitar, noot 13, 36.

129 Artikel L 123-1 e.v. Code du patrimoine: L'Etat peut exercer, sur toute vente publique d'oeuvres d'art ou sur toute vente de gré à gré d'œuvres d'art réalisée dans les conditions prévues par l'article L. 321 9 du code de commerce, un droit de préemption par l'effet duquel il se trouve subrogé à l'adjudicataire ou à l'acheteur.

130 'Van terughoudend naar betrokken', rapport commissie Pechtold, noot 6, 119

131 Artikel L 622-6 Code du patrimoine: Le déclassement d'un objet mobilier classé au titre des monuments historiques peut être prononcé par l'autorité administrative soit d'office, soit à la demande du propriétaire. El-Bitar, noot 13, 33. 


\section{EEN TREURENDE MONNIK EN EEN ADELAAR}

Frankrijk heeft een naam op het gebied van de bescherming van cultureel erfgoed, met name waar het de bescherming van de trésors nationaux betreft. De kritiek die echter wel wordt gehoord is dat er tot nu toe geen duidelijk centraal register is aangelegd, dat zowel de geclasseerde goederen, de archieven als ook de beschermde verzamelingen in de musea omvat. Het blijft voor de burger weinig overzichtelijk, hetgeen een nadeel is voor de particuliere verzamelaar die probeert informatie over een bepaald voorwerp in te winnen om zo veel mogelijk het risico van bijvoorbeeld een exportbeperking te vermijden. ${ }^{132}$

\section{Biens culturels}

Goederen die (nog) niet zijn geclasseerd, maar die wel een historisch, artistiek of een archeologisch belang vertegenwoordigen, behoren tot de categorie biens culturels. Deze goederen mogen wel worden geëxporteerd, doch ook voor deze goederen geldt dat de eigenaar eerst 'langs' de minister moet. De eigenaar heeft voor export namelijk een certificaat van de minister nodig. ${ }^{133}$ De eigenaar moet zelf inschatten of hij een certificaat moet aanvragen. Deze inschatting moet hij maken op grond van de geschatte waarde van het object; in een aanhangsel van de Code du patrimoine worden de waardelimieten genoemd. Moet de eigenaar een certificaat aanvragen en wordt hem het certificaat verleend, dan betekent dat dat het goed definitief geen trésor national is en dus mag worden uitgevoerd. De Minister weigert het certificaat af te geven als hij op advies van de twaalfkoppige Commission consultative des trésors nationaux concludeert dat het om een trésor national gaat. Geïnspireerd door het Engelse systeem heeft de Staat krachtens de wet vervolgens het recht van koop ten behoeve van de openbare collecties. ${ }^{134}$ Bij de vaststelling van de koopsom wordt rekening gehouden met de prijzen op de internationale markt. Beide partijen mogen deskundigen benoemen die de prijs bepalen. Komen partijen niet tot overeenstemming, dan kunnen ze een beroep doen op de rechter. Accepteert de eigenaar het uiteindelijke vastgestelde bedrag niet, dan kan het besluit tot weigering van de vergunning worden verlengd, zonder dat er een vergoeding van het nadeel voor de eigenaar tegenover staat. De verlenging van de weigering van de vergunning is voor de eigenaar als het ware een sanctie voor het feit dat hij het aanbod van de Staat heeft afgewezen. Het risico op verlenging van de weigering zonder dat er een vergoeding tegenover staat is voor de eigenaar een stok achter de deur om toch maar het bod van de Staat te accepteren. De Staat heeft hiermee een pressiemiddel in handen. Krijgt de eigenaar geen certificaat, dan kan hij het goed niet naar het buitenland exporteren. Verkoopt en levert hij het goed vervolgens binnen Frankrijk, dan moet hij de koper mededelen dat er geen exportvergunning afgegeven

132 El-Bitar, noot 13, 227.

133 Artikel L 111-2 Code du Patrimoine: L'exportation temporaire ou définitive hors du territoire douanier des biens culturels, autres que les trésors nationaux, qui présentent un intérêt historique, artistique ou archéologique et entrent dans l'une des catégories définies par décret en Conseil d'Etat est subordonnée à l'obtention d'un certificat délivré par l'autorité administrative. El-Bitar, noot 13, 57 en $61 \mathrm{v}$.

134 Artikel L 121-1 Code du patrimoine: Dans le délai de trente mois prévu à l'article L. 111-6, l'autorité administrative peut, dans l'intérêt des collections publiques, présenter une offre d'achat. Cette offre tient compte des prix pratiqués sur le marché international. El-Bitar, noot 13, $65 \mathrm{v}$. Ten overvloede zij opgemerkt dat dit niet geldt in het gevalvan Pleurant No 17 omdat het beeld eigendom was van de Staat. 


\section{VAN DER VEN, F.A.J.}

is en, indien de Staat een bod heeft gedaan, hem van dat bod op de hoogte stellen. ${ }^{135}$ Laat hij dat na, dan is de koop nietig. ${ }^{136}$ Omdat naar Frans recht bij het totstandkomen van de koopovereenkomst tevens de eigendom overgaat ${ }^{137}$ treft de nietigheid van de koop ook de eigendomsoverdracht. Het voordeel van de strenge uitvoercontrole is voor kunsthandelaren dat zij, indien een certificaat wel is afgegeven, een toekomstige koper de garantie kunnen geven dat het goed buiten de grenzen van Frankrijk vrij verhandelbaar is. ${ }^{138}$

Hoewel de Franse wetgeving het eigendomsrecht van cultureel erfgoed sterk aan banden legt, biedt het de eigenaar door de onverjaarbaarheid een goede bescherming.

De kans dat belangriik erfgoed op legale wijze naar het buitenland kan worden verkocht is klein. Als het een door de overheid geclasseerd goed betreft, dan is export niet toegestaan. Is het een bien culturel, dan heeft de eigenaar voor export een certificaat nodig, dat kan worden geweigerd. De overheid heeft het laatste woord.

\section{Nederlands recht}

\section{Erfgoedwet}

\section{Inleiding}

In 1873 schreef Victor de Stuers, zoals gezegd, zijn artikel getiteld 'Holland op zijn smalst' waarin hij grote zorgen uitte over de behandeling van het culturgoed in Nederland:

\footnotetext{
'Om den toestand te bestempelen waarin hier te lande de monumenten van kunst en historie verkeeren, is zeker het woord 'ellendig' niet onjuist gekozen, zoodat men met recht op dit gebied mag spreken van Holland op zijn smalst. (..) Wij leven in weelde: Indië brengt millioenen op; de Indische overschotten vallen als een gestadige manna over ons neder; wij voeren oorlog met hetgeen de koffie boven de raming opbrengt; de middelen hier te lande leveren jaarlijks hoogere inkomsten.... maar als het geldt een voorwerp van nationale kunst te bewaren en te verzorgen, houden wij de beurs gesloten!'139
}

Hij trok fel van leer tegen Monumentenzorg, de Rijksbouwkunst en de musea. In zijn

135 Artikel L 121-3 Code du patrimoine: Tout propriétaire qui aliène un bien culturel mentionné à l'article L. 121-2 est tenu, à peine de nullité de la vente, de faire connaître à l'acquéreur l'existence du refus de délivrance du certificat, mentionné à l'article L 111-4 et, le cas échéant, les offres d'achat adressées dans les conditions prévues à l'article L. 121-1.

136 El-Bitar, noot 13, 66. Artikel L 121-4 Code du patrimoine: Est nulle toute aliénation du bien consentie par le propriétaire ou ses ayants cause après avoir accepté une offre d'achat adressée par l'autorité administrative dans les conditions prévues à l'article L 121-1. L'action en nullité se prescrit par six mois à compter du jour où l'autorité administrative a eu connaissance de la vente. Elle ne peut être exercée que parl'autorité administrative.

137 Terré, Simler, noot 50, par. 378 v.; Zwalve, noot 44, 281 v.

138 El-Bitar, noot 13, 228.

139 De Stuers, noot 3, 327/373. 


\section{EEN TREURENDE MONNIK EN EEN ADELAAR}

pamflet gaf De Stuers talloze voorbeelden van gebouwen en kunstvoorwerpen die teloor waren gegaan. Net als in Chartres was in de St Janskerk te 's Hertogenbosch het prachtige oksaal gesloopt. De bisschop had daartoe de opdracht gegeven en het oksaal of jubé werd in dagbladen te koop aangeboden. 'Dat men het jubé aan de Nederlandsche Regeering niet te koop aanbood, mogen wij waarlijk den bisschop niet euvel duiden' ${ }^{140}$, aldus De Stuers. 'Want men zou toch van het aanbod geen gebruik hebben gemaakt. Kunst immers heette tot voor twee jaren geen regeeringszaak, en bij dit sophisme legde zich het Nederlandsche volk met kalmte en gelatenheid neder. ${ }^{141}$ Later ontdekte De Stuers het oksaal in een museum in Engeland:

'Ik kon bijna niet gelooven, dat hetgeen ik zag in werkelijkheid voor mij stond, en toen een opzichter naar mij toetrad, en mij een catalogus (kosteloos nog wel) aanbood, waarin ik een beschrijving kon vinden van het 'most magnificent Dutch monument', gevoelde ik mij diep vernederd, en was ik angstig dat men mij vragen zou of ik Nederlander was.' ${ }^{142}$

De Stuers pleitte er, zoals gezegd, dan ook voor dat de overheid ingreep, want van de samenleving viel niet veel te verwachten.

Bussemaker zei in 2016 ongeveer hetzelfde toen ze over de verkoop van 'Marten en Oopien' aan De Rothschild in 1878 zei dat deze verkoop aantoonde 'dat Nederland was "vervreemd van zijn eigen aard". 'Buitenlandse kunstkenners entameerden de waardering voor de grote zeventiende-eeuwers, niet de Nederlanders zelf.' ${ }^{143}$

Het zij tussendoor opgemerkt dat, toen aan het eind van de achttiende- en het begin van de negentiende eeuw de grote musea in West-Europa en de Verenigde Staten hun deuren openden, deze musea voor een groot deel zijn 'gevuld' met kunst die in de hele wereld was 'verzameld, gekocht, geplunderd of geroofd.' ${ }^{144}$ Bekende voorbeelden zijn de Elgin Marbles in het British Museum, de buste van Nefertiti in het Neues Museum en De Venus van Milo in het Louvre. ${ }^{145}$ De verschillende musea zijn regelmatig lastiggevallen met restitutieclaims, maar tot op heden zijn deze claims niet erg succesvol gebleken. De persvoorlichter van het Louvre zou ooit hebben gezegd, 'Maar wie zou er geïnteresseerd zijn in Griekse sculpturen als die zich allemaal in Griekenland zouden bevinden? Deze stukken zijn groots omdat ze in het Louvre staan.' ${ }^{146}$

140 De Stuers, noot 3, 372.

141 De Stuers, noot 3, 372.

142 De Stuers, noot 3, 372.

143 Kleijn, noot 2.

144 E. Taal, Roofkunst en rechtvaardigheid, De Elgin Marbles als voorbeeld van een moreel dilemma, Masterthes is Kunstgeschiedenis UU, 2011, 88. Deze scriptie is te vinden op het internet. Taal verwijst veelvuldig naar: S. Waxman, Loot. The Battle over the Stolen Treasures of the Ancient World, New York 2008, 91.

145 In februari jl. dook een bericht op dat de Elgin Marbles onderwerp zijn in een EU-document bestemd voor onderhandelingen over de handel met Londen. Het nieuwe handelsakkoord zou bepalen dat 'onwettig verwijderde culturele objecten zouden worden teruggegeven aan het land van herkomst'. Trouw, 19 februari 2020. De Engelse reactie laat zich raden.

146 Overgenomen van Taal, noot 144, 88. 


\section{VAN DER VEN, F.A.J.}

Nederland leek zich vorig jaar van zijn goede kant te laten zien, waar het ging om teruggave van koloniaal erfgoed. Zo was het Rijksmuseum, volgens een bericht in Trouw, van plan een kanon terug te geven dat VOC-troepen op Ceylon in 1765 hadden buit gemaakt op de koning van Kandy. Sri Lanka had in 1980 overigens al eens om teruggave gevraagd. Hoewel er een prent bestaat waarop duidelijk te zien is dat het kanon als 'symbool voor het nieuwe Nederland, een wereldmacht die rijk was geworden met handel' het gebouw van de StatenGeneraal wordt binnengedragen ${ }^{147}$, meende het Rijksmuseum dat ter plekke meer onderzoek nodig was om vragen naar de herkomst op te helderen. Onderzoek alleen in Amsterdam zou niet voldoende zijn .... Hetzelfde gold voor een diamant van de sultan van Borneo die geroofd was nadat Nederlandse troepen in 1859 het sultanaat met geweld hadden ingeno men en opgeheven. Taco Dibbits merkte op: 'Het is niet mogelijk om de zaken vanuit Nederland te regelen. Je moet met de mensen dáár om tafel gaan zitten, het per geval bekijken.' ${ }^{148}$ Inmiddels is de 'Commissie Nationaal Beleidskader Koloniale Collecties' ingesteld die begin oktober haar advies aan de Minister presenteerde. ${ }^{149}$

$\mathrm{Na}$ de kritiek van De Stuers in de negentiende eeuw werd binnen het Ministerie van Binnenlandse Zaken de afdeling Kunsten en Wetenschappen opgericht, waar De Stuers de scepter ging zwaaien. Eerst in 1985 kwam met de Wet Behoud Cultuurbezit (Wbc) een wettelijke regeling tot stand, die onder andere moest voorkomen dat voor Nederland belangrijke kunstwerken, die zich in particuliere handen bevonden naar het buitenland verdwenen. In 2016 is deze wet vervangen door de Erfgoedwet, die hierboven al ter sprake is gekomen. ${ }^{150}$ Deze wet, die lijkt op de Franse Code du patrimoine, heeft zes wetten op het

147 'Op een prent van Reinier Vinkeles wordt het kanon met vier andere historische voorwerpen door de Franse generaal J.B. Dumonceau en zijn mannen het gebouw van de Staten-Generaal binnengedragen. Toen de Franse troepen begin 1795 de macht grepen, vluchtte de stadhouder, prins Willem V, naar Engeland en namen de Fransen zijn achtergebleven bezittingen in beslag. Vijf 'vaderlandsche gedenkstukken' waaronder het kanon werden plechtig overhandigd aan de nieuwe volksvertegenwoordiging, die ze een ereplaats in het gebouw van de Staten-Generaal aan het Binnenhof in Den Haag gaf.' Het nieuwe Nederland had geen stadhouders nodig. Het kanon van de koning van Kandy, Rijksmuseumobject, Historiek.net, 30 november 2019.

148 Trouw, 12 maart 2019. Zie ook: De Groene Amsterdammer, 25 maart 2020, 'Een westerse worsteling met goede bedoelingen', door Niels Matthijssen; NRC, 16 oktober 2020: 'Teruggave van roofkunst is niet slechts een ethische kwestie', door Evelien Campfens.

149 Onder de titel 'Koloniale collecties en erkenning van onrecht', 7 oktober 2020. Raadpleegbaar op: www.rijks overheid.nl.

150 T. Barkhuysen en M. Claessens, Naar een zorgvuldige omgang met particulier en openbaar kunstbezit via de nieuwe Erfgoedwet?, in: Nederlands Juristenblad, afl. 39, 2015, 2730-2738; Verslag van Vereniging Kunst Cultuur en Recht (VKCR)-bijeenkomst 'De Erfgoedwet' op 18 november 2016. www.vkcr.nl; A. Salomons en I. van der Vlies, Recht inzake cultuurgoederen, in: Kunst, recht en beleid, 123-189. Door het wegvallen van de Europese binnengrenzen in 1993 waren de lidstaten bang voor het verlies van het nationale cultuurbezit. Er kwam regelgeving tot stand die het nationale cultuurgoed moest beschermen zowel aan de binnengrenzen als aan de buitengrenzen van de EU. Het zijn Richtlijn 2014/60/EU en Verordening (EG) nr 116/2009. De werking geldt voor Nederland alleen wanneer cultuurgoederen na 1 januari 1993 onrechtmatig buiten het grondgebied van een lidstaat zijn gebracht. De op grond van de Erfgoedwet beschermde goederen vallen onder de Richtlijn. Richtlijn 2014/60/EU is in de Erfgoedwet opgenomen in artikel 8.8. En eveneens geïmplementeerd in de artikelen 3:86 a lid 1 en 3: 310 a BW. Zie hieronder noot 185 en 200. 


\section{EEN TREURENDE MONNIK EN EEN ADELAAR}

gebied van cultureel erfgoed vervangen. ${ }^{151}$ Behalve particulier kunstbezit valt ook openbaar kunstbezit onder deze wet. Openbaar kunstbezit is de kunst die eigendom is van overheden en vaak in musea hangt. ${ }^{152}$ Met het inwerkingtreden van de Erfgoedwet is er nu voor het eerst een wet die het openbaar kunstbezit beschermt. Voordien achtte men dat niet nodig. In de Memorie van Toelichting op de oude Wbc staat nog dat men er in het algemeen op mag vertrouwen 'dat de overheid en de daaronder ressorterende musea voldoende verantwoordelijkheidsbesef hebben om het verdwijnen van eigen werkelijk belangrijk kunstbezit tegen te gaan. ${ }^{153}$ Tegenwoordig dreigen steeds belangrijke stukken uit de overheidscollecties te worden verkocht vanwege begrotingsproblemen. We zullen echter zien dat de Erfgoedwet strenger is voor de particulier dan voor de overheid.

\section{Particulier kunstbezit}

De Erfgoedwet tracht het particulier kunstbezit te beschermen door de kunstvoorwerpen een bijzondere status te geven. De Minister van Cultuur kan goederen 'die van bijzondere cultuurhistorische of wetenschappelijke betekenis of uitzonderlijke schoonheid zijn en die als onvervangbaar en onmisbaar behoren te worden behouden voor het Nederlands cultuurbezit' 'aanwijzen'. Men vergelijke de aanwijzing door de minister tot Rijksmonument. ${ }^{154}$ Het goed is volgens de wet onvervangbaar 'indien er geen of nagenoeg geen ander of gelijksoortig cultuurgoed in goede staat in Nederland aanwezig is' en het is onmisbaar 'indien het een symboolfunctie, schakelfunctie of ijkfunctie heeft'. ${ }^{155}$ De Minister kan ambtshalve een cultuurgoed aanwijzen. ${ }^{156}$ 'Ambtshalve' wil zeggen dat 'derden (zoals organisaties die zich beijveren voor bescherming van cultuurbezit) geen formele aanvraag tot aanwijzing van een cultuurgoed bij de Minister kunnen indienen, althans dat de Minister op zo'n aanvraag niet formeel hoeft te besluiten'. ${ }^{157}$ Ambtshalve aanwijzing voorkomt aanvragen en daaruit volgende procedures. ${ }^{158}$ De aanwijzing is een beschikking in de zin van de Algemene Wet Bestuursrecht en kan aan de rechter worden

151 Te weten, de Monumentenwet 1988, de Wet verzelfstandiging rijksmuseale diensten 1993, de Wet tot behoud van cultuurbezit 1985, de Wet tot teruggave cultuurgoederen uit bezet gebied 2007, de Uitvoeringswet UNESCO-verdrag 1970 over onrechtmatige invoer, uitvoer of eigendomsoverdracht van cultuurgoederen, de Regeling materieel beheer museale voorwerpen 2013.

152 Barkhuysen en Claessens, noot 150, 2730.

153 Kamerstukken II, 1980/81, 16749, A-C, 9 (MvT Wbc) Barkhuysen, Claessens, noot 150, 2733. De MvT van de Wbc is te raadplegen op: officielebekendmakingen.n1/kst-34109-3.html

154 Artikel 3.1 v. Erfgoedwet.

155 Artikel 3.7.4 Erfgoedwet. Onder 'symboolfunctie' wordt volgens de Memorie van Toelichting verstaan de functie van een cultuurgoed als duidelijke herinnering aan personen of gebeurtenissen die voor de Nederlandse geschiedenis van overtuigend belang zijn. Met 's chakelfunctie' wordt gedoeld op de functie van een cultuurgoed als wezenlijk element in een ontwikkeling die voor de wetenschapsbeoefening, met inbegrip van de beoefening van de cultuurgeschiedenis, in Nederland van overtuigend belang is. De 'ijkfunctie' ten slotte is de functie van een cultuurgoed als wezenlijke bijdrage in het onderzoek of de kennis van andere belangrijke cultuurgoederen. MvT, Kamerstuk 2014/2015, 34109, 3. Te raadplegen op: officielebekendmakingen.nl/kst-34109-3.html

156 Artikel 3.7 Erfgoedwet. Salomons en Van der Vlies, noot 150, 138-139.

157 'Van terughoudend naar betrokken', noot 6, 32.

158 Barkhuysen, Claessens, noot 150, 2735. 
voorgelegd; er is sprake van marginale toetsing. De Minister kan het besluit tot aanwijzing ook weer intrekken. ${ }^{159}$

In drie gevallen is voor aanwijzing toestemming van de eigenaar vereist. Ten eerste als hij de maker of de erfgenaam van de maker van het object is. In de tweede plaats als hij degene is die het object naar Nederland heeft gebracht of als hij degene is die het vijf jaren nadien heeft verworven. Ten slotte, als hij erfgenaam is van diegenen die zojuist zijn genoemd. ${ }^{160}$ Aanwijzing brengt beperking van het eigendomsrecht mee, hetgeen gerechtvaardigd wordt met het argument dat het belang om het goed in Nederland te houden zwaarder weegt dan het belang van de particulier. Wil een particuliere eigenaar zijn 'aangewezen' cultuur goed vervreemden, dan moet hij dat melden aan de zogeheten erfgoedinspectie. ${ }^{161}$ Hetzelfde geldt als de eigenaar het goed wil verplaatsen, in veiling wil brengen, verhuren, bezwaren, in bruikleen wil geven of het goed bij een boedelscheiding aan een niet-ingezetene wil toedelen. ${ }^{162}$ Bij dreiging van een handeling die ertoe leidt dat het beschermo cultuurgoed naar het buitenland verdwijnt en verloren gaat voor het in Nederland aanwezige cultuurbezit, kan de Minister bedenkingen uiten, die in de Staatscourant worden gepubliceerd. ${ }^{163}$ De rechtshandeling is dan verboden. ${ }^{164}$ Voor verplaatsing naar het buitenland is toestemming van de Minister nodig. ${ }^{165}$ Mogelijke (andere) kopers kunnen zich vervolgens melden bij de Minister. ${ }^{166}$ De Staat hoopt uiteraard dat er een mecenas zal opduiken die het cultuurgoed wil kopen en het goed in Nederland tentoonstelt. De eigenaar is vrij om met de gegadigden in zee te gaan. Komt er zes weken na de publicatie in de Staatscourant geen koopovereenkomst tot stand, dan gelden de bedenkingen als aanbod door de Staat tot aankoop. De Staat gaat vervolgens met de eigenaar in onderhandeling. Vindt de eigenaar de door de Staat aangeboden koopsom te laag, dan kan een van beide partijen de rechtbank Den Haag verzoeken de koopsom vast te stellen; cassatie is mogelijk. ${ }^{167}$ Is de koopsom eenmaal onherroepelijk vastgesteld, dan is het gedurende een maand nog mogelijk dat de eigenaar van de koop afziet of dat de Minister zijn bedenkingen intrekt. ${ }^{168}$ In het laatste geval is de eigenaar 'vrij'. Overtreding van de regeling in de Erfgoedwet door de particuliere eigenaar is een strafbaar feit.

In de inleiding is al gezegd dat de Minister tot nu toe een terughoudend aanwijzingsbeleid

159 Artikel 3.12 Erfgoedwet.

160 Salomons en Van der Vlies, noot 150, 140. Artikel 3.9 Erfgoedwet.

161 Artikel 4.4 Erfgoedwet. Als de Staat, een provincie, een gemeente of een andere publiekrechtelijke rechtspersoon een cultuurgoed of een verzameling wil vervreemden, dan makt de Minister, Gedeputeerde Staten, het college van B en W of het daartoe bevoegde orgaan krachtens artikel 4.17 Erfgoedwet het voornemen bekend. Hetzelfde geldt als het voornemen bestaat dat aan een andere partij dan genoemde (overheids) organen wordt vervreemd.

162 Artikel 4.4 Erfgoedwet.

163 Artikelen 4.6 en 4.9 Erfgoedwet.

164 Artikel 4.6 lid 1 Erfgoedwet.

165 Artikel 4.5.2 Erfgoedwet.

166 Artikel 4.10 Erfgoedwet.

167 Artikel 4.14 Erfgoedwet.

168 Artikel 4.15 erfgoedwet. 


\section{EEN TREURENDE MONNIK EN EEN ADELAAR}

voerde. De reden voor de terughoudendheid is een financiële; de Staat kan niet altijd een passend bod doen om het goed te kopen. Het gaat veelal om miljoenen, zoals in het recente geval van Rembrandts 'Marten en Oopjen'. Een ander sprekend voorbeeld is Mondriaans schilderij 'Victory Boogie Woogie', dat de Staat in 1998 voor tachtig miljoen gulden aanschafte. Toenmalig Staatssecretaris van Cultuur Rick van der Ploeg wimpelde de kritiek op de koop af met de woorden van Oscar Wilde: 'Nowadays people know the price of everything and the value of nothing'. ${ }^{169}$ Een andere reden voor het terughoudende beleid van vandaag de dag is dat Nederland al een goede kerncollectie heeft en de noodzaak tot aanwijzing ontbreekt. ${ }^{170}$ Alleen als een object "op het punt staat" voorgoed naar het buitenland te worden uitgevoerd', zoals in de Franse casus het geval was, maakt de Minister van de bevoegdheid tot aanwijzen gebruik. De Minister moet dus uiteraard wel op de hoogte zijn van het bestaan van zo'n goed. Als de eigenaar niets meldt en het goed eenmaal naar het buitenland heeft verkocht is het te laat; de Minister kan dan niet meer 'aanwijzen'.

De praktijk leert dat er 'noch via de aanwijzingsregeling noch anderszins waarborgen bestaan dat de Minister überhaupt bekend kan zijn met de aanwezigheid van mogelijk belangwekkende cultuurgoederen en verzamelingen in particulier bezit'. ${ }^{171}$ Vandaar dat de commissie Pechtold de Minister dan ook adviseerde actiever te zijn in het opsporen van kunst bij particulieren en vervolgens een fanatieker aanwijzingsbeleid te voeren. Ik denk echter dat de Franse oplossing in dezen effectiever is. De Franse eigenaar die een belangrijk cultuurgoed wil verkopen en voor het hoogste bod veelal de buitenlandse markt op wil, moet de Minister om een uitvoercertificaat vragen. De Minister kan het goed dan alsnog aanwijzen.

Hetzelfde probleem speelt hier te lande overigens bij een schat die bij toeval gevonden wordt. De vinder moet weliswaar aangifte doen (artikel 5:13 lid 3 jo 5: 5 BW) en de Minister kan de vondst dan aanwijzen, maar als de vinder geen aangifte doet wordt hij ook eigenaar. De Minister zal dus niet per definitie weten van de vondst van een bijzondere schat. Jansen pleit voor invoering van het Engelse stelsel. ${ }^{172}$ De vinder in Engeland is op straffe van een gevangenisstraf en/of een boete verplicht de Staat van de vondst in te lichten en aan de Staat af te geven. Als de Staat na onderzoek besluit geen aanspraak te willen maken, dan wordt de Staat geacht geen eigenaar te zijn geworden. Wil de Staat de schat houden, dan moet hij de marktwaarde betalen aan de belanghebbende(n) bij de vondst. Frankrijk kent een soortgelijke regel. Volgens de Code $d u$ patrimoine 'worden roerende archeologische goederen verondersteld eigendom te zijn van de Staat zodra ze tijdens een archeologische expeditie worden blootgelegd en, in geval van een toevallige vondst, als hun wetenschappelijk belang is erkend zodat het behoud door de Staat is gerechtvaardigd'. ${ }^{173}$

169 In: The picture of Dorian Gray, hoofdstuk 4. Trouw, 1 september 1998.

170 'Van terughoudend naar betrokken', noot 6, 8.

171 'Van terughoudend naar betrokken', noot 6, 47.

172 J.E. Jansen, Schatvinding en de bescherming van cultureel erfgoed in Nederland en Engeland, in: Nederlands Juristenblad, mei 2020, afl. 20, 1463-1468, 1464, 1466 v.

173 Artikel L 541-4 van de Code du patrimoine bepaalt dat de artikelen 552 en 716 Code civil met betrekking tot de rechten van de grondeigenaar en van de schatvinding niet van toepassing zijn op roerende archeologische goederen die zijn blootgelegd na een archeologische opgraving of na een toevallige 


\section{VAN DER VEN, F.A.J.}

De commissie Pechtold geeft overigens wel toe dat aanwijzing tot een beschermd kunstwerk leidt tot inbreuk op het eigendomsrecht. Zij adviseerde daarom dat deze inbreuk zoveel mogelijk moet worden verzacht, meer dan momenteel het geval is. De overheid moet met particulieren 'afspraken op maat' maken en hen tegemoet komen door bijvoorbeeld een overheidsbijdrage te verstrekken voor de beveiliging en voor de verzekering van het cultuurgoed of door een gunstige toepassing van de fiscale kwijtscheldingsregeling op grond van de Successiewet. De overheid moet in deze ruimhartiger zijn als de eigenaar belooft 'dat hij het aangewezen culturgoed voor publiek in Nederland toegankelijk maakt of houdt, zoals door bruikleen aan een museum.' ${ }^{174}$ Voor wat, hoort wat.

\section{Openbaar kunstbezit}

Voor 'openbaar kunstbezit', de goederen in eigendom van overheden, geldt een ander regime. De bescherming van het 'openbaar kunstbezit', mag dan haar primeur hebben in de Erfgoedwet, deze bescherming valt in het niet bij de bescherming die de Code du patrimoine het 'openbaar kunstbezit' in Frankrijk biedt.

Zo is het onduidelijk of de Minister een goed uit het 'openbaar kunstbezit' kan aanwijzen. Het is echter niet waarschijnlijk 'omdat de bevoegdheid tot aanwijzing in beginsel ziet op particulier kunstbezit'. ${ }^{175}$ Het regime komt er in het kort op neer dat als de Staat, een provincie, een gemeente of een andere publiekrechtelijke rechtspersoon een cultuurgoed wil vervreemden, de betreffende bestuursorganen advies kunnen vragen aan een commissie van deskundigen die moet beoordelen of het goed onvervangbaar en onmisbaar is voor het

vondst in de grond waarvan de eigendom werd verworven na de datum van inwerkingtreding van de wet $\mathrm{n}^{\circ}$ 2016-925 van 7 juli 2016 'relative à la liberté de la création, à l'architecture et au patrimoine'. Les articles 552 et 716 du code civil ne sont pas applicables aux biens archéologiques mobiliers mis au jour à la suite d'opérations de fouilles archéologiques ou de découvertes fortuites réalisées sur des terrains dont la propriété a été acquise après la date d'entrée en vigueur de la loi $n^{\circ} 2016-925$ du 7 juillet 2016 relative à la liberté de la création, à l'architecture et au patrimoine. Ces biens archéologiques mobiliers sont présumés appartenir à l'Etat dès leur mise au jour au cours d'une opération archéologique et, en cas de découverte fortuite, à compter de la reconnaissance de l'intérêt scientifique justifiant leur conservation.

174 'Van terughoudend naar betrokken', rapport commissie Pechtold, noot 6, 66-67.

175 Barkhuysen, Claessens, noot 150, 2736, 2737, noot 39. De minister kan - in theorie - overgaan tot aanwijzing. De aanwijzing van deze goederen wordt, enerzijds, wel als optie genoemd in Kamerstukken II 2014/2015, 34109, 7, 47. In Kamerstukken I2015/2016, 34109, C, 3 wordt, anderzijds, weer expliciet naar 'particulier bezit' verwezen. De Kamerstukken zijn te raadplegen op resp. officielebekendmakingen.n1/kst-34109-43.html en officielebekendmakingen.n1/kst-34109-I.html. De Commissie Pechtold vraagt om 'verduidelijking over de vraag of de aanwijzingsregeling alleen voor 'particulier bezit' geldt of ook voor 'publiek bezit'. 'Er bestaat een disbalans in de bescherming van cultuurgoederen in particulier versus publiek bezit. (...) De mogelijkheid tot uitvoer van het beschermde cultuurgoed in particulier bezit buiten Nederland wordt met een aanwijzing bijvoorbeeld bij voorbaat sterk beperkt, waar dat voor de publieke regeling niet geldt. Dit terwijl een inbreuk op het eigendoms recht voor particulieren zwaarder weegt dan voor bijvoorbeeld de Staat.' 'Van terughoudend naar betrokken', rapport commissie Pechtold, noot 6, 10, 14, 45. 


\section{EEN TREURENDE MONNIK EN EEN ADELAAR}

Nederlandse cultuurbezit. ${ }^{176}$ Het vragen van dit advies is niet verplicht, tenzij redelijkerwijs kan worden vermoed dat het goed aan de genoemde criteria voldoet én de betreffende overheidsorganen voornemens zijn te vervreemden aan een andere partij dan de Staat, een provincie, een gemeente, of een andere publiekrechtelijke rechtspersoon. Het overheidsorgaan heeft het heft in handen. Zo beoordeelt het zelf of vermoed wordt dat het goed aan de criteria voldoet. En besluit het overheidsorgaan dat er advies moet worden gevraagd, dan bepaalt hetzelfde orgaan wie de commissieleden zijn. Het advies is vervolgens niet bindend. Bepaalt de commissie dat het goed onvervangbaar en onmisbaar is en het overheidsorgaan besluit desondanks tot vervreemding over te gaan, dan kan de minister nog een vernietigingsbesluit uitvaardigen. De meeste discussie zal gaan over cultuurgoed dat, 'enerzijds niet tot de 'top drie' behoort (waarvan het kraakhelder is dat deze kunst beschermwaardig is), maar anderzijds wel nog een flink bedrag kan opleveren'. ${ }^{177}$ Tegen een besluit dat het goed onttrokken mag worden aan het openbaar bezit staat geen beroep bij de bestuursrechter open. ${ }^{178}$ Vooral het mecenaat, dat zich eeuwenlang heeft ingezet voor de totstandkoming van een Nederlandse kunstcollectie, is hierover niet te spreken. ${ }^{179}$

\section{De oplossing van de twee Franse casus naar Nederlands recht}

\section{Inleiding}

Een revolutie zoals in Frankrijk hebben wij niet gehad, maar na de Hervorming, waarbij er een scherpe scheiding tussen kerk en Staat teweeg werd gebracht, zijn de geestelijke goederen 'in het grootste deel onzer provinciën tot Staatsgoed verklaard' ${ }^{180}$, dat wil zeggen geconfisqueerd. In Groningen werden volgens het 'Tractaat der Reductie' in 1594 alle kloostergoederen provinciaal domein. De goederen en inkomsten daaruit moesten worden aangewend voor 'vrome doeleinden', ad pios usus, waartoe onder andere de educatie van de jeugd werd gerekend. De stichting van de Groningse Universiteit werd uit de opbrengst

176 Artikel 4.17 v. Hetzelfde criterium dus dat geldt voor de aanwijzing van cultuurgoed in privé-eigendom. Besluiten zij geen advies te vragen, dan kan een ieder volgens artikel 4.17 .3 binnen zes weken zijn mening te kennen geven dat het wel een goed betreft dat onmisbaar is voor het Nederlandse cultuurbezit. De overheidsorganen bes lissen vervolgens zelf of zij alsnog advies vragen. Voor een museum dat werken wil afstoten bestaat de zogeheten 'Leidraad Afstoten Museale Objecten' 2016 (LAMO), een leidraad om de afstotingsprocedure goed te laten verlopen. Zo is een aantal voorwaarden opgesteld waaronder museumstukken kunnen worden verkocht. Het is slechts een handvat en heeft dus geen wettelijke status. Te raadplegen op: www.mus eumvereniging.nl.

177 Barkhuysen, Claessens, noot 150, 2737.

178 In tegenstelling tot een besluit tot bijvoorbeeld de sloop van een monument. Daarover kan in verband met het vergunningenstelsel wel bij de bestuursrechter worden geprocedeerd. Barkhuysen, Claessens, noot 150, 2737.

179 Barkhuysen, Claessens, noot 150, 2737.

180 J.R. Thorbecke, Aanteekening op de Grondwet, deel II, Amsterdam 1843, blz. 223. Zie ook: W.A. van Verschuer, W. Heineken, de Rechtstoestand der kerkelijke goederen bij de Hervormden, in: De Gids, jaargang 37, Amsterdam 1873, 463-501, 471, noot 1. 


\section{VAN DER VEN, F.A.J.}

van de kerkelijke goederen bekostigd. ${ }^{181}$ Nieuwe gebouwen waren niet nodig; een kloosterkerk en stichtshuizen waren overal wel te vinden. De kasten van de Academiebibliotheek waren gevuld met uit kloosters geroofde boeken. ${ }^{182}$

Het is niet moeilijk voor te stellen dat er tijdens en na de Hervorming allerlei goederen uit kerken en kloosters zijn verdwenen en in particuliere handen terecht zijn gekomen; daarbij kon het gaan om kunstobjecten die nu voor Nederland van groot nationaal belang zijn, zoals 'Pleurant No 17' en het 'fragment met de adelaar' dat zijn voor Frankrijk.

Bij de oplossing van de casus gebruik ik gemakshalve dezelfde namen als in de Franse casus. We zullen zien dat het verschil in bescherming tussen 'aangewezen' en 'niet aangewezen' cultuurgoederen zich in ons burgerlijk recht onder andere uit bij de verkrijgende verjaring en de derdenbescherming.

\section{Derdenbescherming ex artikel 3: $86 \mathrm{BW}$}

\section{Inleiding}

In tegenstelling tot de Franse Code civil, kent ons Burgerlijk Wetboek voor krachtens de Erfgoedwet aangewezen kunstwerken en openbaar kunstbezit specifieke verjaringsregels. $\mathrm{Bij}$ de derdenbescherming is een uitzondering gemaakt voor deze cultuurgoederen. ${ }^{183} \mathrm{Zo}$ bepaalt artikel 3: 86 a lid 2 het volgende:

\footnotetext{
'Artikel 3: 86 kan evenmin worden tegengeworpen aan degene die als eigenaar een roerende zaak opeist, die op het tijdstip waarop hij het bezit daarvan verloor, krachtens de Erfgoedwet als beschermd cultuurgoed was aangewezen of waarvan het buiten Nederland brengen op grond van artikel 4.22 van die wet verboden is. Degene die toen in het register (van beschermd cultuurgoed) of op een inventarislijst, bedoeld in artikel 4.22, tweede lid, van die wet, als eigenaar werd vermeld, wordt vermoed toen eigenaar van de zaak geweest te zijn.'
}

Een beroep op derdenbescherming door de bezitter tegen de eigenaar gaat volgens het tweede lid van artikel 3: 86 a BW dus niet op als het gaat om een cultuurgoed dat is 'aangewezen' en derhalve een beschermde status heeft op het tijdstip dat de eigenaar het bezit verloor.

Artikel 4.22 Erfgoedwet gaat over goederen die behoren tot het openbaar kunstbezit. ${ }^{184}$ Dus ook als het een 'openbaar' cultuurgoed is waarvan de Staat, de provincie of een andere

181 J. Huizinga, Academia Groningana MDCXIV-MCMXIV, Groningen 1914, Eerste gedeelte, Tweede Hoofdstuk, De academische gebouwen tot omstreeks 1830, 24; W.B.S. Jonckbloet, Geschiedenis der Hoogeschool te Groningen, Groningen 1864, 27 v.; J.H.A. Lokin, De Groninger faculteit der Rechtsgeleerdheid (1596-1970), Den Haag 2019, 38 en 44.

182 Lokin, noot 181, 44.

183 W.H.M. Reehuis, A.H.T. Heisterkamp, Goederenrecht, Deventer 2019, 138.

184 Artikel 4.22 Erfgoedwet: Het is verboden een cultuurgoed dat deel uitmaakt van een openbare collectie die is vermeld in de inventarislijst van een museum, een archief of een vaste collectie van een bibliotheek, en waarvan de Staat of een ander openbaar lichaam eigenaar is, buiten Nederland te brengen zonder dat de eigenaar daarvoor schriftelijk toestemming heeft gegeven. 


\section{EEN TREURENDE MONNIK EN EEN ADELAAR}

publiekrechtelijke rechtspersoon eigenaar is en het goed op een inventarislijst staat, gaat een beroep op artikel 3:86 BW niet op. De derde te goeder trouw die verkregen heeft van een beschikkingsonbevoegde geniet dus geen bescherming van artikel 3: $86 \mathrm{BW}$ en moet het goed aan de eigenaar teruggeven. ${ }^{185}$

Artikel 3: 86 a BW bepaalt in het derde lid dat de rechter die een vordering van de eigenaar toewijst, aan de bezitter een naar gelang van de omstandigheden vast te stellen billijke vergoeding kan toewijzen, indien de bezitter bij de verkrijging van de zaak de nodige zorgvuldigheid heeft betracht. ${ }^{186}$ Of de bezitter zorgvuldig heeft gehandeld hangt volgens artikel 3:87 a BW af van de omstandigheden van de verwerving, zoals de hoedanigheid van partijen, de betaalde prijs en of de bezitter een herkomstonderzoek heeft verricht. ${ }^{187}$ In feite betekent 'zorgvuldigheid' in dezen dat hij te goeder trouw was in de zin van artikel 3:11 BW. De vergoeding strekt niet noodzakelijk tot een volledige schadevergoeding. De omstandigheden kunnen ertoe leiden dat de rechter een beperkte schadevergoeding toekent. De rechter kan bijvoorbeeld het aankoopbedrag en eventuele restauratiekosten toekennen in plaats van een hogere actuele verkoopwaarde. ${ }^{188}$

Op antiekhandelaren zoals Brimo rusten zware verplichtingen: behalve dat zij de toepasselijke registers moeten raadplegen en zich tot de toegankelijke instanties moeten wenden, moeten zij zich ook vergewissen van de identiteit van de verkoper en hem een schriftelijke verklaring vragen waarin staat dat de verkoper bevoegd was over de zaak te beschikken. De gegevens die zij van de verkoper krijgen, moeten zij vervolgens in een door

185 Volgens artikel 3: 86 a lid 2 kan artikel 86 evenmin worden tegengeworpen aan een lidstaat van de Europese Unie of aan een andere Staat die partij is bij de Overeenkomst betreffende de Europese Economische Ruimte die een roerende zaak opeist, die krachtens de nationale wetgeving van die Staat een cultuurgoed is in de zin van artikel 2, onder 1, van Richtlijn 2014/60/EU (..) van 15 mei 2014 betreffende de teruggave van cultuurgoederen die op onrechtmatige wijze buiten het grondgebied van een lidstaat zijn gebracht en houdende wijziging van Verordening (EU) nr. 1024/2012 (PbEU 2014, L 159), mits die zaak in de zin van die richtlijn op onrechtmatige wijze buiten het grondgebied van die Staat is gebracht.

186 Tenzij opeising zonder vergoeding bij toepasselijkheid van artikel 86 lid 3 mogelijk zou zijn geweest. Lid 3 gaat over gestolen goederen. De bezitter te goeder trouw wordt niet meteen eigenaar: de eigenaar van een roerende zaak, die het bezit daarvan door diefstal heeft verloren, kan deze gedurende drie jaren, te rekenen van de dag van de diefstal af, als zijn eigendom opeisen.

187 Zie hierover Salomons en Van der Vlies, noot 150, 134. Artikel 3: 87 a BW:1. Om vast te stellen of de bezitter bij de verkrijging van een cultuurgoed als bedoeld in artikel 86 a lid 1 of in artikel 6.1, onder c, van de Erfgoedwet de nodige zorgvuldigheid heeft betracht, wordt rekening gehouden met alle omstandigheden van de verwerving, in het bijzonder a. de documentatie over de herkomst van het goed;

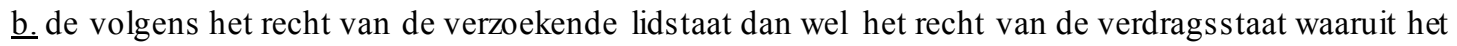
goed afkomstig is, vereiste vergunningen om het goed buiten het grondgebied van die lidstaat of die

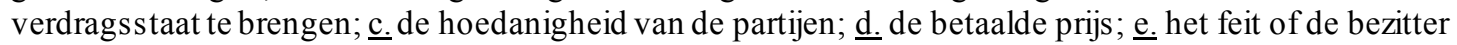
elk redelijkerwijs toegankelijk register met betrekking tot gestolen cultuurgoederen en elke andere relevante informatie en documentatie die hij redelijkerwijs zou kunnen hebben verkregen, heeft geraadpleegd, en het feit of de bezitter toegankelijke instanties heeft geraadpleegd; $\underline{f}$. het feit of de bezitter alle andere stappen heeft genomen die een redelijk handelende persoon in die omstandigheden zou hebben genomen.

188 Burgerlijk Wetboek, Tekst en Commentaar, H. B. Krans e.a., Deventer 2019, artikel 3: 87 a lid 1 BW. 
VAN DER VEN, F.A.J.

hen bij te houden register opnemen. ${ }^{189}$ Voor een veilinghouder gelden dezelfde verplichtingen. ${ }^{190}$

\section{'Fragment met de adelaar'}

Gesteld dat een casus als het 'fragment met de adelaar' zich hier zou voordoen, dan geldt het volgende. Brimo, de derde verkrijger, zou geen beroep op derdenbescherming ex artikel 3: 86 lid $1 \mathrm{BW}$ kunnen doen als het fragment was aangewezen op het moment waarop de Staat het bezit verloor, of als het fragment op de inventarislijst 'openbaar kunstbezit' stond vermeld. Het moge duidelijk zijn dat er op het moment van bezitsverlies door de Staat van 'aanwijzing' in de zin van de Erfgoedwet geen sprake kon zijn. Getuige het deskundigenonderzoek was het fragment of in 1836 gestolen of na opgravingen in 1848 verdwenen. Hoe dan ook zou Brimo dus een beroep op derdenbescherming ex artikel 3:86 BW kunnen doen, mits hij op het moment van de bezitsverkrijging te goeder trouw was. Of Brimo te goeder trouw was, is de vraag. Brimo de Laroussilhe was een vooraanstaande antiquair. Had hij onder de gegeven omstandigheden niet moeten twijfelen aan de beschikkingsbevoegdheid van de vervreemder? We beschikken helaas niet over voldoende feiten. De Franse rechter kwam aan de vraag naar de goede trouw niet toe omdat hij de derdenbescherming ex artikel $2276 \mathrm{Cc}$ sowieso niet van toepassing achtte. Het Cour de Cassation was evenwel bereid een vergoeding toe te kennen. Bij de beoordeling van het beroep van Brimo op artikel 1 van het Eerste Protocol van het EVRM oordeelde deze rechter immers dat de veroordeling het goed terug te geven zonder vergoeding - a priori onevenredig zou zijn. Dat een vergoeding werd toegewezen duidt erop dat hij te goeder trouw was.

Het zij opgemerkt dat in een casus als deze, waarin een kunstschat opeens opduikt, en waarvan de eigenaar het bezit al lang geleden heeft verloren, een derde te goeder trouw, die van een beschikkingsonbevoegde heeft verkregen, zich dus vaak met succes zal kunnen beroepen op derdenbescherming. En wel om de eenvoudige reden dat het goed nog niet aangewezen is op het moment waarop de eigenaar het bezit verloor. De eigenaar kan het

189 Artikel 3:87 a lid 2: Een handelaar als bedoeld in artikel 437 van het Wetboek van Strafrecht heeft niet de volgens artikel $86 \mathrm{~b}$ lid 2 bij de verkrijging van een cultuurgoed nodige zorgvuldigheid betracht,

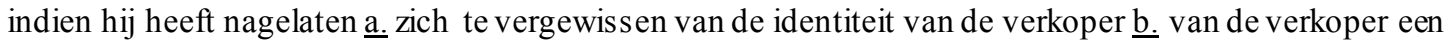
schriftelijke verklaring te verlangen dat hij bevoegd is overde zaak te beschikken; $\underline{c}$. in het door hem bij te houden register de oorsprong van het cultuurgoed, de namen en het adres van de verkoper, de aan de verkoper betaalde koopprijs en een beschrijving van het cultuurgoed op te nemen; $\underline{\mathrm{d}}$. de registers met betrekking tot gestolen cultuurgoederen te raadplegen die in de gegeven omstandigheden in verband met de aard van de cultuurgoederen voor raadpleging in aanmerking komen. Salomons en van der Vlies, noot $150,135$.

190 Artikel 3:87 a lid 3: Een veilinghouder die bij het aannemen van een cultuurgoed ter openbare verkoop niet aan de in de leden 1 en 2 bedoelde zorgvuldigheids eisen voldoet dan wel dit cultuurgoed aan degene die het ter openbare verkoop aanbood, teruggeeft zonder aan deze zorgvuldigheidseisen te hebben voldaan, handelt onrechtmatig jegens degenen die een vordering tot teruggave als bedoeld in artikel 86b kunnen instellen. Salomons en van der Vlies, noot 150, 135. 


\section{EEN TREURENDE MONNIK EN EEN ADELAAR}

verweer ex artikel 3: 86 a BW immers alleen dan tegen de bezitter opwerpen als het goed op het moment van het bezitsverlies was aangewezen.

\section{Pleurant No 17}

Voor de zussen geldt in dezen het volgende. Gesteld dat hun overgrootvader in 1813 verkregen had van een beschikkingsonbevoegde, hadden zij zich dan op derdenbescherming van hun overgrootvader kunnen beroepen en zouden zij vervolgens eigenaar zijn geworden door erfopvolging? Artikel 2014 van het BW van 1838 was toen nog niet van kracht. In 1813 waren wij ingelijfd bij het Franse keizerrijk. Derhalve gold hier te lande de Code civil. Het voorgaande nu zou voor de zussen betekenen dat hun overgrootvader niet door derdenbescherming ex artikel $2276 \mathrm{Cc}$ eigenaar kon zijn geworden. Immers hierboven is gezegd dat artikel $2226 \mathrm{Cc}$ bepaalde dat verkrijgende verjaring van publieke domeingoederen niet mogelijk was. En aangezien de Fransen de verkrijging ex artikel 2276 beschouwen als verkrijgende verjaring zou het feest niet doorgaan.

\section{Verkrijgende verjaring ex artikel 3: 99 BW.}

\section{Inleiding}

Hoe zit het met een beroep op het verjaringsartikel 3:99 BW? Artikel 3: 99 BW bepaalt in lid 1 dat 'rechten op roerende zaken die niet-registergoederen zijn, door een bezitter te goeder trouw worden verkregen door een onafgebroken bezit van drie jaren'. ${ }^{191}$ Volgens lid 2 van dat artikel geldt deze regel echter niet voor 'roerende zaken die krachtens de Erfgoedwet als beschermd cultuurgoed zijn aangewezen of deel uitmaken van de openbare collectie, mits het bezit na die aanwijzing of gedurende dit deel uitmaken is begonnen'. Artikel 3: 99 BW maakt in lid 2 voor aangewezen cultuurgoederen ongeveer dezelfde uitzondering als artikel 3: 86 a lid 2 BW. ${ }^{192}$

\section{'Fragment met de adelaar'}

Was het fragment aangewezen, dan zou een beroep op artikel 3: 99 lid 1 BW niet opgaan als Brimo het bezit van het fragment had verkregen na de aanwijzing of nadat het deel was gaan uitmaken van de openbare collectie en op de lijst stond. Van 'aanwijzing' of plaatsing op de lijst kon nog geen sprake zijn toen Brimo in 2002 het bezit verkreeg. Immers, pas in 2003 raakte de Staat van het bestaan van het fragment op de hoogte.

Ervan uitgaande dat het fragment niet was aangewezen of op de lijst van 'openbaar kunstbezit' stond, en het dus een 'gewoon' cultuurgoed was, dan zou een beroep op verkrijgende verjaring ex artikel 3: $99 \mathrm{BW}$ lid 1 mogelijk zijn als Brimo te goeder trouw was en hij het fragment drie jaar in zijn bezit had gehad. Als we aannemen dat hij te goeder trouw was, dan levert de drie jaar een probleem op. De verjaring begint volgens artikel 3:

191 Het oud BW kende geen verjaring voor roerende goederen.

192 Reehuis, Heisterkamp, noot 183, 286. 


\section{VAN DER VEN, F.A.J.}

101 BW te lopen met de aanvang van de dag na het begin van het bezit. Brimo werd in 2002 bezitter en een jaar later stelde de Staat de revindicatie al in. Wellicht dat de accessio possessionis-regel ex artikel 3: 102 lid 2 BW uitkomst kon bieden. Krachtens deze regel zou hij de bezitstijd van zijn voorganger die al met de verjaring was begonnen bij die van hemzelf kunnen optellen en wel aan de vereiste drie jaar kunnen voldoen. Het zou zelfs zo kunnen zijn dat in de keten van zijn voorgangers de verkrijgende verjaring al had plaatsgehad en hij van een beschikkingsbevoegde de eigendom door levering had verkregen. Was hij te kwader trouw dan zou, zoals we straks zullen zien, een beroep op bevrijdende verjaring ex artikel 3:105 BW nog mogelijk zijn.

\section{Pleurant No 17}

De verkrijgende verjaring ex artikel 3: 99 BW speelt eveneens een rol in de casus van de Pleurant. Voor de drie zussen geldt dat als het beeld was aangewezen voordat zij het bezit van het beeld hadden gekregen, zij geen beroep op artikel 3: 99 BW konden doen. In hun geval was 'aanwijzing' mogelijk geweest omdat de Staat sinds 1914 van het bestaan van Pleurant No 17 op de hoogte was of in ieder geval kon zijn. Was Pleurant No 17 aangewezen, dan zou, zoals nog zal blijken, een beroep op bevrijdende verjaring ex artikel 3: 105 BW uitkomst bieden.

Was het beeld daarentegen niet aangewezen, dan zou een beroep op 3: 99 BW kunnen slagen, mits de zussen te goeder trouw waren en ze het beeld drie jaar in hun bezit hadden. We weten niet precies wanneer zij het beeld hebben geërfd en of zij te goeder trouw waren. Bij de goede trouw van hun overgrootvader die het beeld in 1813 kocht konden, zoals gezegd, vraagtekens worden gesteld. Stel dat hij inderdaad te kwader trouw was geweest toen hij het bezit verkreeg, dan waren zijn opeenvolgende opvolgers onder algemene titel ook te kwader trouw. Goede en kwade trouw vererven immers. ${ }^{193}$ De zussen hadden in dat geval dan ook niet een beroep kunnen doen op artikel 3:99 BW. We zullen straks zien dat de bevrijdende verjaring van artikel 3:105 BW hen ook dan uitkomst zou kunnen bieden.

Als we aannemen dat hun overgrootvader wel te goeder trouw was en de zussen dus ook, dan was een beroep op artikel 3: 99 BW mogelijk als zij drie jaar het bezit hadden gehad. Zouden zii niet aan de termijn hebben voldaan, dan zou hier de accessio possessionis-regel ex artikel 3: 102 lid 1 BW uitkomst kunnen bieden en een beroep op 3: 99 BW succes hebben.

Verkrijgende verjaring gekoppeld aan de bevrijdende verjaring. Artikel 3: 306 jo 3: 105 BW

'Gewone' cultuurgoederen

193 Artikel 3: 102 lid 1 BW. 


\section{EEN TREURENDE MONNIK EN EEN ADELAAR}

Ook de verjaring van rechtsvorderingen is aan de Erfgoedwet aangepast. De aanpassing geldt, net zoals bij de hierboven besproken artikelen, voor aangewezen goederen en voor goederen uit de openbare collecties die in het register staan.

Gaat het om de 'gewone' cultuurgoederen dan zijn de 'gewone' verjaringsregels van kracht. De revindicatie verjaart in dat geval na twintig jaar (artikel 3:306 BW) en degene die een goed bezit op het tijdstip waarop de verjaring van de rechtsvordering strekkende tot beëindiging van het bezit wordt voltooid, verkrijgt dat goed, ook al was zijn bezit niet te goeder trouw (3:105 lid 1). ${ }^{194}$ De termijn van de verjaring van de revindicatie begint krachtens artikel 3: 314 BW te lopen de dag na het bezitsverlies. ${ }^{195}$

De Hoge Raad heeft in 2012 geoordeeld dat voor de verkriigende verjaring ex artikel 3: 105 BW niet van belang is dat opvolging in het bezit heeft plaatsgevonden en dus ook niet of opvolgende bezitters te goeder trouw waren in de zin van artikel 3:102 BW. ${ }^{196}$ Volgens dit artikel kan de bezitter, zoals gezegd, de bezitstijd van zijn voorganger bij die van hemzelf optellen. ${ }^{197}$

\section{'Fragment met de adelaar'}

Hierboven hebben we geconcludeerd dat Brimo met succes een beroep op de verkrijgende verjaring ex artikel 3: $99 \mathrm{BW}$ zou kunnen doen als het fragment niet was aangewezen, mits hij te goeder trouw was.

Was Brimo te kwader trouw geweest, dan zou hij een beroep kunnen doen op de artikelen 3: 306 jo 3:105 lid $1 \mathrm{BW}$. Misschien zou ergens in de keten van zijn voorgangers de verkrijgende verjaring ex artikel 3: 105 lid $1 \mathrm{BW}$ al hebben plaatsgevonden. In dat geval zou Brimo in 2002 hebben verkregen van een beschikkingsbevoegde en door levering eigenaar zijn geworden. Het is duidelijk dat de revindicatie van de Staat in 2002, toen Brimo bezitter werd, al lang was verjaard. Deze verjaring had zelfs al plaatsgevonden in de tijd dat het oud BW van 1838 nog van kracht was. Onder het Oud BW gold een termijn van dertig jaar voor het verjaren van de revindicatie. ${ }^{198}$ De termijn begon te lopen vanaf het tijdstip dat een ander dan de eigenaar bezitsdaden ten aanzien van de zaak verrichtte. ${ }^{199}$ Het verstrijken van de termijn was dus niet afhankelijk van de vraag of de eigenaar zijn vordering had kunnen instellen, in welk geval de termijn begint te lopen op het tijdstip dat de eigenaar zijn zaak ontdekt; de zogeheten aan het Amerikaanse recht ontleende 'discovery-rule'.

Getuige het deskundigenonderzoek was het fragment, zoals gezegd, of in 1836 gestolen of na opgravingen in 1848 verdwenen. Er waren dus in ieder geval na 1848 gedurende meer dan dertig jaren opeenvolgende bezitters van het fragment geweest. Het rechtsgevolg van het verjaren van de revindicatie was onder het oud BW dat de revindicatie teniet ging en de

194 Zie hierover: Reehuis, Heisterkamp, noot 183, 289; Jansen, noot 51, 253 v.

195 Zie hierover: Jansen, noot 51, 254 en 306.

196 HR 10 augustus 2012, ECLI: BW 5324.

197 Volgens Jansen is het overigens onjuist om de accessio possessionis-regel toe te passen bij de berekening van de verjaringstermijn van de revindicatie. Jansen, noot 51, 73 en 227 e.v.

198 Artikel 2004 BW.

199 HR 8 mei 1998, NJ 1999, 44 (Klooster in een landschap). Zie hierover: Jansen, noot 51, 223 e.v., 230 v. 
eigenaar niet meer met de revindicatie kon ageren. De bezitter was veilig. Het eigendomsrecht bleef echter bestaan; eigendom en bezit bleven gescheiden. In tegenstelling tot de bezitter van roerend goed kwam de bezitter van onroerend goed na die dertig jaar wel voor verkrijgende verjaring in aanmerking, mits hij te goeder trouw was. Bezit te kwader trouw verjaarde onder het oud BW nooit en te nimmer.

Het fragment en zijn toenmalige bezitter waren onder de vigeur van het oude recht dus al veilig geweest voor de revindicatie van de Staat. Toen de Staat de revindicatie in 2003 tegen Brimo instelde was de vordering al verjaard. Maar wanneer verloor de Staat het eigendomsrecht aan de bezitter? Met de invoering van het BW van 1992 kunnen, zoals gezegd, ook bezitters van roerend goed door verkrijgende verjaring eigenaar worden als de revindicatie is verjaard; zelfs als zij te kwader trouw zijn. Degene die een goed bezit op het tijdstip waarop de verjaring van de rechtsvordering strekkende tot beëindiging van het bezit is voltooid, wordt op grond van artikel 3: $105 \mathrm{BW}$ eigenaar. Volgens artikel 73 Overgangsrecht werd artikel 3: 105 BW één jaar na het tijdstip van de inwerkingtreding van toepassing met betrekking tot degene die alsdan een goed bezat indien de rechtsvordering tot beëindiging van dat bezit was voltooid. Het voorgaande betekent dat degene die het fragment in 1993 bezat eigenaar was geworden. Mochten zich tot 2002 geen onregelmatigheden hebben voorgedaan, dan had Brimo van een beschikkingsbevoegde verkregen en was hij door levering eigenaar geworden.

\section{Pleurant No 17}

Hierboven is al gezegd dat artikel 3: 105 BW de zussen ook uitkomst zou bieden als zij en hun voorgangers te kwader trouw waren en de Pleurant niet was aangewezen. De revindicatie was ook onder het oud BW al lang verjaard. Overgrootvader Perret-Carnot kocht het beeld in 1813. Sinds de invoering van het oud BW in 1838 waren er in ieder geval gedurende meer dan dertig jaren opeenvolgende bezitters van het beeld geweest. Ook hier heeft het overgangsrecht met betrekking tot artikel 3: $105 \mathrm{BW}$ tot gevolg dat degene die bezitter was in 1993 de eigendom verkreeg door verkrijgende verjaring. Waarschijnlijk was de vader van de zussen op dat tijdstip de bezitter. Op hun beurt zouden de zussen eigenaar zijn geworden door erfopvolging.

\section{Aangewezen cultuurgoederen; een vreemd rechtsgevolg}

Voor aangewezen cultuurgoederen is de regel van de bevrijdende verjaring aangepast aan de Erfgoedwet. Volgens artikel 3: $310 \underline{b}$ BW verjaart binnen Nederland 'een rechtsvordering tot opeising van een roerende zaak die krachtens de Erfgoedwet als beschermd cultuur goed is aangewezen (...) en die na die aanwijzing (...) uit het bezit van de eigenaar is geraakt, door verloop van vijf jaren na de aanvang van de dag waarop de plaats waar de zaak zich bevindt en de identiteit van de bezitter of de houder zijn bekend geworden, (...)'. Voor 


\section{EEN TREURENDE MONNIK EN EEN ADELAAR}

internationale rechtsvorderingen gelden andere termijnen. ${ }^{200}$ Op hetzelfde ogenblik waarop de revindicatie na vijf jaar is verjaard, wordt de bezitter eigenaar door verkrijgende verjaring ex artikel 3: $105 \mathrm{BW}$, ook al is hij te kwader trouw.

In tegenstelling tot artikel 3: $314 \mathrm{BW}$ dat de aanvang van termijn van de bevrijdende verjaring van de revindicatie met betrekking tot 'gewone' roerende goederen regelt en de termijn de dag na het bezitsverlies laat aanvangen, geldt voor aangewezen cultuurgoederen bij de vijfjarige verjaring de 'discovery-rule'. De eigenaar heeft na de ontdekking waar zijn goed zich bevindt vijf jaar lang de tijd de revindicatie in te stellen.

$\mathrm{Nu}$ is het opmerkelijk dat hetzelfde artikel 3: $310 \underline{b}$ BW voor beschermde cultuurgoederen naast de vijfjarige termijn ook een dertigjarige termijn kent. Het artikel bepaalt namelijk dat de rechtsvorderingen in ieder geval verlopen door 'het verloop van dertig jaren na de aanvang van de dag waarop een niet-rechthebbende bezitter van de zaak is geworden'. De reden waarom deze dertigjarige verjaring is opgenomen is dat geen verjaringstermijn van start zou gaan, en de vordering onverjaarbaar zou zijn als de plaats waar de zaak zich bevindt en de identiteit van de bezitter of de houder niet bekend zijn geworden. Om dit te voorkomen is dus bepaald dat de revindicatie in ieder geval na dertig jaar verjaart. De termijn begint te lopen een dag na het bezitsverlies. Na dertig jaar wordt de bezitter eigenaar door verkrijgende verjaring ex artikel 3: $105 \mathrm{BW}$, ook al is hij te kwader trouw.

Het is dus mogelijk dat de eigenaar de revindicatie pas kan instellen op het tijdstip dat de revindicatie al is verjaard. ${ }^{201}$ In een casus als die van het 'fragment met de adelaar' wordt dit vreemde rechtsgevolg duidelijk. Immers, de Staat had het bezit van het fragment verloren in 1836 of 1848 . De dertigjarige termijn begon na het bezitsverlies te lopen. De Staat kwam in 2003 achter de identiteit van de bezitter. Volgens artikel 3: $310 \underline{b}$ BW had de Staat dus

200 Artikel 3: 310 a en b BW zijn ingevoerd ter implementatie van Richtlijn 2014/60/EU van 15 mei 2014 betreffende de teruggave van cultuurgoederen die op onrechtmatige wijze buiten het grondgebied van een lidstaat zijn gebracht en houdende wijziging van Verordening (EU) nr. 1024/2012. Artikel 3: 310 b geeft een vergelijkbare regeling als artikel 3:310 a, maar dan op nationaal niveau. Artikel 3:310 a BW geldt voor internationale rechtsvorderingen. Lid 1: Een rechtsvordering tot opeising van een roerende zaak die krachtens de nationale wetgeving van een lid-staat van de Europese Unie of van een andere Staat die partij is bij de Overeenkomst betreffende de Europese Economische Ruimte een cultuurgoed is in de zin van artikel 2, onder 1, van de richtlijn, bedoeld in artikel 86a, en waarvan die Staat teruggave vordert op de grond dat zij op onrechtmatige wijze buiten zijn grondgebied is gebracht, verjaart door verloop van drie jaren na de aanvang van de dag, volgende op die waarop de plaats waar de zaak zich bevindt en de identiteit van de bezitter of de houder aan de centrale autoriteit van die Staat als bedoeld in artikel 4 van de richtlijn zijn bekend geworden, en in elk geval door verloop van dertig jaren na de aanvang van de dag volgende op die waarop de zaak buiten het grondgebied van die Staat is gebracht. (NB Richtlijn 2014/60/EU van het Europees Parlement en de Raad van 15 mei 2014 betreffende de teruggave van cultuurgoederen die op onrechtmatige wijze buiten het grondgebied van een lidstaat zijn gebracht en houdende wijziging van Verordening (EU) nr. 1024/2012 (PbEU 2014, L 159)). Lid2: De laatste termijn bedraagt vijfenzeventig jaren in het geval van zaken die deel uitmaken van openbare collecties in de zin van artikel 2, onder 8, van de richtlijn en van kerkelijke goederen als bedoeld in de richtlijn in de lid-staten van de Europese Unie of in de andere staten die partij zijn bij de Overeenkomst betreffende de Europese Economische Ruimte, waar deze zijn onderworpen aan speciale beschermende maatregelen krachtens nationaal recht.

201 Jansen, noot 51, 306. 


\section{VAN DER VEN, F.A.J.}

vanaf 2003 vijf jaar de tijd om te ageren met de revindicatie, maar volgens hetzelfde artikel was de revindicatie toen al verjaard en was op grond van artikel 3:105 BW een voorgaande bezitter door verkrijgende eigenaar geworden; ook als we met het hierboven weergegeven overgangsrecht rekening houden.

De keuze om naast de vijfjarige- ook aan de dertigjarige verjaring vast te houden is ingegeven door de rechtszekerheid. Zou alleen de 'discovery-rule' gelden, dan kan het heel erg lang duren voordat de eigenaar kan ageren. Zolang de eigenaar de identiteit van de bezitter niet heeft ontdekt begint de verjaringstermijn van de revindicatie niet te lopen en blijven eigendom en bezit gescheiden, hetgeen de rechtszekerheid niet ten goede zou komen. Ik vraag mij af waarom het zo erg is dat in dat geval eigendom en bezit gescheiden blijven. De reden dat de 'discovery-rule' en de vijfjarige termijn zijn ingevoerd, is dat eigendomsverlies door verjaring alleen nalatige eigenaren treft. Als deze eigenaren na de ontdekking niet binnen vijf jaar ageren, hebben zij het eigendomsverlies aan zichzelf te wijten. Logisch, maar er zullen ongetwijfeld ook eigenaren zijn die na het bezitsverlies jaren achtereen hun uiterste best doen om achter de identiteit en de vindplaats te komen en daar niet in slagen omdat bijvoorbeeld de dief het goed verborgen houdt. Na dertig jaar is de revindicatie verjaard en is de dief eigenaar geworden omdat de wetgever in dezen de rechtszekerheid boven de rechtvaardigheid heeft gesteld. De rechtszekerheid maakt het dus mogelijk dat de dief eigenaar wordt. ${ }^{202}$ Artikel 3:105 BW werkt in de hand dat het de moeite loont dat dieven hun gestolen waar dertig jaar lang verborgen houden, ook als het om 'aangewezen' cultuurgoed gaat. De Hoge Raad oordeelde in 2017 dat de gedepossedeerde eigenaar tegen de dief uit onrechtmatige daad kan ageren en schadevergoeding kan eisen. ${ }^{203}$ Als de dief de zaak nog onder zich heeft kan de rechter hem veroordelen de eigendom over te dragen. Desondanks blijft het natuurlijk vreemd dat een dief door verjaring eigenaar kan worden.

Deze onrechtvaardigheid is het gevolg van het feit dat de wetgever van het BW van 1992 heeft gebroken met een eeuwenlange traditie en het mogelijk heeft gemaakt dat de bezitter te kwader trouw ook door verjaring eigenaar kan worden. Jansen stelt daarom voor de dertigjarige termijn in de artikelen 3: $310 \mathrm{a}$ en b BW te schrappen. ${ }^{204}$ Volgens Jansen ware het overigens ook logisch om de 'discovery-rule' in te voeren voor de 'gewone' roerende goederen omdat artikel 3: $105 \mathrm{BW}$ goederenrechtelijke rechtsverwerking oplevert. Artikel 3: $314 \mathrm{BW}$, het artikel dat de bevrijdende verjaring van de revindicatie regelt zou daartoe moeten worden aangepast. 'Door de loop van de verjaring afhankelijk te maken van het

202 Zie C.J.H. Brunner, Dief wordt eigenaar, in: Quod-licet: Kleijn-bundel, bundel aangeboden aan W.M Kleijn, Deventer 1992.

203 Over de vordering tot het betalen van schadevergoeding overwoog de Hoge Raad het volgende: 'Voor zover de schade waarvan de benadeelde vergoeding wenst, bestaat in het verlies van zijn eigendom, neemt de vijfjarige verjaringstermijn ingevolge die bepaling een aanvang op het moment dat de benadeelde bekend is met zijn eigendomsverlies (en met de daarvoor aansprakelijke persoon), en is de verjaring in elk geval voltooid twintig jaar na de voltooiing van de verjaring van art. 3:314 lid $2 \mathrm{BW}$, zijnde de gebeurtenis waardoor de schade - het verlies van de eigendom - is veroorzaakt, alles onverminderd eventuele stuiting van die verjaring.' HR 24 februari 2017, ECLI:NL:HR:2017:309. Jansen, noot 51, 223 e.v., 306. 


\section{EEN TREURENDE MONNIK EN EEN ADELAAR}

tijdstip waarop de eigenaar op de hoogte is van de identiteit van de bezitter en de locatie van zijn zaak, is gegarandeerd dat eigendomsverlies alleen nalatige eigenaren treft.' ${ }^{205}$ Een casus als die van Pleurant No 17, waarin de Staat maar liefst honderd jaar niets ondernam nadat hij op de hoogte was van de identiteit van de bezitter, maakt dat duidelijk.

Het voorgaande zou voor de drie zussen betekenen dat, zelfs als de Pleurant tot beschermd cultuurgoed zou zijn gebombardeerd, zij eigenaar waren geworden. Onder het Oud BW was de revindicatie al verjaard, maar was de familie Perret-Carnot nog geen eigenaar geworden. De revindicatie van de verjaring had voor roerend goed immers onder het Oud BW geen eigendomsverkrijging tot gevolg. Eerst in 1993 was de toenmalige bezitter eigenaar geworden op grond van artikel 3:105 BW, ook al was hij te kwader trouw. Vermoedelijk was de vader van de zussen in dat jaar nog bezitter. De zussen verkregen het beeld vervolgens door vererving.

\section{Slotopmerkingen}

Het verschil tussen de bescherming van cultureel erfgoed in Frankrijk en Nederland is groot, zowel wat betreft het 'openbaar kunstbezit' als het particulier 'kunstbezit'. De Franse wetgever heeft met de Code du patrimoine en de Code général de la propriété des personnes publiques wetten gemakt die de eigenaar van cultureel erfgoed weliswaar sterk in zijn beschikkingsbevoegdheid beperken, maar die de eigenaar en zijn erfgoed tegelijkertijd een goede bescherming bieden. De belangrijkste culturgoederen, de trésors nationaux, of ze $\mathrm{nu}$ in eigendom aan de Staat of aan een privépersoon toebehoren, zijn niet vatbaar voor verjaring. Heeft de eigenaar zijn bezit verloren, dan kan hij te allen tijde met de revindicatie zijn goed van de bezitter opeisen. De bezitter kan geen beroep doen op de 'gewone' verjaringsregels van de Code civil en dientengevolge ook niet op derdenbescherming omdat de genoemde wetten hier derogeren aan de Code civil. Met deze oplossing heeft de Franse wetgever duidelijkheid geschapen.

Dat laatste kan niet over de Nederlandse wetgever worden gezegd. We hebben gezien dat de specifieke regels in het Burgerlijk Wetboek voor de krachtens de Erfgoedwet aangewezen cultururgoederen tot vreemde rechtsgevolgen kan leiden. Zo kan het gebeuren dat de eigenaar van een door de overheid aangewezen culturgoed de revindicatie pas kan instellen op het tijdstip dat de revindicatie al is verjaard. Daarbij komt dat artikel 3:105 BW in de hand werkt dat het de moeite loont dat dieven hun gestolen kunstwaar dertig jaar lang verborgen houden, ook als het om 'aangewezen' culturgoed gaat.

Het Nederlandse recht hinkt op twee gedachten. Enerzijds wil de wetgever met de 'aanwijzing' krachtens de Erfgoedwet de eigenaar en zijn cultureel erfgoed een goede bescherming bieden, maar anderzijds wordt die bescherming door de mogelijkheid van de

205 Jansen, noot 51, 223 e.v., 305. 
verjaring ex artikel 3: $105 \mathrm{BW}$ teniet gedaan.

Wat betreft de vervreemding en export van cultureel erfgoed heeft Frankrijk met de Code du patrimoine in tegenstelling tot Nederland een dichtgetimmerd systeem. Behoren de goederen tot het publiek domein, dan is vervreemding en daarmee ook de export naar het buitenland uitges loten. Het zijn res extra commercium. Betreft het privaat eigendom, dan is verkoop naar het buitenland ook niet altijd mogeliik. Ofwel het is een door de overheid geclasseerd goed en daarmee een trésor national, in welk geval export niet is toegestaan. Ofwel, het is een bien culturel, in welk geval de eigenaar voor export een certificaat van de overheid nodig heeft. De eigenaar moet dus 'langs' het overheidsloket. Op deze wijze krijgt de Staat niet alleen zicht op wat particulieren aan cultuurgoed in eigendom hebben, maar heeft de Staat ook de mogelijkheid het goed alsnog te classeren waardoor het tot de trésors nationaux gaat behoren. Daarenboven geeft de Code $d u$ patrimoine de Staat een pressiemiddel om de eigenaar na de weigering van het certificaat te 'overtuigen' tot de verkoop aan de Staat.

Volgens de Nederlandse Erfgoedwet kan de Minister export naar het buitenland voorkomen door goederen in het 'particulier kunstbezit' aan te wijzen waardoor deze een beschermde status krijgen. Het probleem is echter dat er noch via de aanwijzingsregeling noch anderszins waarborgen bestaan dat de Nederlandse overheid bekend kan zijn met de aanwezigheid van mogelijk belangwekkende cultuurgoederen en verzamelingen in particulier bezit. Is een goed niet aangewezen, dan is de eigenaar in tegenstelling tot in Frankrijk niet verplicht 'langs' de Minister te gaan om toestemming te vragen voor verkoop naar het buitenland. Pleurant No 17 zou in ons stelsel allang naar het buitenland kunnen zijn verkocht.

Het 'openbaar kunstbezit' is min of meer volgelvrij. Het is onduidelijk of de Minister een werk uit het 'openbaar kunstbezit' kan aanwijzen. Heeft een overheidsorgaan het voornemen een werk uit de collectie te vervreemden, dan mag het zelf beslissen of het advies inwint over de vraag of het onmisbaar en onvervangbaar is. Het advies is niet bindend. Tegen het besluit tot vervreemding staat geen beroep op de rechter open.

Of het ten slotte wenseliik is dat de overheid cultureel erfgoed beschermt terwijl zij daarmee tegelijkertijd de eigenaar 'aan de ketting legt', is een politieke vraag.Zoals in de inleiding is gezegd, merkte Thorbecke ooit op dat kunst geen regeringszaak was. Hiermee bedoelde hij niet te zeggen dat de regering kunst moest negeren of de kunsten niet moest steunen. Wat hij wel bedoelde werd duidelijk in een Kamerdebat waarin hij juist voorstellen deed op welke wijze de overheid iets kon betekenen voor de kunst. ${ }^{206}$ Toen het liberale Kamerlid De Brouw hem vanwege deze mooie voorstellen daarna vroeg of kunst nu dan tóch een

206 Te weten reisbeurzen voor jeugdige talenten, zorg voor het onderwijs, openbaarmaking en concentrering van het nationale kunstbezit 'teneinde de kunst bij het publiek bekend te maken en hun die het vermogen om kunstenaar te worden in zich gevoelen tot voorbeeld te dienen' Ten vierde stelde hij voor dat de regering werken van 'levende meesters' kocht, waarbij men er voor moest waken dat er 'een jacht, een speculatie om door de Regering te worden gekocht' zou ontstaan. Oosterbaan-Martinius, noot 4, 87 Handelingen Tweede Kamer 1862-63, 272. 


\section{EEN TREURENDE MONNIK EN EEN ADELAAR}

regeringszaak was geworden, antwoordde Thorbecke:

'De geachte spreker uit Gouda [d.i. De Brouw,] antwoord ik, dat de kunst in mijn ogen evenmin een regeringszaak is als zij dit vroeger was. De kunst is geen regeringszaak, in zoverre dat de Regering geen oordeel, noch enig gezag heeft op het gebied der kunst. Dit is de zin waarin ik gesproken heb.207

Als de overheid zich dan toch enig gezag op het gebied der kunst toemeet en particulier- en openbaar kunstbezit met het oog op het nationale belang wil beschermen, dan geniet de Franse oplossing de voorkeur: streng, maar duidelijk.

F.A.J. van der Ven ${ }^{208}$

ZWOLLE

207 Oosterbaan-Martinius, noot 4, 87. Handelingen Tweede Kamer 1862-63, 272.

208 F.A.J. (Foskea) van der Ven was werkzaam als universitair docent rechtsgeschiedenis aan de Rijksuniversiteit Groningen. 